\title{
O PROCESSO DE ENFRENTAMENTO VIVIDO POR PAIS DE INDIVÍDUOS COM FISSURA LABIOPALATINA, NAS DIFERENTES FASES DO DESENVOLVIMENTO
}

\section{ANA CRISTINA MUSA MINERVINO-PEREIRA}

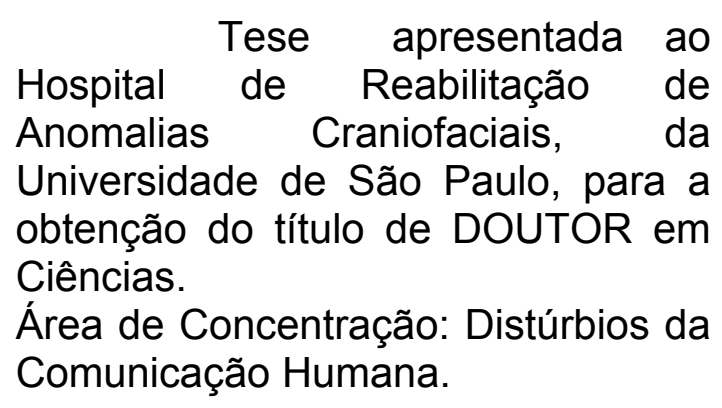


UNIVERSIDADE DE SÃO PAULO

HOSPITAL DE REABILITAÇÃO DE ANOMALIAS CRANIOFACIAIS

\title{
O PROCESSO DE ENFRENTAMENTO VIVIDO POR PAIS DE INDIVÍDUOS COM FISSURA LABIOPALATINA, NAS DIFERENTES FASES DO DESENVOLVIMENTO
}

\author{
ANA CRISTINA MUSA MINERVINO-PEREIRA \\ Orientador: Prof. Dr. José Alberto de Souza Freitas \\ Co-orientadora: Profa. Dra. Olga Maria P. Rolim Rodrigues \\ Tese apresentada ao Hospital \\ de Reabilitação de Anomalias \\ Craniofaciais, da Universidade de São \\ Paulo, para a obtenção do título de \\ DOUTOR em Ciências. \\ Área de Concentração: Distúrbios da \\ Comunicação Humana.
}




\section{UNIVERSIDADE DE SÃO PAULO \\ HOSPITAL DE REABILITAÇÃO DE ANOMALIAS CRANIOFACIAIS}

R. Silvio Marchione, 3-20

Caixa Postal: 620

17043-900 - Bauru - SP - Brasil

Telefone: (0 xx 14) 235-8000

Profa. Dra. Suely Vilela Sampaio - Reitora da USP

Prof. Dr. José Alberto de Souza Freitas - Superintendente do HRAC-USP

Autorizo, exclusivamente para fins acadêmicos e científicos, a reprodução total ou parcial desta tese.

Ana Cristina Musa Minervino-Pereira

Bauru, 5 de dezembro de 2005.

\begin{tabular}{|l} 
Minervino-Pereira, Ana Cristina Musa \\
M662a O processo de enfrentamento vivido por pais de \\
indivíduos com fissura labiopalatina, nas diferentes fases \\
do desenvolvimento. Ana Cristina Musa Minervino-Pereira. \\
Bauru, 2005. \\
143P.;IL.;30CM.. \\
Tese (Doutorado em Ciências - Área de \\
Concentração: Distúrbios da Comunicação Humana) - \\
HRAC-USP \\
Orientador: José Alberto de Souza Freitas \\
Descritores: 1. família 2. enfrentamento \\
3. fissura labiopalatina
\end{tabular}




\section{FOLHA DE APROVAÇÃO}

Tese apresentada e defendida por

\section{ANA CRISTINA MUSA MINERVINO PEREIRA}

e aprovada pela Comissão Julgadora em<smiles>ICCI</smiles>

Prof.(a) Dr.(a):

Instituição:

Prof.(a) Dr.(a):

Instituição:

Prof.(a) Dr.(a):

Instituição:

Prof.(a) Dr.(a):

Instituição:

Prof.(a) Dr.(a):

Instituição:

Profa. Dra. Inge Elly Kiemle Trindade

Presidente da Comissão de Pós-Graduação do HRAC-USP

Data de depósito da tese junto à CPG: ' 


\section{SUMÁRIO}

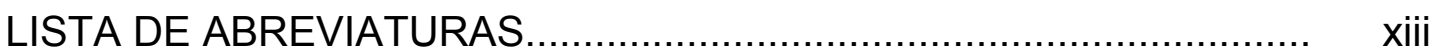

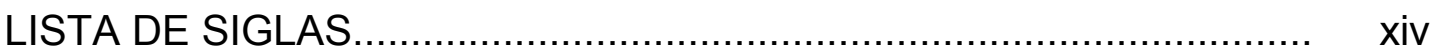

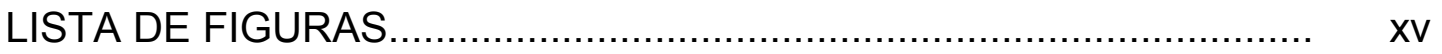

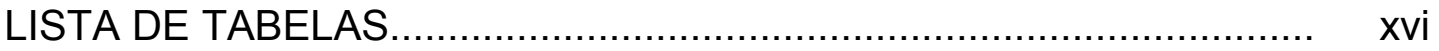

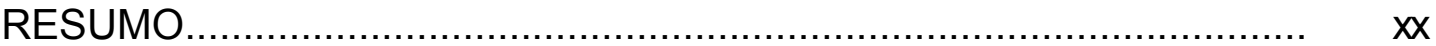

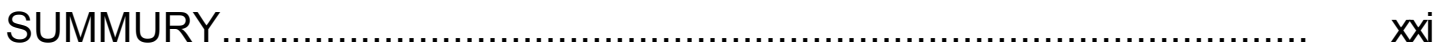

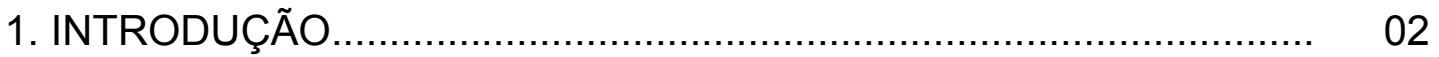

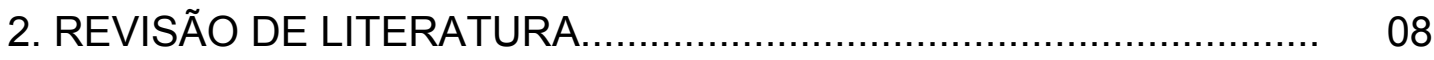

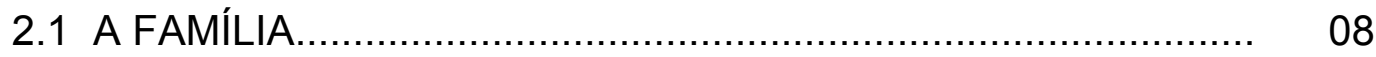

2.2 DESENVOLVIMENTO HUMANO........................................ 11

2.3 AS FISSURAS LABIOPALATINAS ..................................... 17

2.4 REAÇÕES DE FRENTAMENTO.......................................... 22

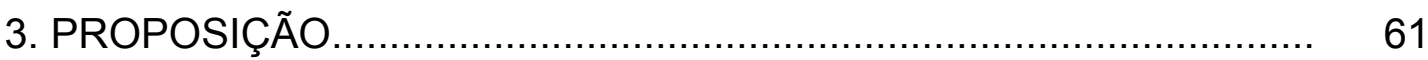

4. MATERIAL E MÉTODO ............................................................ 63

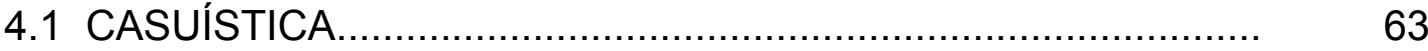

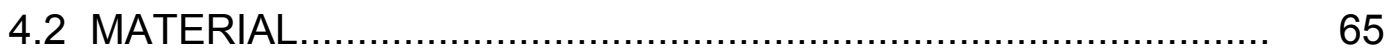

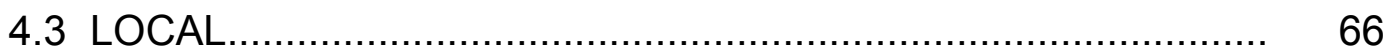

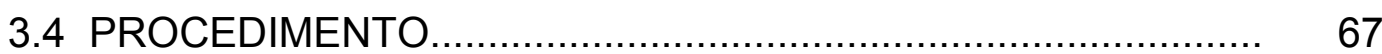

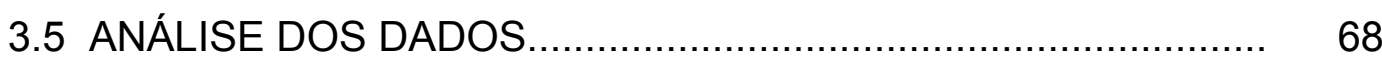

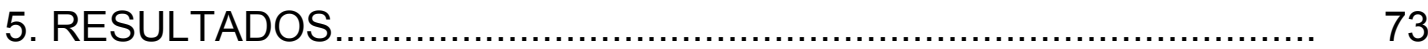


5.1 IDENTIFICAÇÃO DOS PAIS ENTREVISTADOS ........................ 73

5.2 A FISSURA LABIOPALATINA E SUAS IMPLICAÇÕES............. 78

5.3 A INFLUÊNCIA DA FISSURA LABIOPALATINA NA RELAÇÃO

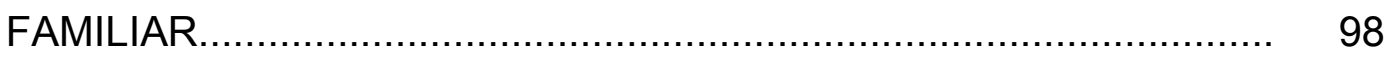

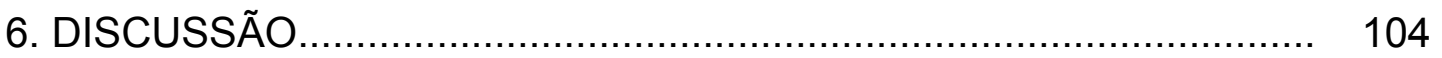

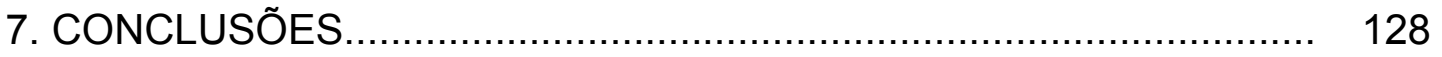

8. REFERÊNCIAS BIBLIOGRÁFICAS.......................................... 132

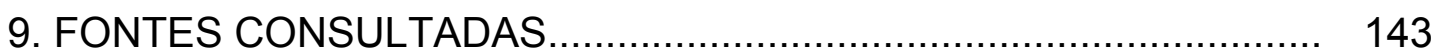


RESUMO

Minervino-Pereira ACM. O processo de enfrentamento vivido por pais de indivíduos com fissura labiopalatina nas diferentes fases do desenvolvimento [tese]. Bauru: Hospital de Reabilitação de Anomalias Craniofaciais, Universidade de São Paulo, 2005.

Objetivo: Descrever e analisar o processo de enfrentamento vivido por pais de indivíduos com fissura labiopalatina, nos seguintes períodos do desenvolvimento humano: por ocasião do nascimento, no início da educação formal e na adolescência.

Modelo: estudo prospectivo que descreveu e comparou três grupos de pais de pacientes com fissura transforame em diferentes etapas do desenvolvimento.

Local: Hospital de Reabilitação de Anomalias Craniofaciais - USP/Bauru

Participantes: 150 pais de pacientes com fissura transforame inciso divididos em três grupos: G1- 50 pais de pacientes com fissura transforame incisivo não operada na faixa etária de zero a dois anos; G2- 50 pais de pacientes com fissura transforame incisivo, na faixa etária de seis a oito anos; G3- 50 pais de pacientes com fissura transforame incisivo, na faixa etária de 12 à 15 anos.

Intervenções: Protocolo de entrevista, abordando questões sobre a identificação dos participantes, os sentimentos experienciados, as atitudes de enfrentamento, redes de apoio utilizadas e a influência da presença do filho na família, nas relações conjugais e nos irmãos.

Variáveis: Diferentes fases do desenvolvimento: ocasião do nascimento, período escolar e adolescência.

Resultados/Conclusões: Os resultados obtidos nesse estudo mostram que há poucas diferenças nas formas de enfrentamento utilizadas por pais de crianças com fissuras transforame nos diferentes períodos de desenvolvimento estudados. Todavia, observou-se que o Grupo 1 está mais suscetível ao momento que estão vivendo, uma vez que apresentam mais sentimentos negativos com relação à condição da sua criança do que os participantes dos demais grupos. Como conseqüência, apresentam estratégias de enfrentamento do tipo negativo e individual, com desdobramentos nos efeitos sobre os outros filhos não fissurados. Os dados obtidos sugerem o investimento de ações junto aos pais, no início da sua história com seu filho fissurado, de forma a possibilitar um relacionamento familiar sadio.

Descritores: família, fissuras labiopalatinas e enfrentamento. 


\section{SUMMARY}

Minervino-Pereira ACM. The coping process experienced by parents of individuals with cleft lip and palate at the different stages of development [thesis]. Bauru: Hospital for Rehabilitation of Craniofacial Anomalies, University of São Paulo, 2005.

Objective: To describe and analyze the coping process experienced by parents of individuals with cleft lip and palate, at the following periods of human development: birth, onset of school education and adolescence.

Model: Retrospective study to describe and compare three groups of parents of patients with complete cleft lip and palate at different stages of development.

Setting: Hospital for Rehabilitation of Craniofacial Anomalies - USP/Bauru

Participants: 150 parents of patients with complete cleft lip and palate divided into three groups: G1 - 50 parents of patients with unoperated complete cleft lip and palate aged 0 to 2 years; G2 - 50 parents of patients with complete cleft lip and palate aged 6 to 8 years; G3- 50 parents of patients with complete cleft lip and palate aged 12 to 15 years.

Interventions: Interview protocol addressing questions on identification of participants, feelings experienced, coping attitudes, supporting networks used and the influence of presence of the child on the family, marital relationships and siblings.

Variables: Different stages of development: birth, school age and adolescence.

Results/Conclusions: The results achieved in the present study revealed few differences in the coping means used by parents of children with complete cleft lip and palate at the different developmental periods investigated. However, Group 1 was more susceptible to the period in which they are living, since they presented more negative feelings as to the condition of their child compared to the other groups. Consequently, they present negative and individual coping strategies, with effects on other non-cleft children. The data obtained suggest that the establishment of actions with the parents, since the onset of their story with their cleft child, would allow a healthy family relationship.

Descriptors: family, cleft lip and palate, coping. 


\section{INTRODUÇÃO.}

O Hospital de Reabilitação de Anomalias Craniofaciais, ligado a Universidade de São Paulo, campus de Bauru, tem desenvolvido, nos últimos 38 anos, um importante trabalho tanto em reabilitação como em pesquisa nas diversas áreas de saúde como Odontologia, Medicina Reparadora, Fonoaudiologia, Serviço Social e Psicologia. Seu atendimento prevê a reabilitação estética, funcional e emocional do portador de anomalias craniofaciais, desde o seu nascimento. Também são previstos por esta Instituição, serviços de genética, visando à prevenção, serviços de apoio aos familiares e serviços de outros profissionais envolvidos com a reabilitação escolar, social e profissional do portador de anomalias craniofaciais.

Entre as anomalias craniofaciais, as mais comuns são as fissuras labiopalatais. A fissura labiopalatina é uma malformação congênita caracterizada pela presença de uma abertura que pode abranger, isoladamente, o lábio e/ou o palato, como a ambos, concomitantemente. Esta malformação e seus desdobramentos atingem não apenas o indivíduo que a apresenta, mas também sua família.

A literatura científica privilegia, sem dúvida, informações pertinentes à fissura labiopalatina, tecendo considerações sobre a sua etiologia, sobre a amplitude de suas extensões e sobre suas implicações bio-psico-sociais. No entanto, quando se fala em fissura labiopalatina, torna-se essencial aprofundarse no sujeito que a experiencia, conhecendo a estreita relação que existe entre a influência desta e a constituição pessoal de quem a apresenta. 
Sabe-se que a personalidade e a saúde psíquica de um indivíduo são profundamente influenciadas a partir de uma relação com os pais, da mesma forma que, a constituição do sujeito, como um ser social se faz, não apenas pelo fato de viver em sociedade, mas, principalmente, pela necessidade da existência do contato com outro homem, para que possa se constituir enquanto pessoa. Este contato humanizador é vivido primordialmente com a família, primeiro grupo a que pertence o indivíduo.

Por meio da família o indivíduo estabelece as primeiras relações afetivas, o aprendizado e o treino de funções e papéis sociais. O contato entre os membros familiares influencia o desenvolvimento da personalidade e os processos de ajustamento social da pessoa.

A criança necessita e depende de seu grupo familiar para realizar seu processo de maturação. A ligação afetiva, considerada aqui como um vínculo subjacente, representada pelo desejo de manter contato com uma pessoa específica, ocorre entre pais e filhos até mesmo antes do nascimento.

As transições próprias de todo o processo de desenvolvimento envolvem mudanças no status, no papel ou nas capacidades físicas do indivìduo, variando de acordo com a constituição de cada família.

No início de desenvolvimento, o indivíduo transita entre uma vida reflexa sob o domínio de estruturas neurológicas primitivas, e o desenvolvimento de capacidades sensório-motoras, de ligações afetivas e início de uma comunicação significante. Na seqüência desse desenvolvimento, que corresponde ao período pré-escolar, consolidam-se os ganhos anteriores, existindo mudanças cognitivas, na linguagem e nas interações sociais bem 
como, a formação de sua identidade sexual. Dos seis anos aos 12 anos, este desenvolvimento fica focado nas aquisições escolares e nas interações sociais mais sólidas. Dos 12 aos 20 anos além das mudanças físicas da puberdade, existe a expansão das operações formais e de novas capacidades sociais.

Cabe ressaltar que a família, no seu status de agente formador e influenciador do sujeito, terá um papel significante em todo o processo de desenvolvimento de um indivíduo.

Considerando que toda e qualquer mudança, por implicar em novas demandas, compromete o equilíbrio do indivíduo e do sistema que está envolvido, pode-se inferir que, qualquer comprometimento pode alterar o processo de desenvolvimento de um indivíduo e interferir de forma significativa nas relações afetivas-sociais estabelecidas entre pais e seus filhos, gerando estresse e quebra de homeostase no sistema familiar.

A abordagem sistêmica considera a família como um sistema complexo e articulado permeado de interdependências e mútuas influências. Desta forma, todo e qualquer acontecimento ou mudança que possa ocorrer a um de seus membros, afetará significativamente os demais.

O processo de reabilitação dos indivíduos portadores de fissura de lábio e/ou palato envolve procedimentos que se iniciam, muitas vezes, por ocasião do nascimento e vão até o início da idade adulta. A presença da fissura labiopalatina bem como dos procedimentos para sua reabilitação são condições agravantes do estresse já experienciado em um processo de desenvolvimento normal. 
Estudos que tratam sobre as formas de elaboração dos agentes estressores e seus comportamentos decorrentes denominam estes, de comportamentos de enfrentamento. Assim, pode-se definir enfrentamento como um conjunto de estratégias utilizadas, diante de uma condição de ameaça, com objetivo adaptativo. Esta condição ocorre em circunstâncias de mudanças drásticas na vida ou em decorrência de problemas, que suscitam emoções ou estados afetivos desconfortáveis exigindo novas formas de comportamento.

A literatura é extensa sobre estudos referentes aos sentimentos experienciados pelos pais na situação de diagnóstico, descrevendo os estágios que são próprios e comuns no processo de aceitação e adaptação para com a criança deficiente. Tais estágios referem-se a crises que exigem do indivíduo diferentes estratégias de enfrentamento.

As fissuras labiopalatinas, por envolverem um processo de reabilitação longo e permeado de seqüelas, tendem a intensificar as crises mais significativas do desenvolvimento humano desde o nascimento até o inicio da idade adulta, exigindo dos pais diferentes estratégias de enfrentamento, apropriadas a cada uma das fases.

Desta forma, a cada novo estágio do desenvolvimento, nova capacidade adaptativa será solicitada tanto do indivíduo como de seus familiares, implicando uma necessidade de avaliação particularizada das estratégias a cada etapa. Esta cuidadosa avaliação pode possibilitar que redes de apoio adequadas sejam oferecidas como instrumentos de suporte e facilitação do 
processo de enfrentamento vivido por pais de indivíduos com fissura labiopalatina. 


\section{REVISÃO DE LITERATURA.}

Antes de revisar-se uma literatura específica, diretamente relacionada com os processos de enfrentamento, teve-se a preocupação de se buscar uma literatura de apoio que pudesse sustentar teoricamente, todas as questões envolvidas com a proposta desse estudo, contextualizando informações necessárias para melhor compreensão deste trabalho. Assim sendo, inicialmente, este capítulo versará sobre a família dentro de uma abordagem sistêmica, considerando sua influência em cada uma das fases do desenvolvimento humano consideradas neste estudo. Serão descritas, também, as fissuras labiopalatinas como uma condição que resulta na reorganização da dinâmica familiar e na elegibilidade de estratégias de enfrentamento, culminando com a descrição de estudos sobre o tema.

2.1 A família.

A família é o primeiro grupo social ao qual o ser humano é inserido. Como unidade nuclear, deve acolher o indivíduo permitindo o desenvolvimento de suas habilidades, experiências, vivências e novas relações humanas. É no ambiente familiar que a pessoa recebe todo apoio afetivo, psicológico, valores morais e éticos, além de outras ferramentas necessárias para seu pleno desenvolvimento físico e mental. A família é a instituição que funciona como a base do convívio social. 
A abordagem sistêmica estuda a família na sua interdependência com outros sistemas sociais e enfoca a inter-relação entre os seus componentes, transferindo a questão individual para o plano relacional (Minuchin e Fishman 1990).

Para Assumpção (1991), a família é o primeiro grupo a que pertence o indivíduo. É neste grupo social natural que se estabelecem as primeiras relações afetivas, o aprendizado e o treino de funções e papéis sociais. 0 contato entre seus membros influencia o desenvolvimento da personalidade e os processos de ajustamento social de uma pessoa.

Para Patterson (1995), a família é o contexto social mais importante, formando e influenciando a saúde e o desenvolvimento da criança. É um grupo de pessoas vivendo juntas ou em contato estreito, que cuidam um do outro e provêem orientação para seus membros dependentes. No entanto, as famílias experimentam muitos tipos de desafios normativos e não normativos durante suas vidas, que podem colocá-las em risco e arruinar suas habilidades de manter a saúde mental do individuo, sob sua responsabilidade, funcionando. $\mathrm{O}$ objetivo para a família é alcançar um equilíbrio entre demandas e capacidades, para que a criança e todos os seus membros, como a unidade familiar em si, experimentem resultados sadios.

Quando as famílias são capazes de desenvolver suas forças e habilidades, elas podem saltar do stress e desafios que elas encaram para eliminar ou minimizar resultados negativos. Isto é o que significa "resiliência familiar": habilidade de funcionar bem e ser competente quando enfrentando situações de stress. Existem muitas maneiras diferentes das famílias 
demonstrarem resiliência. Muitas vezes, a diversidade é na verdade uma fonte de esperança e inspiração para fortalecer as famílias. Apoiar as famílias na descoberta e no desenvolvimento de suas diversas forças e recursos aumenta a base de recurso global para a sociedade e em retorno, a habilidade da sociedade para encontrar as necessidades das famílias, incluindo as necessidades das crianças (Patterson, 1995).

Brito e Dessen (1999) falam da importância da família para a promoção do desenvolvimento da criança, especialmente daquelas que apresentam algum tipo de deficiência, considerando as interações e relações desenvolvidas entre a criança deficiente e sua família. Enfatizam as interações desenvolvidas no microuniverso da família, considerando a sua influência preponderante na evolução das relações futuras da criança. Assim, em seus estudos com crianças surdas são abordados temas relativos à: a) importância das interações e relações sociais para o desenvolvimento e adaptação da criança deficiente; b) o impacto do nascimento de uma criança deficiente no desenvolvimento da família enquanto grupo e, c) a criança surda e suas interações familiares.

Pinho e Kantorski (2004) afirmam ser a família um sistema equilibrado, sendo este equilíbrio mantido pelas regras do seu funcionamento. No processo da evolução do ciclo de vida familiar, cada transição demanda uma reestruturação. Durante esse processo, temos por exemplo, a entrada e saída de membros na família (nascimento, casamento, morte, etc.), o ingresso de um dos membros na escola, a fase de adolescência, entre outros. Todas são etapas que as famílias enfrentam e precisam de reestruturação e reorganização do contexto familiar. Para estes autores, a criança tem como 
referência seu sistema familiar. Ela usa os modelos desenvolvidos no relacionamento com os pais e os irmãos para abordar relacionamentos fora da família, nos grupos de poder e seus pares. O crescimento das crianças precisa ser enfrentado com mudanças na organização da vida cotidiana, processos que envolvem, na melhor das hipóteses, tempo e desconforto.

\subsection{Desenvolvimento humano.}

Para Soifer (1982), a criança é necessitada e dependente de seu grupo familiar para realizar seu processo de maturação, marcado por diferentes fases ou estágios, com transições entre cada um deles.

Bee (1997) coloca que estas transições envolvem mudanças no status, no papel ou nas capacidades físicas do individuo, variando estas de acordo com a constituição de cada família. Para esta autora, do nascimento aos 18 meses de idade, o desenvolvimento do bebe transita entre uma vida reflexa sob o domínio de estruturas neurológicas primitivas até ao desenvolvimento de capacidades sensório-motoras, de ligações afetivas e início de uma comunicação significante. Dos 18 meses aos seis anos, período pré-escolar, consolidam-se os ganhos anteriores. Há grandes mudanças cognitivas na linguagem e nas interações sociais, bem como a formação de sua identidade sexual. Dos seis aos 12 anos, este desenvolvimento fica focado nas aquisições escolares e nas interações sociais mais sólidas. Dos 12 aos 20 anos além das mudanças físicas da puberdade, existe a expansão das operações formais e as novas capacidades sociais. Com todas estas aquisições, por conseqüência, 
tem-se uma nova identidade. Assim, aquele ser que nasceu totalmente dependente e indiferenciado, pelo processo de maturação e pelas oportunidades oferecidas pelo ambiente, torna-se capaz, livre e independente, de posse de sua identidade enquanto pessoa.

Vale ressaltar, resgatando Minuchin e Fishman (1990), que a família é vital para o crescimento dos filhos, constituindo seu modelo de expressão de afeto, de interação, da forma de como lidar com conflitos e dificuldades, de comunicação efetiva, de negociação e principalmente para a construção de seu senso de adaptação.

Para Mussem (1974), o desenvolvimento humano não apresenta momentos de modificações radicais; a evolução é gradual e contínua. Entretanto, em alguns momentos, ocorrerão maiores alterações, como por exemplo, o crescimento físico na infância e na adolescência, mais acentuado e perceptível que na idade adulta, que é um período de maior estabilidade.

Segundo Piletti (1985), a idade não pode ser o único critério na avaliação do grau de desenvolvimento do indivíduo, muito mais importante que a idade são as várias dimensões da maturidade, emocional, social, intelectual e física. Maturidade significa o nível de desenvolvimento em que a pessoa se encontra, em comparação com a maioria das pessoas de sua idade. Os vários tipos de maturidade estão interligados; um não se desenvolve sem que os outros também se desenvolvam.

Para Bee (1997), o desenvolvimento caracteriza-se por um processo de maturação física e psicológica, tanto em nível quantitativo quanto qualitativo, sofrendo influências sócio-econômicas, étnicas, culturais e familiar. Podemos 
observá-lo nos âmbitos motor, perceptivo, intelectual, verbal, afetivo e social. Segundo esta autora, o desenvolvimento se dá em estágios e, cada um exprime uma nova adaptação do indivíduo. O comportamento inteligente reside na capacidade de se adaptar. É importante lembrar que a transição de um estágio para o outro é gradual. No entanto, embora de modo gradual, as principais realizações novas parecem se desenvolver numa seqüência particular, num ritmo aparentemente padronizado, associado com idades que representam alguns marcos do desenvolvimento.

No presente estudo destacam-se três períodos que são considerados significativos no processo de desenvolvimento de um indivíduo: ocasião do nascimento (zero a dois anos), inicio da educação formal (seis a oito anos) e adolescência (12 a 15 anos).

Para Bee (1997), de acordo com a nomenclatura utilizada pela abordagem interacionista de Piaget, a faixa etária do zero aos dois anos de idade, corresponde ao período sensório-motor, assim denominado por ser a atividade intelectual de natureza sensorial e motora. A criança percebe o ambiente e age sobre ele, por isso é essencial a sua estimulação nos primeiros tempos de vida. Nesta fase, ocorre o desenvolvimento da consciência do próprio corpo, diferenciado do restante do mundo físico. É através da “manipulação" (de objetos ou de si próprio) que a criança descobre o mundo. Durante o período sensório-motor, a criança começa a mostrar aspectos rudimentares de intencionalidade e representação interna, mas ainda muito primitivos se comparados com o que se conseguirá depois. A aquisição da 
linguagem acontece num ritmo de desenvolvimento que varia muito de criança para criança.

A criança estabelece sua primeira relação "eu - outro" com a mãe. Até os três primeiros meses a criança encontra-se focada em si mesma. $O$ desenvolvimento social, assim como o desenvolvimento afetivo, constitui-se em grande parte entre zero e dois anos e a partir da relação com os pais e seu grupo social mais reduzido (outros membros da família).

Para Papalia e Oldse Olds (1981), o desenvolvimento da criança neste período é totalmente influenciado pela dinâmica de sua família nuclear, assim, seu bem estar emocional, o desenvolvimento físico, motor e o cognitivo vão estar diretamente relacionados a este ambiente familiar restrito e às relações afetivas estabelecidas com os que estão à sua volta.

$\mathrm{Na}$ faixa etária dos seis aos oito anos de idade, a criança se encontra, segundo uma terminologia piagetiana, no período das operações concretas, que se caracteriza pelo desenvolvimento do pensamento lógico sobre coisas concretas e a superação do egocentrismo da linguagem.

Para Papalia e Olds (1981), este é um período de consolidação e não de novidade. Apesar de, neste momento, interagir melhor com outras crianças, seus pais são extremamente importantes para a criança. A maneira como sentem e/ou agem influencia a sua auto-estima, o seu desenvolvimento acadêmico e a sua criatividade. Para esta autora a escola é o foco da vida da criança.

A escolarização, segundo Bee (1986) é a maior força neste estágio. A criança enfrenta agora a necessidade de conseguir a aprovação social, através da 
produtividade (aprendizagem diversificada). É sua tarefa, também, desenvolver um repertório de habilidades sociais. Quando a criança, neste momento, não é capaz de desenvolver as capacidades esperadas, corre o risco de comprometer-se com sentimentos de inferioridade. Sua ida para a escola significa a primeira separação da família por um período prolongado, que the impõe uma necessidade de ajustamento a um grupo maior de crianças e adultos, o que envolve sua adaptação a um novo conjunto de regras.

O fato de a criança começar a experimentar mais diretamente o impacto de ambientes externos à família, em especial da escola e da comunidade, a aculturação ainda continua a se fazer principalmente através da família (Lewis e Volkman, 1993).

Quanto à adolescência, pode-se afirmar, que esta é uma extraordinária etapa na vida de todas as pessoas. É nela que a pessoa constrói a sua identidade e define a sua personalidade. Nesse processo, manifesta-se uma crise, na qual se reformulam os valores adquiridos na infância e se assimila numa nova estrutura mais madura. A adolescência é uma época de imaturidade em busca de maturidade. No adolescente, nada é estável nem definitivo, porque se encontra numa época de transição (Aberastury e Knobel 1981).

A adolescência é o período no qual uma criança se transforma em adulto. Não se trata apenas de uma mudança na altura e no peso, nas capacidades mentais e na força física, mas também de uma grande mudança na forma de ser, de uma evolução da personalidade. As características mais comuns deste período referem-se ao despertar do próprio "eu"; às crises de 
crescimento físico, psíquico e maturação sexual; ao desequilíbrio nas emoções, que se reflete na sensibilidade exagerada e na irritabilidade de caráter; à "não sintonia" com o mundo dos adultos e ao refugio no isolamento ou no grupo de companheiros e/ou amigos. Do despertar do "eu" passa-se à descoberta consciente do "eu" e da própria intimidade.

Neste momento aparece a necessidade de amar. A timidez e o medo da opinião alheia, motivados pela desconfiança em si mesmo e nos outros, são características desta fase, assim como: a experiência do conflito interior ou da personalidade; comportamentos negativos de inconformismo e agressividade para com os outros, causados pela frustração de não poderem valer-se por si mesmos (Graña 1993).

Todavia, qualquer comprometimento pode alterar o processo de desenvolvimento de um individuo, seja ele em qualquer de suas fases, interferindo de forma significativa nas relações afetivas-sociais estabelecidas entre pessoas não-deficientes e pessoas deficientes, entre pais e filhos comprometidos.

2.3 As fissuras labiopalatinas.

As fissuras labiopalatinas são malformações congênitas que desenvolvem, de maneira disforme, a estrutura da face durante o período embrionário e o início do período fetal, sendo representadas, clinicamente, pela ausência de fechamento do lábio, palato ou ambos. A fissura que envolve o lábio é denominada de pré-forame incisivo; a de palato, pós-forame incisivo e a fissura que envolve ambas as estruturas é denominada de transforame incisivo 
(Spina et al.1972). Uma fissura labial pode ou não estar associada a uma fissura de palato, da mesma maneira que, uma fissura palatina pode ou não estar associada a uma fissura de lábio (Garcia 1997).

Embriologicamente, origina-se da ausência de coalescência entre os processos faciais embrionários e os processos palatinos, num período que correspondente da oitava semana (fase de finalização da formação facial) à décima segunda semana, fase de conclusão dos processos palatinos (Capelozza Filho e Silva Filho 1992; Modolin e Cerqueira 1997).

Fraser (1970) citou como fatores etiológicos as substâncias tóxicas exógenas provocadas por medicamentos, defensivos agrícolas (agrotóxicos e herbicidas) e a consangüinidade dos pais. Tecendo ainda considerações sobre a etiologia, pode-se ressaltar a não existência de um fator causal específico, mas sim, de possíveis agentes, que podem ser agrupados em duas categorias: fatores genético e ambiental. O fator genético corresponde apenas a $30 \%$ dos casos, enquanto que o restante é atribuído a qualquer fator adverso ao meio uterino durante o período embrionário: infecções viróticas, epilepsia, drogas anticonvulsivas, deficiência nutricional, irradiação ionizante, estresse emocional, fumo, alcoolismo e idade dos pais na concepção. A teoria mais atual é a de causa multifatorial, que considera a presença da fissura de lábio e/ou palato resultado das interações entre as variantes genéticas e os fatores teratogênicos extragenéticos (Capelozza Filho e Silva Filho 1992; Modolin e Cerqueira 1997).

Considerando o aspecto hereditário, a fissura labiopalatina pode ocorrer com $0,1 \%$ de chance quando os pais não a apresentam, com $2 \%$ de 
chance quando um dos pais é portador, com $4,5 \%$ de chance quando os pais não são portadores, mas já tem um filho fissurado e $15 \%$ de chance quando um dos pais e um filho são portadores (Souza-Freitas 1974).

As fissuras labiopalatinas acometem todos os grupos raciais e étnicos, independentemente de sexo e classe sócio-econômica. Entre as raças, a amarela é a mais susceptível à sua ocorrência: 1:373, segundo Neel (1958) e 1:498, conforme Natsume (1984). Para a raça negra, o nível de ocorrência é o mais baixo, 1:2.070 (Iregbulem 1982). A raça branca fica com valor intermediário, ou seja, 1:700 (Souza-Freitas 1974; Johnson 1987). Em Bauru, as fissuras labiopalatinas acometem, em média, um indivíduo para cada 650 nascimentos (Nagen Filho 1968).

Quanto ao sexo, a maior freqüência de fissuras labiopalatinas com envolvimento labial é nos sujeitos do sexo masculino, enquanto que as fissuras isoladas de palato têm maior freqüência no sexo feminino (Fraser 1960, Greene 1964, 1968, Åbyholm 1978 e Modolin e Cerqueira 1997.

Silva Filho (1992) afirmou a necessidade de um sistema de classificação das fissuras labiopalatinas que abranja uma terminologia simples, clara e precisa; uma facilidade para comunicação entre os profissionais de diferentes especialidades que formam a equipe reabilitadora do portador de fissura labiopalatina e uma linguagem universal que permita a análise e compreensão dos dados de diferentes centros de reabilitação, sem a confusão de critérios desconhecidos.

Dentre a diversidade de sistemas de classificação existentes, a de Spina et al. (1972) é a utilizada pelo Hospital de Reabilitação de Anomalias 
Craniofaciais (HRAC). Calcada nos padrões embriológicos de fusão de processos faciais embrionários, essa classificação toma como ponto de referência o forame incisivo, ponto de junção na formação de toda a região labiopalatina. $\mathrm{O}$ autor classificou a fissura em quatro grupos:

O Grupo I compreende a fissura pré-forame incisivo, a qual se localiza à frente do forame incisivo, podendo abranger lábio e o rebordo alveolar, sendo essa, sub-classificada em completa e incompleta e de acordo com o lado envolvido, em unilateral, bilateral ou mediana.

O Grupo II refere-se à fissura transforame incisivo, subentendendo-se fissuras totais, que rompem a maxila em toda sua extensão, desde o lábio até a úvula, podendo ser unilaterais ou bilaterais. Esse tipo de fissura tem uma freqüência predominante no sexo masculino e no lado esquerdo.

O Grupo III corresponde ao tipo de fissura pós-forame incisivo, onde residem as fissuras isoladas de palato, localizadas posteriormente ao forame incisivo. Essa fissura pode ter vários graus de extensão, sendo que sua gravidade segue uma progressão de envolvimento crescente, da região mais posterior da úvula em direção ao forame incisivo, podendo ser completa, caso atinja o forame incisivo ou incompleta quando esse não for atingido.

O Grupo IV diz respeito às fissuras raras da face, no qual fazem parte as fissuras que envolvem estruturas faciais outras, além do lábio e/ou palato.

Em relação à ocorrência do tipo de fissura, $25 \%$ são pré-forame, $25 \%$ pós-forame e $50 \%$ são transforame. Dentre esse último tipo, destaca-se a transforame incisivo unilateral do lado esquerdo, como sendo a de maior incidência (Åbyholm 1978). 
$\mathrm{Na}$ condição de não se ter evitado ou prevenido a existência de fissuras labiopalatinas, essa malformação e todas as suas inerências são assistidas oportunamente por uma equipe interdisciplinar especializada, instituída de preferência, logo após o nascimento. No Hospital de Reabilitação de Anomalias Craniofaciais (HRAC) da Universidade de São Paulo, local de realização desse trabalho, profissionais das áreas de enfermagem, nutrição, cirurgia plástica, medicina, fisioterapia, odontologia, fonoaudiologia, psicologia, serviço social e pedagogia unem esforços com uma filosofia de tratamento global visando uma reabilitação morfológica, funcional e psicossocial do paciente (Capelozza Filho e Silva Filho 1992).

Em decorrência dos comprometimentos da fissura labiopalatina, há necessidade de correções cirúrgicas a fim de minimizar os problemas conseqüentes da mesma. No que concerne à fissura labial, a queiloplastia, preocupa-se não apenas com a reconstrução funcional do lábio, mas, principalmente, com uma restituição da harmonia facial. Para Bertier et al. (1996) e Gomes e Mélega (1997), a criança, a partir do terceiro mês de vida, tem condições de se submeter à cirurgia reparadora, desde que apresente condições satisfatórias para a anestesia geral.

Segundo Carreirão e Silva (1996) e Gomes e Mélega (1997), considerando-se o estado geral do paciente e as condições de oclusão velofaríngea, a idade ideal para o fechamento da fissura palatina (palatoplastia) é aos dezoito meses de idade, visando-se principalmente, o desenvolvimento dos aspectos funcionais e a prevenção dos acometimentos referentes aos 
mesmos. No entanto, é importante salientar que, atualmente, no HRAC a idade adotada para a realização da palatoplastia é a de doze meses.

Souza-Freitas (1974) afirmou que as malformações congênitas do lábio e do palato provocam em seu portador graves problemas funcionais, estéticos e psíquicos. Dentre os problemas funcionais e físicos estão as dificuldades relacionadas à mastigação, à deglutição, à audição, à respiração, aos comprometimentos da arcada dentária, à propensão a infecções otorrinolaringológicas e, ainda, no caso da fissura que envolva o palato, à aprendizagem da fala apresentando uma voz marcadamente nasalizada.

Também, é comum nos portadores de fissura labiopalatina, a presença de distúrbios articulatórios simples (omissão, substituição e/ou distorção dos fonemas da língua) e/ou distúrbios articulatórios compensatórios (golpe de glote, plosiva faríngea, plosiva dorso médio palatal, fricativa faríngea, fricativa faríngea alta, fricativa faríngea baixa e fricativa posterior). Nesses, há uma posteriorização do ponto articulatório numa tentativa que esse sujeito faz de falar o mais próximo possível da fala dos sujeitos sem fissura labiopalatina (Amaral e Genaro 1996 e Bradley 1997).

A partir das implicações físicas e funcionais da fissura labiopalatina, surgem outras ainda mais fortes na vida de seu portador: as psicossociais. Os fatores relacionados a uma dificuldade de comunicação eficiente e a uma condição de aparência física comprometida, tornam o indivíduo portador de fissura labiopalatina, alvo de adjetivos depreciativos ao apresentar-se num grupo social (Pereira e Mota 1997). 
De posse de todas estas implicações relacionadas à condição de fissura labiopalatina, pode-se apreender com maior lucidez as informações pertinentes às reações dos pais frente ao nascimento e à convivência com um filho(a) fissurado(a).

2.4 Reações e enfrentamento.

Nos últimos anos, o tema enfrentamento ou coping, como é denominado na língua inglesa, vem chamando a atenção de pesquisadores e profissionais de saúde, comprometidos com a adaptação psicossocial do ser humano diante da adversidade. Toda pessoa, ao longo da vida, se depara com uma série de situações problemáticas que podem abranger desde grandes crises, tais como uma doença grave e suas conseqüências, até pequenas dificuldades encontradas no dia-a-dia de todo ser humano. A natureza e a intensidade do impacto, acarretado na vida da pessoa por tais situações, dependem da relação entre a situação problemática e o sujeito que a experiência, dentro do contexto sociocultural no qual este se insere.

Enfrentamento ou coping é um termo usado para descrever qualquer tipo de ação ou comportamento apresentado para lidar com um perigo ou um inimigo, em situações ameaçadoras, problemáticas ou limitadoras.

Lazarus (1966) definiu o enfrentamento como um conjunto de estratégias para lidar com uma ameaça iminente.

Em 1970, Lipowski definiu o enfrentamento como toda atividade cognitiva e motora que uma pessoa doente usa para preservar sua integridade 
física e psíquica, numa tentativa de compensar as limitações impostas por deficiências irreversíveis.

Para White (1974), o enfrentamento ocorre quando a pessoa enfrenta mudanças drásticas de vida ou problemas que exigem novas formas de comportamento e provocam emoções ou estados afetivos desconfortáveis, tais como ansiedade, desespero, culpa, vergonha, luto, quando o alívio destes estados exige adaptação.

Mechanic (1976) referiu-se ao enfrentamento como um comportamento instrumental que demonstra a capacidade da pessoa para resolver problemas decorrentes das exigências e dos objetivos de sua vida, envolvendo, portanto, o uso de habilidades diversas, técnicas e conhecimentos que a pessoa venha adquirindo ao longo de sua vida.

Em 1984, Lazarus e Folkman definiram o enfrentamento como o processo para lidar com exigências externas ou internas, que são avaliadas como sobrecarregando ou excedendo os recursos da pessoa. Para estes autores o termo processo implica numa série de transações entre a pessoa que possui um conjunto de recursos disponíveis, valores e compromissos e um contexto ambiental com suas exigências e restrições particulares. Portanto, o enfrentamento não é uma única ação ou resposta dada por uma pessoa em um determinado momento, mas, um conjunto de respostas recíprocas, ocorrendo ao longo de um período de tempo, durante o qual, o ambiente e a pessoa se influenciam mutuamente. O emprego do termo "lidar" ao invés dos termos "dominar" ou "superar" é mais adequado, uma vez que muitos problemas não 
podem ser superados, mas apenas tolerados, aceitos, ou redefinidos para facilitar a adaptação da pessoa.

Para Gimenes (1997), o conceito de enfrentamento tem recebido, na Psicologia, um papel central no que se refere à adaptação do ser humano nas suas diferentes fases do desenvolvimento.

Para Pedrolo (2002), o enfrentamento emerge como estratégia para lidar com uma situação estressante, necessário para manter os desafios e afastar as ameaças, como também, reduzir ou eliminar a fonte de estresse, favorecendo a adaptação psicológica do indivíduo ou da família.

Tais definições propõem que apenas ações não automáticas e não utilizadas rotineiramente sejam mencionadas sob o termo enfrentamento, portanto, ficando claro que o enfrentamento ocorre apenas quando a pessoa não pode se comportar diante das exigências da sua vida da mesma forma como vinha fazendo anteriormente, precisando apresentar novos comportamentos que representam estratégias de enfrentamento.

A perspectiva de se considerar o enfrentamento como um processo nos permite dizer que um mesmo indivíduo pode apresentar diferentes estratégias de enfrentamento diante de um contexto particular. Ou ainda, que um mesmo indivíduo pode apresentar estratégias de enfrentamento diversas, compondo estratégias distintas diante de situações estressantes, cujos temas são aparentemente semelhantes.

Lazarus e Folkman (1984) afirma que, quando um indivíduo enfrenta uma enfermidade física importante ou uma incapacidade, sua ou de familiares, procederá de acordo com uma série de etapas de enfrentamento iniciadas a 
partir do momento em que é informado de seu estado. Para este autor, a primeira etapa é de choque, que aparece principalmente quando a crise ocorre sem aviso prévio. Esta etapa se manifesta por um sentimento de distanciamento e, em algumas vezes, por uma surpreendente lucidez e eficácia no pensamento e na ação. A esta se segue uma fase de encontro, um período extremamente intenso no qual o indivíduo pode experimentar desesperança, pânico e desorganização. A terceira fase é a de retirada que parece corresponder à negação. A fase de retirada vai sendo pouco a pouco abandonada em favor de uma crescente comprovação da realidade. O processo de enfrentamento inclui um contínuo ir e vir nestas diferentes fases, representando um importante recurso natural para evitar o desmoronamento. Da mesma forma que pode ser visto como um recurso necessário para o amadurecimento psicológico proporcionando uma renovação do valor pessoal, uma maior sensação de satisfação e uma diminuição da ansiedade.

O enfrentamento tem como função muito mais que a resolução de um problema, mas tem a ver com o objetivo que antecede cada estratégia. A definição de funções de enfrentamento depende do marco teórico sobre o qual se conceituaria o enfrentamento e do contexto no qual é analisado. Assim sendo, sua função pode ser uma forma de tomar decisões, buscando a evolução da informação (White,1974); de reduzir a tensão, devolvendo o equilíbrio (Janis e Mann, 1977); de resolver problemas (Cerqueira, 2000); como também, funções de enfrentamento que pertencem a contexto específicos, como saúde/doença, crises políticas, bem estar e outros. 
Folkman e Lazarus (1980) e Cerqueira (2000) fazem uma diferenciação no que se refere às funções do enfrentamento considerada de extrema importância: a diferença que há entre o enfrentamento dirigido a manipular ou alterar o problema e o enfrentamento dirigido à regulação da resposta emocional a que o problema dá lugar. Desta forma temos: a) enfrentamento dirigido à emoção e, b) enfrentamento dirigido ao problema.

No enfrentamento dirigido à emoção estão incluídas estratégias como a evitação, a minimização, o distanciamento, a atenção seletiva às comparações positivas e a relevância de valores positivos em acontecimentos negativos. Existem, também, as estratégias que aumentam o grau do transtorno emocional, pois algumas pessoas necessitam sentirem-se verdadeiramente mal antes de começarem a se sentir melhores. Certas formas cognitivas de enfrentamento dirigido à emoção modificam a forma de viver a situação, sem mudá-las objetivamente. Estas estratégias equivalem a uma reavaliação, utilizando-se de manobras para se diminuir a ameaça ("...existem coisas mais importantes para se preocupar..."). São as reavaliações defensivas que implicam na distorção da relação com a realidade. Outras estratégias de enfrentamento dirigidas à emoção não trocam diretamente o significado do acontecimento como fazem as reavaliações cognitivas. São estratégias de conduta como: iniciar um exercício físico para esquecer-se do problema, meditar, buscar apoio emocional, entre tantas.

Os processos dirigidos à emoção podem trocar o significado de uma situação estressante sem distorcer a realidade, levando-se em conta a autodecepção como fenômeno sempre possível neste tipo de enfrentamento. 
Utiliza-se o enfrentamento dirigido à emoção, para conservar a esperança e o otimismo, para negar tanto o fato como suas implicações, para não ter que aceitar o pior, para atuar como se o ocorrido não fosse importante. Estes processos conduzem à uma interpretação de auto-decepção ou de distorção da realidade. A auto-decepção eficaz existe sem o conhecimento do sujeito, o que coincide com a afirmação de que os processos cognitivos de avaliação não são conscientes. O processo inconsciente pode ser inferido a partir de três contradições: contradição entre o que se diz e o que se faz, entre o que se diz em dois momentos distintos e entre o que se diz e o que se pensa. Para Cerqueira (2000), as estratégias são focalizadas na emoção quando a condição é avaliada como imutável.

No enfrentamento dirigido ao problema as estratégias utilizadas são parecidas com as utilizadas para a resolução de problemas. Geralmente incluem a definição do mesmo, a busca de soluções alternativas e a consideração de todas as alternativas com base no custo/benefício. O enfrentamento dirigido ao problema engloba um conjunto de estratégias mais amplas: a resolução do problema implica em um objetivo, um processo analítico dirigido principalmente ao ambiente, incluindo também estratégias que fazem referência ao interior do sujeito. No primeiro grupo se encontram as estratégias dirigidas à modificação das pressões ambientais, os obstáculos, os recursos, os procedimentos, etc. No segundo grupo se incluem as estratégias encarregadas das trocas motivacionais ou cognitivas, como a variação do nível de aspirações, a busca de canais distintos de gratificação, o desenvolvimento de novas pautas de condutas e o aprendizado de recursos e procedimentos 
novos (Folkman e Lazarus 1980; Cerqueira 2000). Para Savoia (1999), o enfrentamento centrado no problema e na emoção influenciam-se mutuamente em todas as situações estressantes. As pessoas utilizam ambas as formas de enfrentamento, o que pode impedir ou facilitar a manifestação de uma ou outra forma.

É impossível catalogar todos os recursos que as pessoas apresentam para enfrentar as demandas da vida, portanto estes recursos serão identificados em categorias e considerados aqueles que se referem principalmente ao indivíduo, como recursos físicos e recursos psicológicos. Em termos de recursos físicos a saúde e a energia certamente facilitam o enfrentamento. O importante papel desempenhado pelo bem estar físico se evidencia quando se tem que resistir a problemas e interações estressantes que exigem uma motivação importante. Entre os recursos psicológicos estão as crenças positivas, que podem ser gerais e específicas, servindo de base para a esperança e que favorecem o enfrentamento nas condições mais adversas. No entanto, a esperança existirá somente quando tais crenças tragam a possibilidade ou, pelo menos a probabilidade de um resultado possível. Desta forma, uma crença pode conduzir a uma desesperança que por sua vez diminui o enfrentamento dirigido ao problema. De forma similar, uma crença negativa sobre a própria capacidade de exercer controle sobre uma situação, ou sobre a eficácia de uma determinada estratégia, pode diminuir a capacidade de enfrentar os problemas. As crenças que fazem referencia ao "locus" do controle (interno ou externo), são aquelas que recebem maior atenção. Acredita-se que uma crença geral sobre um locus de controle interno produz maior atividade e 
persistência no enfrentamento. Para Strickland (1978), se o locus de controle é interno, predominam as estratégias dirigidas ao problema e se o locus é externo, predominam as estratégias dirigidas à emoção.

Savoia (1999) coloca que a forma pela qual uma pessoa usa o enfrentamento está determinada por seus recursos pessoais, os quais incluem saúde e energia, crenças existenciais, habilidades de solução de problemas, habilidades sociais, suporte social e por recursos materiais. O enfrentamento é também determinado por variáveis que diminuem o uso dos recursos pessoais, Podem ser de natureza pessoal, incluindo valores e crenças culturais que prescrevem certas formas de déficits de comportamentos. Podem ser ambientais, incluindo demandas que competem com os recursos pessoais e/ou agências como instituições que impedem os esforços do enfrentamento. Strickland (1978) cita alguns estudos, os quais indicam que as pessoas que acreditam que os resultados dependem de suas próprias condutas, enfrentam de forma distinta os problemas relacionados com a saúde, daquelas que consideram o resultado como fruto do azar, da causalidade, do destino e de forças que se encontram fora do controle pessoal.

Concordando com os autores acima citados, Lazarus e Folkman (1984) consideram que as estratégias de enfrentamento dependem de recursos materiais, de valores e crenças, de habilidades sociais, de apoio social e de recursos materiais da pessoa. As habilidades sociais são importantes recursos de enfrentamento, devido à importância da atividade social na adaptação humana. Estas habilidades se referem à capacidade de comunicar-se e atuar com os demais de uma forma socialmente adequada e efetiva. Estes tipos de 
habilidades facilitam a resolução de problemas em conjunto com outras pessoas, aumentando a capacidade de atrair apoio e cooperação, possibilitando ao indivíduo um controle mais amplo sobre as interações sociais e um manejo melhor dos problemas cotidianos. O apoio social (o fato de se ter alguém de quem se receber apoio emocional, informativo e qualquer outro tipo) é um rico recurso de enfrentamento nas situações de estresse. Quanto aos recursos materiais estão o dinheiro, os bens e serviços que podem ser adquiridos por ele. Os recursos econômicos aumentam de forma importante as opções de enfrentamento na maioria de situações estressantes, proporcionando um acesso mais fácil e efetivo à assistência legal, médica, financeira ou de qualquer outro tipo. $O$ fato de se ter dinheiro, mesmo que não se use, pode reduzir a vulnerabilidade do indivíduo à ameaça e desta forma facilitar o enfrentamento efetivo.

Para Gimenes (2000), a seleção das respostas de enfrentamento é influenciada pelas exigências situacionais, limitações, recursos disponíveis e por fatores pessoais. Todos estes aspectos interagem para delinear o processo de avaliação cognitivo que, por sua vez, influencia a escolha das estratégias de enfrentamento que são utilizadas para lidar com o problema.

2.5 Estudos sobre enfrentamento.

Uma extensa literatura propondo-se a analisar o processo de enfrentamento, vivido por pais de crianças comprometidas, tem sido desenvolvida, sobretudo a partir da década de 1970 (Bradbury e Hewison 
1964; Emmel e Matsukura 1989, Cariola e Ferreira de Sá 1991; Petean e Pina Neto 1998; Carvalho e Tavano 2000; Shaver 1993, Patterson 1995, Davis et al. 1998, entre outros).

Dentro desta literatura específica, a primeira citação, refere-se ao estudo de Bradbury e Hewison (1964), que afirmaram a necessidade dos pais de ajustarem-se à perda do 'filho perfeito' para aceitar o seu bebê nascido com uma visível desfiguração. Os autores estudaram dois grupos formados por pais de crianças: um com fissura congênita de palato e outro com defeito congênito da mão. Não foi constada nenhuma diferença significativa entre os dois grupos avaliados nos termos de seu ajuste total, mas houve diferenças individuais no ajuste, que não se relacionaram à severidade ou ao tipo de anomalia. A única variável significativa encontrada para relacionar-se ao ajuste foi o suporte da família. Ficou demonstrado também, que a ligação estabelecida entre os pais e seus filhos, na infância, influenciará a criança em seus futuros relacionamentos. A habilidade dos pais em aceitar suas crianças de uma forma afetiva, indica ser de importância crucial para o seu desenvolvimento psicossocial futuro.

Emmel e Matsukura, em 1989, desenvolveram trabalho que teve por objetivo minimizar os sentimentos negativos de mães de crianças portadoras de desordens no desenvolvimento, no que diz respeito ao seu autoconceito e a conseqüente interação com seu filho, por meio da utilização de atividades planejadas para serem conduzidas com grupos. Quatro mães, com idades variando entre 32 e 38 anos, compuseram a amostra de sujeitos que participaram de dez sessões de atividades de terapia ocupacional em uma 
clínica de uma universidade pública. Os resultados indicaram mudanças paulatinas nas atividades das mães em relação ao grupo, a si próprias e aos filhos. Aos poucos, observou-se o aumento da consciência de sua situação, a busca de medidas para solucionar suas dificuldades e a tomada de decisões fora da situação grupal. O trabalho reafirmou a importância da utilização de atividades como um recurso de enfrentamento e instrumento do processo terapêutico.

Cariola e Ferreira de Sá, em artigo de 1991, realizaram estudos onde procuraram avaliar as conseqüências psicológicas ou choque emocional dos pais, logo após o nascimento de uma criança com malformação congênita na face. Os dados analisados foram obtidos através de entrevista com os pais durante o primeiro comparecimento ao Hospital de Pesquisa e Reabilitação de Lesões Labiopalatais da USP. A amostra foi composta de 82 casais, pais de pacientes com até seis meses de idade, pertencentes a diferentes níveis socioeconômicos. Os dados mais significativos para este trabalho foram: 1) o choque emocional foi constatado em $72,5 \%$ das mães e $67,7 \%$ dos pais; 2 ) receberam orientação imediata e adequada $87 \%$ dos casais; 3) a principal preocupação com o recém nascido era com a alimentação (56,4\%); 4) entre as variáveis que colaboraram para que a criança fosse aceita pelos pais estavam a obtenção do aleitamento e da alimentação adequada $(22,4 \%)$ e o fato da criança se desenvolver dentro dos padrões da normalidade $(33,8 \%) ; 5)$ o relacionamento do casal após o nascimento do paciente: permaneceu com estava $(49,9 \%)$, melhorou (37\%) ou piorou $(12,9 \%)$. As autoras concluem que o "choque emocional" sofrido pelos pais é bastante intenso e freqüente e o 
atendimento psicológico torna-se indispensável, não só para amenizar a ansiedade e sofrimento presentes, mas também para evitar dificuldades futuras, promovendo assim o bem estar de todos.

Estes dados confirmam Shaver (1993), que reconhece que as famílias são fortemente afetadas pelo nascimento de filhos comprometidos. Muitos pais encaram a deformidade de um filho como um golpe à sua auto-estima e podem sentir que criaram alguma coisa má. As reações dos pais variam em intensidade e duração, porém, a maioria dos pais reage com uma variedade de sentimentos, variando de choque, negação, luto, culpa, esperança, vergonha e rejeição, a aceitação. Muitos pais experimentam a primeira reação como um choque. Outros pais são capazes de negar a deficiência por tempo muito longo, se a criança não parecer diferente. Outra reação comum aos pais é atravessar um período de amargura e luto. Muitos pais de crianças deficientes possuem sentimentos de culpa consideráveis em relação ao filho. Sentem que fizeram alguma coisa que foi a causa do filho se tornar deficiente e que estão sendo castigados. Outros pais ficam envergonhados e embaraçados com 0 desenvolvimento deficiente do filho. Frequentemente se sentem, e são, isolados dos amigos e parentes. Portanto, o autor conclui que, quando os pais têm à frente uma criança com deformidade física ou com retardamento severo, podem não ser capazes de aceitar esse filho ou suas necessidades. Muitas vezes a rejeição dos pais transforma-se em superproteção. Entretanto, há um tempo em que a aceitação vem. Alguns fatores podem facilitar isso. Em primeiro lugar, os pais precisam aceitar que a criança tem uma deficiência e, a seguir, aceitar a criança como ela é. Os pais precisam ser capazes de 
reconhecer o filho como uma pessoa com sentimentos, forças e necessidades, ter metas realistas para ele e se orgulharem dele.

Davis et al.. (1998) investigaram o nível de estresse, as estratégias de enfrentamento e o ajuste materno de mães de crianças com defeitos congênitos do coração. Participaram da pesquisa, 52 mães de crianças recrutadas de um centro médico de uma universidade. As medidas incluíram avaliações do estresse, das expectativas dos pais, dos métodos de enfrentamento e do funcionamento familiar. $\mathrm{O}$ ajuste maternal avaliado estava associado com os níveis elevados de estresse diário e de técnicas paliativas de enfrentamento, não estando associadas, significativamente, com a severidade do defeito cardíaco. Os achados estão de acordo com os de outras pesquisas em outras populações de doentes crônicos, que sugerem uma associação entre o estresse, o enfrentamento e o ajuste materno.

O trabalho de Petean e Pina Neto (1998) procurou conhecer, junto aos pais de crianças portadores de deficiência e/ou anomalias genéticas, qual o impacto causado pela notícia, suas reações e sentimentos. Participaram desde estudo 10 famílias, que foram encaminhadas à um Ambulatório de Genética Médica de um Hospital de uma Universidade Pública, para diagnóstico e orientação. Os relatos mostraram que o impacto emocional da notícia é grande, desencadeando reações diversas, entre elas choque e agressividade. Culpa, negação e raiva são alguns dos sentimentos relatados pelos pais. A notícia é dada quase sempre de maneira inadequada, dificultando a compreensão do diagnóstico. Pode-se concluir que, independentemente do quadro clínico, os pais sofrem um impacto com a notícia de que seu filho é portador de deficiência 
e/ou anomalia genética. O processo de sofrimento é agudo, passando os pais por um período de enlutamento pela perda do filho esperado.

Turner et al.. (1998) estudaram as influências da dinâmica familiar no desenvolvimento social e reabilitação de pacientes com fissura labiopalatina. Problemas psicológicos, tais como a diminuição da auto-estima e dificuldades com a interação social que também são vivenciadas por esses indivíduos. Levando em conta os fatores psicológicos na reabilitação de indivíduos afetados por fissuras labiopalatinas, esses autores consideraram o ambiente familiar como sendo de grande importância, ressaltando que as atitudes, as expectativas e o grau de suporte que os pais oferecem à criança vão influenciar a percepção dessa sobre o prejuízo causado pela fissura labiopalatina. A percepção de sua atratividade facial e de sua habilidade para comunicação verbal tem uma influência importante sobre o bem-estar psicológico do indivíduo. Como nós nos percebemos é influenciado por como os outros nos respondem socialmente. A resposta negativa que vem dos outros pode afetar adversamente nossa auto-imagem. O elo entre atratividade física, a probabilidade de realização pessoal e aceitação social é, atualmente, bem esclarecida. A popularidade é mais atribuída para adultos com características de personalidade positiva, do que para adultos não atraentes. Os adultos atraentes tendem a apresentar mais habilidades sociais. Para esses autores, 0 elo entre beleza física e aceitação social sublinha as desvantagens potenciais para indivíduos afetados. Em relação à interação social, os autores afirmaram que uma aparência imperfeita leva os outros, de uma forma geral, a respostas sociais não favoráveis, conseqüência dos estigmas. Indivíduos com aparência 
imperfeita são julgados mais negativamente. E a não aceitação social pode reduzir os sentimentos de auto-valor, levando o indivíduo com desfiguração à possibilidade de problemas psicológicos.

Silva et al. (1999), ao considerarem as melhores condições de (re)habilitação da criança portadora de deficiência auditiva e a importância da família, propuseram um estudo para averiguar as características estruturais e funcionais da mesma e quais os recursos utilizados por ela para lidar com essa criança. Os autores elegeram uma amostra de 15 famílias com crianças portadoras de deficiência auditiva neurossensorial bilateral profunda, entre os dois e quatro anos de idade, as quais responderam uma entrevista semiestruturada e a um questionário. Os resultados, analisados a partir da Teoria Sistêmica, demonstraram que aparentemente as famílias possuem características de funcionalidade com nível satisfatório de comunicação; bom desempenho nos papéis parentais e condições satisfatórias para lidar com as situações de estresse. Apresentam os Mitos da União e do Trabalho e uma rede social amplamente fortalecida (que serviram de suporte e apoio), como importantes recursos para lidar com a deficiência auditiva. Para os autores, foi possível concluir que os recursos utilizados pela família, principalmente os mitos familiares, norteiam a sua estrutura e o seu funcionamento, favorecendo e garantindo o seu nível de funcionalidade.

Em 1999, 15 entrevistas semi-estruturadas foram conduzidas por Pain com 20 pais (cinco com ambos os pais e 10, somente com a mãe) de crianças deficientes que tinham comprometimento físico e dificuldades de aprendizagem, para explorar quais informações eles haviam recebido sobre a 
doença de suas crianças, de quem e se as mesmas foram úteis. As entrevistas foram filmadas e gravadas em fita que foram transcritas e tiveram seu conteúdo analisado. Comunicação pessoal foi o mais citado dos meios de informação. A maioria dos pais informou que, quase sempre, os profissionais foram suas fontes de informação, mas outros parentes e organizações de voluntários também foram mencionados. As informações encontradas facilitaram o processo de ajuste emocional dos pais às limitações das suas crianças e habilitaram os pais no acesso aos serviços e benefícios, além de melhorar o gerenciamento do comportamento de suas crianças.

Para Baumann e Braddick (1999), a transição para a paternidade é considerada um desafio emocional, físico e financeiro para muitos casais, sendo que, a existência de dificuldades para administrá-la, pode diminuir a competência dos pais e afetar o desenvolvimento da criança. Para estes autores, as crianças que têm pais que são parceiros ativos na paternidade, têm várias vantagens sobre as crianças que vivem a falta do envolvimento paternal. Esta participação paterna pode acontecer por meio do cuidado direto com a criança ou mesmo pelo apoio conjugal. Apesar da importância do envolvimento paternal, pouca informação está disponível sobre como os homens encontram soluções, tomam decisões e vêem o futuro enquanto pais, particularmente quando eles têm uma criança que é diferente. Assim, o propósito deste estudo descritivo exploratório foi descrever a paternidade experienciada por pais de crianças "diferentes", acrescentando ao atual entendimento de paternidade em geral, a paternidade de crianças diferentes. A perspectiva que sustentou este estudo e que serviu de base para a análise de seus resultados foi a teoria de 
Parse (tornar-se pessoa). Teoria esta que considera os indivíduos e a família como um processo mútuo que está sempre se constituindo. Participaram deste estudo, 11 pais biológicos de crianças com fissura lábiopalatina, de crianças com problemas cardíacos congênitos e de crianças com Síndrome de Down. Eram de classe média, trabalhadores, brancos, em seus primeiros casamentos e morando com os filhos, com idade entre 33 e 44 anos. Os resultados deste estudo indicaram que para os participantes, a paternidade é um desejo de tentar dominar a situação, misturado aos sentimentos perturbadores, enquanto encaram os próprios limites. Para alguns, a paternidade é algo inesperado, surpreendente, pois não se sabe nunca o que pode se esperar. Para eles a paternidade é um desafio, onde é necessário o uso da intuição para encontrar soluções para os problemas existentes. Quando os pais percebem que algo não vai bem com a sua criança, eles sentem necessidade de saber o que está envolvido, a gravidade e a demanda exigida. Para estes pais, tanto a preocupação como, também o foco de sua atenção, ficaram voltados para o presente e para a sobrevida de sua criança. Apesar dos participantes terem diversos sonhos e acreditarem na importância da flexibilidade, observaram que suas metas quase sempre eram inalteradas. Os pais lutavam para reconquistarem um senso de controle sobre seus mundos e sentimentos. Apesar de suas ambigüidades de sentimentos, sabiam que a paternidade pode proporcionar as melhores qualidades para a criança, se esta se desenvolver em um lugar onde possa se sentir segura, com harmonia e amor. Em conclusão, este estudo sugere que a preparação dos pais para lidar com uma criança diferente é fundamental para o seu desenvolvimento. 
Carvalho e Tavano (2000) fizeram uma avaliação dos pais diante do nascimento e tratamento dos filhos portadores de fissura labiopalatal, no Hospital de Reabilitação de Anomalias Craniofaciais da USP-Bauru, onde procuraram descrever e analisar as respostas dadas pelos pais de crianças portadoras de fissura labial e/ou palatal, diante do seu nascimento e início do tratamento no HRAC-USP, em Bauru, obtendo dados para caracterizar suas necessidades e subsidiar a confecção de vídeo educativo. Foram realizadas entrevistas semidirigidas com 40 pais de crianças portadoras da fissura labial e/ou palatal, durante o período pré-operatório. Os dados mais relevantes indicaram que $93 \%$ dos pais demonstraram reação de choque emocional, diante do nascimento do filho portador da fissura labiopalatina. No entanto, por ocasião do inicio do tratamento, $20 \%$ indicaram estarem se reorganizando. Abordando o tratamento, somente $30 \%$ compreenderam totalmente as orientações da equipe de profissionais e $47 \%$ afirmaram haver participado na tomada de decisões a respeito do tratamento. Com base nos resultados, concluí-se que os pais estão vivenciando o impacto do nascimento, apresentando desinformação e certa passividade diante do tratamento, demonstrando a necessidade de atuação psicológica sistemática e transmissão de informações de forma adequada e efetiva.

Quando uma criança tem uma inaptidão os pais experienciam estressores típicos associados com a paternidade e um grupo de estressores adicionais próprios com as condições de sua criança. Kerr e Mclntosh (2000) desenvolveram um estudo para explorar o impacto do apoio de pai-para-pai, especificando qualitativamente os seus benefícios para as famílias de crianças 
que nascem uma inaptidão congênita. Usaram o método fenomenológico para colher as experiências das famílias tendo como instrumentos uma entrevista retrospectiva e observação dos mesmos. Participaram deste estudo 63 pais de crianças nascidas com uma deficiência de membro superior congênita, de ambos os sexos e com idades que variavam de alguns meses a 16 anos. Os resultados deste estudo indicam que o tempo que se segue após o nascimento de um bebe com comprometimento é um período de perturbação emocional para a maioria dos pais. Sentimentos de isolamento e muita preocupação sobre o futuro eram comuns para todos. Embora os pais recebessem um certo apoio de contato com a família, amigos e profissionais de saúde, o nível de apoio recebido não era de acordo com o esperado. $O$ apoio recebido pelas enfermeiras era essencialmente prático e referia-se aos cuidados físicos com a criança como banho, alimentação etc, sendo pobres em apoio emocional. $\mathrm{O}$ apoio provido pelos médicos relacionava-se à busca de informações sobre as condições de saúde física da criança, a causa do comprometimento e as possibilidades de condições futuras de desenvolvimento. Este apoio foi percebido como inadequado pela falta de respostas concisas. Desta forma pais experienciavam com intensidade um sentimento de isolamento, pois acreditavam que a sua criança era a única no mundo. Este sentimento de isolamento se intensificava na medida que o contato com outras pessoas era sempre evitado, para que sua criança não fosse exposta. O contato com outros pais de crianças nascidas com uma deficiência de membro foi o apoio e a ajuda necessária identificada como adequada. A maioria dos pais sentia que pais que estavam em uma situação semelhante eram as únicas pessoas que 
verdadeiramente poderiam entendê-los. O conhecimento de pais de uma criança mais velha, que experienciou os mesmos passos que eles, ou com pais de uma criança de idade semelhante, estabelecia freqüentemente um laço imediato e intenso. O efeito da transformação promovida pelo contato com outros pais foi claramente evidenciado. Este apoio operou em vários níveis. Primeiro proveu um senso de "normalidade" no que previamente tinha sido considerada uma situação de "subnormal". Em segundo lugar, a descoberta que havia "outros pais que tinham compartilhado a mesma experiência" baniu qualquer sentimento de isolamento que os pais possam ter experimentado. Outro benefício era que, falando com outros pais, se encontrando ou ouvindo falar de outras crianças, os pais ajudados puderam visualizar, de um modo muito imediato, uma vida ativa e social normal para a sua criança. Também, o contato com outros pais proveu apoio emocional, dando para eles a oportunidade para falar sobre sentimentos de confusão, culpa, ansiedade, raiva e depressão que eles estavam experimentando. Finalmente, outros pais puderam prover conselhos práticos e apoiar, ajudando os pais novos a solucionar muitos problemas cotidianos. Concluindo, os resultados apresentados neste estudo apóiam a teoria que apoio de pai-para-pai pode mostrar-se uma influência poderosa de proteção ao estresse.

Em artigo publicado em 2001, Cavalcante procurou refletir sobre o impacto do nascimento social de uma criança "anormal" na família. O autor propôs uma grade conceitual, abstraída da antropologia e da filosofia da linguagem, que permita articular sujeito e contexto social. Analisou um rico material empírico, baseado em histórias de vida de famílias com filhos 
excepcionais, de uma pesquisa desenvolvida no município do Rio de Janeiro. Fez uma descrição densa das etapas iniciais, pelas quais a família passa, quando descobre a anormalidade mental de seu filho, na primeira infância. Este enfoque valorizou a capacidade das famílias de comunicarem sua experiência de enfrentamento da anormalidade, como aprendizado, luta e sabedoria de vida. As conclusões revelam que o momento do diagnóstico é delicadíssimo, pois transforma o ser da criança e inaugura um novo pai e uma nova mãe. As reações à dor serão inevitáveis. Um acolhimento e uma orientação clara são fundamentais. A rotina familiar se altera. Uma ética da responsabilidade e do sacrifício se impõe pelos cuidados ao filho. A família precisa desenvolver um novo estoque de conhecimento. O apoio familiar é crucial, para que a família tenha condições de fazer face ao desespero, à confusão, à desorientação. O combate mais difícil é contra a discriminação social porque traz, como conseqüência, uma dor que fere por dentro e por fora.

O objetivo do estudo de Broder (2001) foi oferecer uma visão geral, a partir da análise de pesquisas feitas com famílias de indivíduos com anomalias crânio-encefálicas e outras condições crônicas. Entre os aspectos analisados estão as avaliações psicológicas, a resiliência e estratégicas terapêuticas para melhorar o bem estar psicológico. O autor concluiu que a leitura das condições crônicas e dos achados nos estudos com pessoas com anomalias crânio-facial e suas famílias demonstraram uma escala de efetivos padrões adaptativos e estratégias para melhorar as questões que tenham impacto sobre a qualidade de vida. 
Lam e Mackenzie (2002) buscaram por meio deste estudo, obter uma compreensão detalhada dos estressores específicos, dos recursos e das estratégias de enfrentamento utilizadas pelas mães de crianças com Síndrome de Down. Os dados foram obtidos por meio de entrevistas semiestruturadas realizadas com 18 mães de crianças com síndrome de Down, na faixa etária de 2 a 6 anos. A escolha desta população se deu pelo fato destas crianças terem que ficar mais tempo em casa e os pais terem que assumir mais cuidados e responsabilidades, cabendo também, a estes pais, integrarem a criança na família e principalmente na sociedade chinesa, onde as pessoas mentalmente prejudicadas não são bem aceitas. Os autores deste estudo consideraram a condição encontrada em ampla literatura de que os pais de crianças com inaptidões experimentam um maior nível de tensão do que os pais de crianças sem inaptidões. Isso acontece porque eles têm que enfrentar a perda da criança normal "esperada" e aceitar a realidade de ter uma "criança defeituosa". A incerteza, a longo prazo, da viabilidade da criança, saúde futura, crescimento e a habilidade da família para satisfazer as necessidades da criança são fatores que acrescentam mais tensão psicológica aos pais. Psicologicamente os pais têm que gastar a maior parte de seu tempo, energia, e paciência no cuidado de sua criança. Eles têm que administrar a saúde da criança, os problemas emocionais e de comportamento e/ou a treinar habilidades diárias. Sete temas principais foram identificados representando os maiores estressores: nascimento inesperado de uma criança anormal, aceitação da criança, necessidades especiais da criança, preocupação sobre o futuro, pouca informação, efeitos no relacionamento do casal e restrições 
sociais. Em relação a aceitação da criança, a maioria dos pais relatou ter vivido um choque opressivo, descrença e negação da sua criança, quando informados sobre o diagnóstico da síndrome de Down, no entanto, a partir das primeiras semanas ou dos primeiros meses, esta aceitação teve início. Quanto às necessidades especiais da criança, estas trouxeram demandas não antes existentes para as mães, que tiveram que levar as suas crianças cedo para a educação e programas de treinamento. A rotina diária de alimentar, vestir, carregar, higienizar e transportar uma criança com um impedimento provocam muito desgaste. Crianças com Síndrome de Down geralmente têm problemas de saúde e muitas requerem hospitalização freqüente. As mães considerarem insuficiente o conhecimento sobre diagnóstico da Síndrome de Down e sobre os cuidados de uma criança com esta síndrome. Em relação aos efeitos no relacionamento do casal, duas mães informaram que as suas relações matrimoniais melhoraram depois do nascimento da criança porque seus maridos compartilharam com a mesma meta em relação à criança. Porém, a maioria das mães sentia que havia efeitos adversos no relacionamento matrimonial delas, porque seus cônjuges mostraram indiferença à criança e se recusaram a compartilhar as responsabilidades de cuidado. As restrições sociais ocorreram em função das limitações impostas às mães depois do nascimento da criança com Síndrome de Down. Além do cuidado cotidiano, tiveram que acompanhar as crianças a programas de treinamento, impedindoas de participar de outras atividades sociais. Outra razão da restrição social foi o comportamento difícil das crianças sindrômicas. A maioria dessas mães teve que deixar de trabalhar, tornando-se financeiramente dependente. Mais de um 
terço não relataram para seus amigos sobre a condição da sua criança, conseqüentemente isso fez com que evitassem o contato social. Confirmando estudos que indicam sentimentos de tristeza e de depressão severa, experimentados em graus variados, pela maioria dos pais de crianças com inaptidões ao nascimento, os resultados deste estudo reforçam os achados na literatura e indicam que, a presença de uma criança com Síndrome de Down é uma fonte contínua e significante de tensão para as mães. Afirmam também que os tipos de mudança de agentes estressores, com o passar do tempo, se alteram. As mudanças eram classificadas em três fases de acordo com a idade da criança: do nascimento aos seis meses, dos seis meses aos dois anos e dos dois aos seis anos. O período mais difícil era o do nascimento até aos dois anos. A Chinese Parental Coping Scala usada neste estudo, identificou quatro estilos principais de enfrentamento: autoconfiança, apelação a um poder de sobrenatural, busca de apoio social e evitação. Mães da faixa etária de zero a seis meses relataram estratégias de enfrentamento focalizadas na emoção e na negação. Mães da fase seguinte relataram que as estratégias geralmente usadas eram a autoconfiança, busca de apoio social e evitação. Isso indicava que o enfrentamento focado no problema havia sido somado com o enfrentamento de foco emocional da primeira fase. Mães da terceira fase, de crianças de dois a seis anos, apresentaram emoção-focalizada e problemafocalizado, que foram estratégias empregadas nesta fase, resultando em autoconfiança e busca de apoio social. O trabalho realizado demonstrou que os profissionais têm um papel muito importante para atuar neste contexto cultural, pois manter as aparências e a harmonia são características de cultura 
chinesa, influenciando o comportamento de busca de ajuda neste grupo de mulheres. Médicos, enfermeiros e assistentes sociais devem proporcionar as famílias todo o conhecimento necessário sobre as condições realísticas da síndrome, da mesma forma que devem estimular as mães a expressarem seus sentimentos, a buscarem apoio e ajuda, bem como esclarecer e desmistificar mitos e preconceitos sociais, para melhor favorecer a aceitação da criança com síndrome de Down.

Para Taanila et al. (2002), o nascimento de uma criança inválida é um evento que afeta todos os membros familiares e suas relações internas e externas, exigindo um reajustamento do funcionamento familiar. Para este enfrentamento a família usa os seus recursos existentes e de estratégias. Estas estratégias de enfrentamento estão definidas como processos ativos e comportamentos que a família tenta empregar para controlar, administrar de fato, adaptar ou lidar com uma situação de estresse. Assim sendo, estes autores desenvolveram um estudo com o objetivo de descobrir como as famílias com crianças fisicamente ou intelectualmente inválidas têm enfrentado estas condições e que tipo de estratégias de enfrentamento os pais utilizaram. Participaram deste estudo oito pais de crianças (oito a 10 anos de idade) com deficiência física e/ou intelectual. Os resultados deste estudo indicaram que quatro das oito famílias pareciam ter achado modos de enfrentamento bem sucedidos (grupo de elevado-enfrentamento), enquanto que, as outras quatro famílias tinham tido muitos problemas (grupo baixo-enfrentamento). As estratégias de enfrentamento mais freqüentemente usadas pelos pais foram: informação e aceitação, boa cooperação familiar e apoio social. A expressão 
de sentimentos e afetos, assim como experiências de lazer, foram consideradas úteis no processo de enfrentamento de situações estressantes causadas pela criança. As famílias em ambos os grupos usaram estratégias semelhantes de enfrentamento, mas o grupo de elevado enfrentamento teve um repertório maior na utilização das mesmas. Contrariamente ao grupo de elevado enfrentamento, os tópicos de conversação nas famílias de baixoenfrentamento eram quase sempre os problemas experimentados pela família em lugar dos esforços que fizeram para resolvê-los. Em todos os tópicos acima mencionados as famílias de elevado enfrentamento tiveram maiores vivências. Concluindo, os autores afirmam que, reconhecendo as estratégias de enfrentamento usadas pela família e os indicadores de risco de um enfretamento pobre, os profissionais são muito importantes na colaboração do lidar com a perspectiva de toda a família.

Trute e HieberT-Murphy (2002) realizaram um estudo com o objetivo de desenvolver a Escala do Impacto sobre a Família do Deficiente Infantil (FICD) para avaliar o impacto da presença de uma criança com deficiência mental na família. Os autores utilizaram uma amostra aleatória de 87 famílias, que foram avaliadas enquanto as suas crianças com deficiência de desenvolvimento estavam em idade pré-escolar. Após sete anos, 64 destas famílias foram entrevistadas outra vez, quando as crianças estavam na préadolescência. Ofereceram aos pais uma série de medidas padronizadas sobre a visão da criança, dos pais e do funcionamento familiar. A Escala aplicada neste estudo demonstrou em seus resultados, uma adequada consistência interna, com algumas evidências de previsões válidas. A contagem total desta 
escala, baseada na diferença entre as subescalas positivas e as negativas, encontrou um sinal significante de estresse futuro para as mães e pais, ainda que haja controle de outras variáveis importantes, tais como o ajuste do casal e o nível de deficiência da criança.

Em trabalho publicado em 2002, Salles et al.. verificaram a importância da família na reabilitação e formação profissional do paciente portador de deficiência auditiva, como também no processo de inclusão social dos pacientes deficientes auditivos. Os resultados da pesquisa evidenciaram as contribuições que a família proporciona no processo reabilitador dos portadores de deficiência auditiva, matriculados no Núcleo Integrado de Reabilitação e Habilitação (NIRH/HRAC/USP/Bauru), no ano de 1998.

Em 2002, Holmbeck et al.. realizaram um estudo com o objetivo de examinar o funcionamento sistêmico da família em diversos domínios (conflitos, coesão e estresse). Foram sujeitos desse estudo 68 famílias de préadolescentes com espinha bífida e 68 famílias com pré adolescentes saudáveis, todos na faixa etária de oito a nove anos. Para a coleta de dados foi utilizado um questionário respondido tanto pelos pais como pela criança e a observação do comportamento familiar. Os resultados deste estudo revelaram que, comparado ao grupo de crianças saudáveis, o grupo de famílias com crianças com espinha bífida foi menos coeso e as crianças desta amostra foram mais passivas durante as tarefas de interação familiar. Análises adicionais sugeriram ainda que, algumas destas associações significantes entre o status do grupo e funcionamento familiar foram medidas por indicações de QI verbal, indicando que uma parcela significante do resultado do grupo foi 
devido a variações funcionais cognitivas das crianças. Famílias com baixo status socioeconômico demonstraram níveis mais altos de conflito entre a mãe e a criança e menor coesão familiar nos eventos de vida. Nas famílias com crianças com espinha bífida, os pesquisadores observaram uma alteração da resiliência no funcionamento sistêmico familiar.

As funções orofaciais incluem competências ou habilidades, como comer, respirar e comunicar pela fala ou mímica, além da saúde bucal. Perturbações nestas funções são comuns em crianças com doenças raras. Trulsson e Klingberg (2003), com o objetivo de descrever as experiências dos pais de crianças com disfunção orofacial e as necessidades de crianças com doenças raras, realizaram minuciosas entrevistas com 14 pais, nos locais de tratamento. Duas categorias emergiram do núcleo dos dados na análise: a "família vulnerável" e a que "recebeu apoio de outros". Os dados indicaram a importância do equilíbrio entre estas duas categorias: a tensão causada na vida de uma família com uma criança com incapacidades ou doença severa, e a disponibilidade de apoio recebido da parte do pessoal envolvido no tratamento e outros apoios significativos. Este equilíbrio foi indispensável no desenvolvimento da auto-confiança dos pais e na reconciliação com suas situações pessoais.

Conforme estudos que já foram citados anteriormente, sabe-se que a presença de uma criança com inaptidões provoca uma variedade de demandas de tensão na família. Porém, é pouco conhecida a influência da religião no lidar com a mesma, entre as famílias de grupos religiosos. Por esta razão, Marshall et al. (2003) em estudo descritivo, explorou temas de convicção espiritual e 
religiosas em que se apóiam as famílias da Igreja de Jesus Cristo dos Últimos Dias (LDS, ou mórmon) e como eles se adaptam à circunstância de conviverem com uma criança com inaptidões. Estes investigadores examinaram forças, saúde e resiliência entre tais famílias, considerando a religião como possível de ser uma variável importante nesta troca conceitual. O objetivo da pesquisa era identificar quais os temas da prática religiosa e de convicção espiritual que são informados às famílias LDS que influenciam a adaptação e a convivência com uma criança com inaptidões. Foram entrevistados 32 pais (16 casais), com idade entre 28 a 51 anos, de crianças matriculadas em escolas de educação especial com comprometimentos variados: físicos, mental, desordens e/ou atraso de desenvolvimento, síndrome de Down, paralisia cerebral, desordens de comunicação e outras, com idades que variavam a de um ano a 18 anos. Os resultados obtidos por este estudo indicam que as famílias relataram uma condição de adaptação geralmente positiva na crise inicial de convivência com a sua criança. Três temas emergiram como contribuintes dessa vivência e com a expansão e construção da fé pessoal: 1- Convicções compartilhadas com as doutrinas da igreja; 2Apoio social da comunidade da igreja e, 3- A união da família na participação de práticas religiosas. $\mathrm{O}$ poder de oração especificamente foi citado como sendo extremamente reconfortante. Especificamente, a religião foi mencionada como uma estratégia de enfrentamento, pois por causa dela a criança era vista como uma benção e os pais como sendo santificados por ela. Dentro da convicção religiosa, a criança tinha um propósito metafísico e a família tinha sido determinada por uma confiança sagrada e divina. A crença de que havia 
uma relação entre uma vida antes e depois da mortalidade deles com a criança de necessidades especiais oferecia conforto e responsabilidade, além de um senso de entendimento que transcendia a realidade diária deles, eliminando o sentimento de injustiça.

Sank et al. (2003), com o objetivo de identificar os fatores que podem predizer o apoio social percebido em mães de crianças com fissura labiopalatina, entrevistou 145 deles (90 pais e 55 mães) utilizando uma Avaliação de Apoio Interpessoal e o Inventário Beck de Depressão. Os resultados deste estudo possibilitaram a conclusão que as mães de crianças com fissuras visíveis, relataram mais o apoio social recebido do que as mães de crianças com fissura não visível. Mães de meninas relataram mais apoio social do que as mães de meninos. Mães com escolaridade mais alta relataram significativamente mais apoio social do que mães de que tinham menos escolaridade. Mães com mais filhos relataram níveis mais baixos de apoio social. A depressão materna era altamente correlacionada com apoio social percebido. Conclusões: a visibilidade da fissura labiopalatina, o tamanho familiar, o sexo de criança e o nível de educação materno foram fatores importantes para predizer o apoio social recebido por mães de crianças com fissura labiopalatina. A idade de criança e história familiar não foram predictores significantes.

O estudo de Gray (2003) analisa a possível relação entre gênero e enfrentamento, tendo como participantes vinte e um pais e trinta e duas mães de crianças autistas ou com síndrome de Asperger. Gênero (masculino e feminino) é um conceito que tem sido freqüentemente discutido na literatura 
sobre estresse, enfrentamento e doença. A hipótese é de que as mulheres são muito mais vulneráveis do que os homens em situações estressantes e que usam estratégias de enfrentamento diferentes. Além disso, estas diferenças em enfrentamento baseadas no gênero podem, particularmente, explicar o impacto diferente de eventos estressantes em homens e mulheres. Neste estudo os pais responderam a um questionário semi-estruturado incluindo as seguintes categorias: o início dos sintomas, referência à experiência e diagnóstico, a natureza dos sintomas presentes na criança e os efeitos do autismo na família. Incluíram, também, questões sobre o papel dos membros da família, a natureza dos problemas da criança autista presentes na família, as estratégias usadas pelos pais para enfrentamento e o efeito das situações na vida destes pais. Os resultados do estudo indicaram que, em relação ao papel dos pais, as diferenças maiores entre pai e mãe são as diferenças pessoais quando no impacto com a criança autista. A maioria dos pais relata não ter grandes dificuldades com a criança autista na família, eles usualmente reclamam que a condição das crianças não tem efeitos significativos em sua personalidade. Quanto às mães, a maioria reclama que as crianças autistas afetam severamente seu bem estar emocional. Muitas mães têm experimentado estresse necessitando de psicoterapia e medicação. Em outros casos, mães têm experimentado doenças físicas ao lidar com a criança autista. Desta forma, o autor conclui que entre os pais deste estudo, os papéis de mãe e pai são consideravelmente diferentes. As mães vivem o impacto negativo da inabilidade cotidiana de seus filhos. 
Maronês et al. (2003) desenvolveram um trabalho cujo objetivo foi avaliar o impacto sofrido pelos pais ao receberem o diagnóstico de deficiência auditiva do filho e verificar como se processa o enfrentamento ou "conduta" dos mesmos diante do problema. Participaram deste estudo 30 mães de crianças com deficiência auditiva, na faixa etária de 20 a 44 anos. Os dados analisados foram obtidos por meio de entrevista semi-estruturada, durante o primeiro atendimento no setor de Psicologia, do Centro de Pesquisas Audiológicas (CPA) do Hospital de Reabilitação de Anomalias Craniofaciais da USP, BauruSP. Os resultados deste estudo constataram o impacto da deficiência auditiva nos pais, que experienciaram dor e sofrimento em função desta. Concomitantemente, procuram atendimento em instituições especializadas favorecendo uma intervenção precoce.

O estresse desencadeado pelo diagnóstico de anormalidade congênita infantil foi o objetivo do estudo conduzido por Uzark e Jones (2003), relatado por pais de crianças com doenças cardíacas. A amostra deste estudo foi de 80 pais, sendo 70 mães e 10 pais que acompanhavam seus filhos, na faixa etária de dois a 12 anos, como pacientes externos em clinica de cardiologia pediátrica. Quarenta e uma crianças tinham distúrbios cardíacos simples, que não requeriam intervenções terapêuticas, enquanto que 39 crianças apresentavam doenças caracterizadas como complexas que exigiram correções cirúrgicas. Estes pais responderam durante a visita à clínica ao Parenting Stress Index (PSI). Este instrumento compreende três sub-escalas: angústia dos pais, interação disfuncional entre pais e filhos e dificuldades da própria criança. Este estudo revelou que pais de crianças com doenças 
cardíacas apresentam um resultado total de estresse muito maior e mais significativo quando comparados com uma amostra normal. Examinando os resultados das sub-escalas, os pais de crianças com doenças cardíacas têm elevado nível de estresse em relação a sub-escala que se refere às dificuldades da criança, quando comparados a uma amostra de normalidade. Em relação à angústia dos pais, esta não foi relatada como sendo de diferença significativa para os pais de crianças com doenças mais complexas e/ou mais simples, portanto a tensão dos pais se apresentou sem conexão à severidade da doença de coração da criança. No entanto, pais de crianças mais velhas, relataram maior estresse. É fácil de entender isso: como a criança está avançando na idade, pode ficar mais difícil para pais fixar limites e manter o controle. Ansiedades dos pais vividas no passado e superproteção podem conduzir a problemas futuros, particularmente durante adolescência quando as crianças buscam a independência. Concluindo, embora usualmente é reconhecido que o nascimento de uma criança com doença de coração aumenta tensão para as famílias, este estudo sugere que estes pais enfrentam tensões importantes na infância, aumentando com a idade do filho.

Rodrigues et al. (2003) realizaram um projeto com 10 pais e quatorze mães de bebes com fissuras labiopalatinas, durante a rotina de primeira consulta, no Hospital de Reabilitação de Anomalias Craniofaciais (HRAC/USPBauru), com o objetivo de descrever e analisar as reações destes pais, por ocasião do nascimento de seu filho e no momento da entrevista. Os resultados desta pesquisa indicaram que a maioria das mães entrevistadas não sabia da condição da criança antes do nascimento. O não conhecimento desta condição 
em seus filhos provocou, no momento do nascimento, sentimentos negativos como: nervosismo, choque, susto, surpresa e medo. Algumas destas mães relataram que choraram e, para apenas uma, houve a recusa de ver a criança. Outras não relataram sentimentos negativos ou positivos, referindo-se apenas à dificuldade em lidar com a família. Em relação às condições atuais sobre o bebê, as pesquisadoras observaram uma crescente organização das mães no sentido de resolver o problema, buscando diagnóstico e encaminhamentos futuros que possibilitem a reabilitação, uma condição melhor de encararem a situação, sentimentos mais positivos com relação à condição de seus filhos e boas expectativas quanto aos resultados das cirurgias previstas. Algumas mães relataram a importância da ajuda divina neste período. Dos pais entrevistados, a maioria, teve reações de sentimentos negativos como susto, angústia e inconformidade com a situação. Quanto às reações atuais destes pais, também a maioria, buscou tratamento para a criança contando com a possibilidade de reverter definitivamente a condição da criança. As autoras concluem afirmando a necessidade de apoio para estes pais, a fim de conseguirem superar as angústias iniciais e auxiliarem no desenvolvimento de seus filhos.

O objetivo da pesquisa desenvolvida por Fávero (2005) foi investigar a sobrecarga emocional (estresse e depressão) em mães de crianças com autismo, verificar a relação dessa sobrecarga com a avaliação da qualidade de vida e conhecer as principais dificuldades decorrentes da demanda de cuidados com o filho e os modos de enfrentamento. As participantes da pesquisa foram 20 mães de crianças com autismo, vinculadas a duas 
instituições de atendimento. Com cada participante foi realizada uma entrevista com roteiro semi-estruturado e aplicação assistida dos instrumentos de avaliações padronizados: Inventário de Sintomas de Stress para Adultos de Lipp (ISSL), Escala de Modos de Enfrentamento de Problemas (EMEP), Inventário Beck de Depressão e Escala de Qualidade de Vida (WHOQOL-Bref), complementados por um questionário de identificação do perfil sociodemográfico e cultural. As entrevistas foram realizadas nas dependências da instituição e/ou na casa da participante. As entrevistas foram gravadas em áudio, posteriormente transcritas e submetidas à análise de conteúdo temática. Para a verificação estatística das relações existentes entre as variáveis do estudo, foi utilizada correlação não-paramétrica. Os resultados obtidos nas avaliações indicam que $65 \%$ das mães apresentaram estresse. Com relação aos sintomas depressivos, uma participante apresentou disforia e duas mães apresentaram depressão. A análise do enfrentamento permitiu verificar que $45 \%$ das participantes utilizaram estratégias predominantemente focalizadas em práticas de cultos religiosos e pensamento fantasioso e $35 \%$ das mães utilizaram estratégias focalizadas no problema. O aspecto melhor pontuado referente à qualidade de vida foi o domínio físico, ao passo que o domínio meio ambiente foi o menos pontuado. Considerando as inúmeras possibilidades de reflexão, a análise da entrevista semi-estruturada permitiu a discussão de alguns temas: a trajetória da família na busca de compreender o problema da criança, constituindo um movimento de peregrinação por hospitais e profissionais de saúde; o luto enfrentado pela família e as dificuldades de lidar com a condição da criança; as mudanças na dinâmica familiar e a sobrecarga 
emocional materna que, culminou num processo de racionalização do sofrimento; o desamparo sentido pelos pais no que se refere às perspectivas futuras de cuidado com o filho.

Embora este levantamento bibliográfico reflita grande diversidade quanto à definição e mensuração do enfrentamento, os resultados têm demonstrado consistentemente que situações problemáticas podem não apenas resultar em grande estresse emocional, como também, em longo prazo, apresentar efeitos cumulativos, tanto de natureza física como psicológica. Além disso, os estudos também têm demonstrado que situações problemáticas e estressantes podem favorecer a adoção de estratégias de enfrentamento, que minimizem a experiência desgastante e facilitem a manutenção de níveis razoáveis de bem-estar psicológico por parte da pessoa diante do contexto de estresse. 


\section{PROPOSIÇÃO.}

A presença da fissura labiopalatina, em suas diferentes expressões, por envolver um processo de reabilitação com extensão temporal, pode influenciar a dinâmica da família e provocar diferentes atitudes de enfrentamento. Desta forma, este estudo tem como objetivo geral descrever e analisar o processo de enfrentamento vivido por pais de pessoas com fissura labiopalatina, nos seguintes períodos do desenvolvimento humano: por ocasião do nascimento, no início da educação formal e na adolescência. Quanto aos objetivos específicos, este estudo se propõe a: 1) Descrever as reações dos pais em cada fase do desenvolvimento e, 2) comparar as reações destes nas diferentes fases do desenvolvimento.

Tal propósito visa colaborar com o acúmulo de conhecimentos sobre a fissura labiopalatina e suas diversas implicações, bem como identificar o que acontece com essa população, para melhor e eficaz intervenção. 


\section{MATERIAL E MÉTODOS.}

\subsection{Casuística.}

Participaram deste estudo 150 pais de pacientes com fissura transforame incisivo, unilateral ou bilateral, regularmente matriculados no Hospital de Reabilitação de Anomalias Craniofaciais-USP (HRAC).

Os pais participantes foram selecionados de acordo com a faixa etária de seus filhos e identificados na relação dos agendamentos de rotina do HRAC. Os mesmos foram convidados a participar deste estudo e esclarecidos a respeito de sua liberdade de participação.

Como critério de elegibilidade dos pais participantes, além de se considerar a idade de seus filhos, acima citada, considerou-se também a condição destes não apresentarem outros comprometimentos, tais como: síndromes, deficiência mental, e/ou malformações físico/sensoriais, assim como quaisquer distúrbios de outra natureza. As variáveis: idade, escolaridade, região de procedência e nível socioeconômico dos participantes não foram consideradas como critério de seleção dos pais. Dessa forma, foram chamados para a entrevista pais de pacientes vindos para a rotina dos procedimentos normais à reabilitação, que se encaixavam nas condições acima descritas.

Os pais participantes foram divididos em três grupos, assim constituídos: GRUPO 1 (G1): 50 pais de pacientes com fissura transforame incisivo não operada, com menos de dois anos de idade; GRUPO 2 (G2): 50 pais de pacientes com fissura transforame incisivo operada, na faixa etária de seis a 
oito anos de idade; GRUPO 3 (G3): 50 pais de pacientes com fissura transforame incisivo operada, na faixa etária de 12 a 15 anos de idade.

A escolha destas faixas etárias foi estabelecida pelo fato delas corresponderem aos períodos mais significativos do desenvolvimento humano: ocasião do nascimento, início da educação formal e adolescência. Isso possibilitou avaliar o que os pais pensavam e como se sentiam em relação ao enfrentamento das dificuldades inerentes a estes momentos.

Os pais participantes pertenciam a ambos os gêneros, sem que se tivesse a preocupação de uma condição de igualdade quantitativa entre os mesmos.

Inicialmente, a proposta deste trabalho contava com a participação de um quarto grupo, constituído por pais de pacientes com fissura transforame incisivo que estivessem na faixa etária dos 18 aos 25 anos, momento este próprio para a profissionalização. No entanto, lidou-se com a dificuldade de contatar os pais deste grupo específico, pois a própria filosofia do HRAC estimula os pacientes nesta faixa etária, a uma maior autonomia, o que faz com que os mesmos compareçam para a rotina de seus atendimentos desacompanhados. À priori, pensou-se, também, em se trabalhar com pais de pacientes com fissura préforame incisivo e pós-forame incisivo. No entanto, optou-se pelo tipo de fissura transforame incisivo, por esta trazer comprometido não somente o aspecto estético como também o funcional. Sabe-se que a fissura pré-forame incisivo, apesar do impacto que provoca no momento do nascimento, não apresenta maiores comprometimentos funcionais, se restringindo, principalmente ao aspecto estético tendo um processo de reabilitação que ocorre nos primeiros 
anos de vida; a fissura pós-forame incisivo, cujo comprometimento refere-se a aspectos funcionais, apesar de sua reabilitação ocorrer num tempo maior durante o seu desenvolvimento, a mesma não provoca um impacto tão significativo no momento do nascimento, por passar mais desapercebida. Todas estas considerações contribuíram a escolha do tipo de fissura transforame incisivo como critério de escolha de estudo.

\subsection{Material.}

Como instrumento de coleta de dados foi utilizado um protocolo de entrevista, elaborado por esta autora, para ser especificamente utilizado neste estudo, contendo perguntas abertas e fechadas (Anexo 1).

Este instrumento foi estruturado em duas partes. A primeira parte (parte A) constou de dados que se referiam à identificação do pai participante (gênero, idade, estado civil, escolaridade e nível socioeconômico e região de procedência) como também de dados de identificação sobre seu filho(a) paciente (gênero, idade e escolaridade).

A segunda parte do protocolo (parte B) teve como foco de investigação o processo de enfrentamento vivido por estes pais, em função da fissura labiopalatina de seus filhos, nos períodos críticos do desenvolvimento. 0 primeiro item da parte B do protocolo de entrevista teve como objetivo investigar a condição de exposição do filho(a) com fissura labiopalatina em situações condizentes com cada faixa etária. Já o segundo item desta 
segunda parte avaliou o ponto de vista dos pais sobre o significado desta fissura para seu filho.

Com possibilidade de múltipla escolha, o item número três investigou os sentimentos experenciados pelos pais na fase de desenvolvimento em questão de seu filho(a); do mesmo modo que o item número quatro buscou identificar as atitudes de enfrentamento que estes pais apresentaram diante dos sentimentos e das condições por eles experienciadas.

Ainda usando da possibilidade da múltipla escolha, o quinto item teve como objetivo avaliar a rede de apoio que ajudou estes pais a enfrentarem as dificuldades provocadas pelas fissuras labiopalatinas de seus filhos. No sexto item, se buscou identificar os fatores que determinaram as atitudes de enfrentamento. Finalmente, o sétimo, o oitavo e o nono item da parte $B$ objetivaram identificar a influência (positiva ou negativa) da existência da fissura labiopalatina no relacionamento familiar, conjugal e com os outros filhos.

\subsection{Local.}

A coleta de dados foi realizada nas dependências do HRAC. Elas aconteceram em salas de espera e/ou ao ar livre, nas imediações do quiosque (área interna do HRAC), próximo aos locais dos atendimentos agendados aos pacientes. No entanto, foram garantidas todas as condições de privacidade necessárias.

\subsection{Procedimento.}


Previamente ao início deste trabalho, foi elaborado o projeto de pesquisa e submetido à avaliação do Comitê de Ética em Pesquisa do Hospital de Reabilitação de Anomalias Craniofaciais - USP, tendo sido aprovado (Ofício $\mathrm{n}^{\circ}$ 289/2003-UEP-CEP), (Anexo 2).

Antes de se iniciar a coleta de dados por meio do protocolo de entrevista, cada participante foi esclarecido a respeito de sua liberdade de participação na referida pesquisa. Foram-Ihe garantidos os termos de sigilo e privacidade das informações por ele oferecidas, assim como da sua identidade, no caso da divulgação dos resultados desta pesquisa. O participante, consciente de que sua recusa em participar nada implicaria sobre a continuidade do tratamento de seu filho(a), teve seu consentimento registrado em um termo de concordância (Anexo 3).

A aplicação desse instrumento foi realizada previamente com cinco sujeitos para a verificação da adequação dos itens a serem investigados. Verificadas as necessidades, mudanças condizentes para a melhoria do instrumento foram realizadas.

Teve-se, desde o primeiro momento, o intuito de se estabelecer com o paciente entrevistado uma condição de rapport (bem-estar), para colocá-lo mais à vontade com a pessoa do entrevistador e diante do instrumento em si. Essa conduta permitiu maior aproximação da pesquisadora com os sujeitos, propiciando o relacionamento interpessoal e facilitando o esclarecimento de dúvidas. 
As entrevistas foram realizadas individualmente, quando somente um dos pais presentes ou quando possível, com a presença de ambos os pais. A duração média de cada uma foi de, aproximadamente, 30 minutos.

Os dados foram coletados tanto pela própria pesquisadora como pela colaboração de dois assistentes previamente treinados.

\subsection{Análise dos dados.}

Os dados coletados foram dispostos em tabelas de dupla entrada, onde nas linhas configuravam-se as distribuições multinomiais e, nas colunas suas classes, cujos resultados das freqüências de ocorrência foram analisados por meio do teste de Goodman para contrastes entre e dentro de proporções multinomiais (Goodman 1964,1965). Para a indicação dos resultados do teste estatístico, foram colocadas letras minúsculas ao lado das respectivas proporções para indicar as diferenças significantes entre proporções multinomiais (linhas: análise intergrupos). No que diz respeito a comparações dentro das multinomiais (colunas: análise intragrupos), foram colocadas letras maiúsculas ao lado das proporções. A interpretação das letras é feita da seguinte forma: $1^{\circ}$ ) na comparação das linhas, fixam-se as colunas e, proporções seguidas de pelo menos uma mesma letra minúscula não diferem entre si estatisticamente $\left.(p>0,05) ; 2^{\circ}\right)$ na comparação das colunas, fixam-se as linhas e, proporções seguidas de pelo menos uma mesma letra maiúscula não diferem entre si estatisticamente $(p>0,05)$. $O$ valor de cada letra obedece ao aparecimento delas no alfabeto (A menor que $B$ menor que $C . .$.$) , sendo que a$ 
cada análise vale a letra maior. Este procedimento foi aplicado nas seguintes Tabelas 1, 2, 3, 4, 5, 6, 7, 8, 17, 18, 19, 20 e 21.

Para a análise estatística dos dados revelados nas Tabelas $9,10,11,12,13$, 14, 15 e 16 foi utilizada a técnica da análise de variância não paramétrica (Kruskal-Wallis), complementada com o respectivo teste de comparações múltiplas (Norman e Streiner 1994).

As tabelas que receberam tratamento estatístico foram elaboradas contendo os grupos estudados: G1, G2 e G3. Essas tabelas foram discutidas segundo interpretação do resultado relativo a comparações dos grupos estudados.

O aspecto referente ao nível sócioeconômico foi analisado de acordo com as categorias utilizadas pela ficha Serviço Social do HRAC-USP, considerada como um dos indicadores da classificação socioeconômica (Anexo 4). As sete categorias existentes nesta ficha, depois de tabulados os dados, foram agrupadas em apenas duas categorias (Baixa e Média), desta forma, os participantes indicados como pertencentes aos níveis $\mathrm{F}-\mathrm{BI}$ e E-BS foram incluídos na classe econômica baixa e os participantes pertencentes aos níveis D-MI e C-M foram incluídos na classe econômica média. Não houve nenhum participante que se incluísse nas categorias N/C, B-MS e A-AL, o que permitiu eliminá-las na demonstração da Tabela 6.

Os 30 sentimentos oferecidos para escolha foram classificados individualmente na comparação entre os grupos e em duas categorias: sentimentos positivos e sentimentos negativos. Considerou-se como sentimentos positivos e/ou negativos aqueles que usualmente e de acordo 
com o senso comum, assim são determinados como tais. Esses sentimentos oferecidos para opção pessoal enquadraram-se, depois de totalizados, dentro das seguintes categorias: positivos e negativos. Dessa forma, foi considerado como positivo o sujeito que se auto-atribuiu sentimentos positivos em número superior aos sentimentos negativos e vice-versa. Para a classificação dos sentimentos como positivo e/ou negativo, observou-se a concordância com o senso comum. Dentro de uma cultura de valores humanistas como a existente, são considerados sentimentos positivos aqueles que cultivados por beneficiarem o convívio afetivo-social e, classificados como negativos, os que de alguma maneira podem prejudicar as relações interpessoais. Segundo Romero (1998), os sentimentos positivos estão vinculados ao ego-sintônico e orientados pela simpatia e pela valorização, enquanto os sentimentos negativos originam-se do ego-distônico e orientam-se pela antipatia e pelo desvalor.

O mesmo procedimento foi seguido na tabulação dos dados referentes às atitudes de enfrentamento frente à condição de vivência de seus filhos utilizadas pelos participantes. Para a análise dos resultados, as citações foram consideradas individualmente na comparação entre grupos e, também, categorizadas em dois grupos: atitudes de enfrentamento positivas e negativas. Para a análise da possível rede de apoio utilizada por estes pais, seguiu-se o mesmo procedimento metodológico utilizado em outras categorias já mencionadas. As oito opções foram incluídas dentro das categorias: busca de apoio do tipo individual e busca de apoio no coletivo. 
Quanto aos fatores que determinaram as atitudes de enfrentamento, as sete opções foram incluídas naquilo que se pode estabelecer como sendo fatores externos e fatores internos.

Considerando a influência da fissura labiopalatina no relacionamento familiar, conjugal e nos outros filhos, a especificação de ser esta influência positiva e/ou negativa foi respondida apenas pela população que reconheceu a existência desta influência, que se encontrava no estado civil de casado, na ocasião da coleta de dados e por aqueles que não tinham apenas um único filho. Desta forma, obteve-se nestas questões uma diferenciação no total de pais participantes em cada grupo.

Todas as conclusões no presente trabalho foram discutidas no nível de 5\% de significância. 


\section{RESULTADOS.}

A partir das tabulações obtidas nas 150 entrevistas realizadas, pôde-se apresentar os resultados, analisando-se os aspectos referentes à identificação dos participantes e da influência da fissura labiopalatina nas vivências próprias do sujeito fissurado e de sua família.

5.1 Identificação geral dos pais entrevistados.

Para a identificação dos participantes, consideraram-se os dados referentes à faixa etária, gênero, região de procedência, estado civil, escolaridade e nível socioeconômico.

Em relação à idade dos pais participantes, no momento da entrevista, o que se observa na Tabela 1, numa análise intergrupos, é que em relação à faixa etária dos 20 aos 29 anos houve uma predominância do G1 sobre os Grupos G2 e G3; na faixa etária de 30 a 49 anos, o G1 foi menor em freqüência do que os Grupos G2 e G3, que estatisticamente apresentaram a mesma incidência e, quanto à faixa etária dos que tinham mais que 50 anos, a freqüência estatística foi igual para os três Grupos. 
Tabela 1 - Distribuição percentual dos participantes, segundo faixa etária e grupos estudados.

\begin{tabular}{|c|c|c|c|c|}
\hline \multirow{2}{*}{ GRUPO } & \multicolumn{4}{|c|}{ FAIXA ETÁRIA (\%) } \\
\hline & N\%/ SUJEITOS & ¿20/29 anos & $30 / 49$ anos & > 50anos \\
\hline G1 & 50 & $74,0 \subset C$ & 26,0 a $B$ & 0,0 a $A$ \\
\hline G2 & 50 & $26,0 b B$ & $72,0 b C$ & 2,0 a $A$ \\
\hline G3 & 50 & 0,0 a $A$ & $92,0 b B$ & 8,0 a $A$ \\
\hline TOTAL & 150 & 33,4 & 63,3 & 3,3 \\
\hline
\end{tabular}

A Tabela 2 refere-se ao gênero dos participantes deste estudo. Como se observa nesta tabela, a análise estatística indicou uma predominância do gênero feminino sobre o gênero masculino, nos três Grupos estudados.

Tabela 2 - Distribuição percentual dos participantes, segundo gênero e grupos estudados.

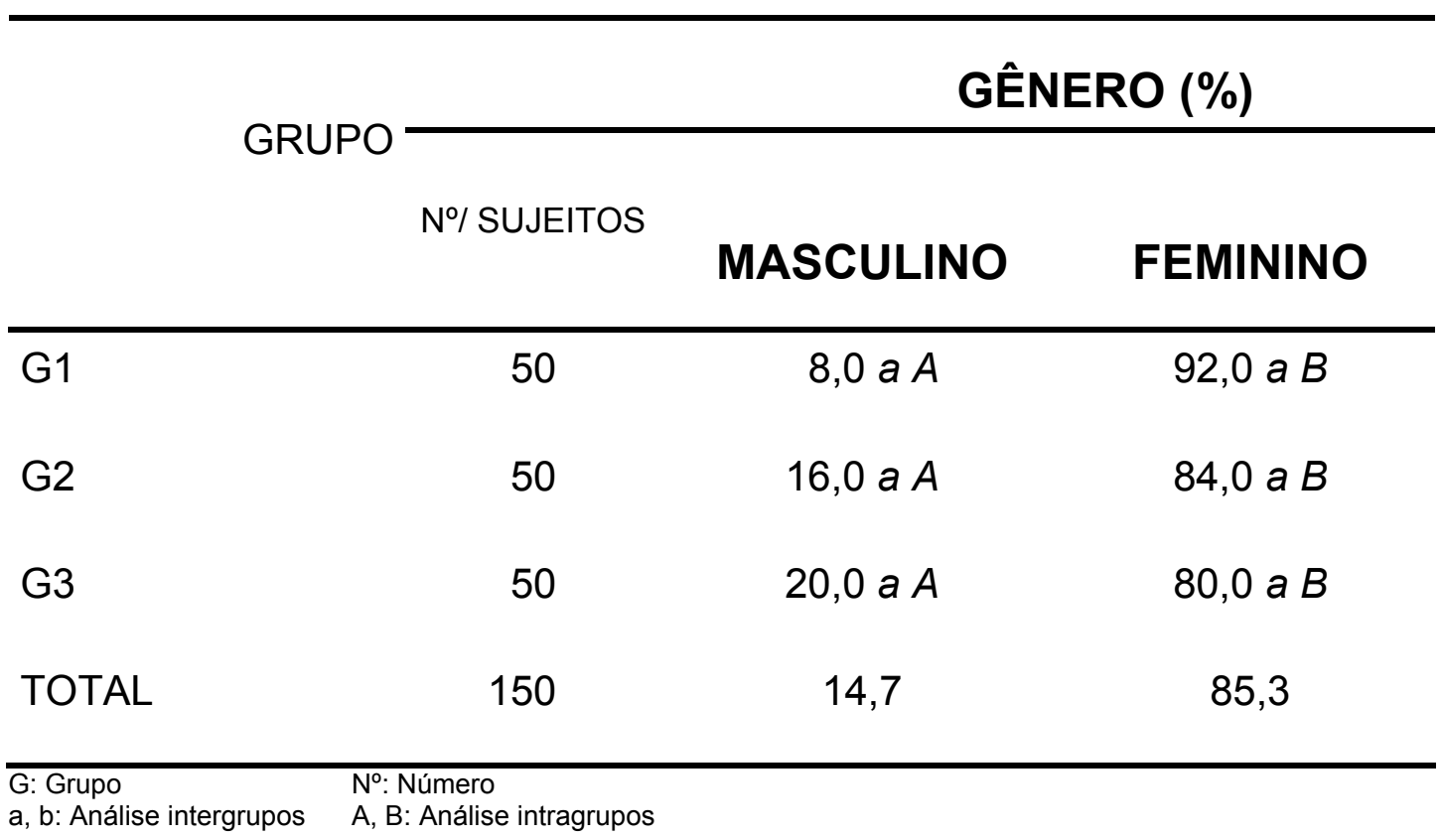


A Tabela 3 demonstra que da região sudeste procede a maioria dos pais entrevistados, sendo que, dos três Grupos estudados, o G1 é aquele que estatisticamente apresenta uma superioridade sobre o G2 e G3 na freqüência que se refere a procedência relativa aos estados do Sudeste. A análise estatística indica que a predominância da região sudeste sobre as outras regiões é significante para os Grupos G1 e G3, não havendo esta diferença para o Grupo G2.

Tabela 3 - Distribuição percentual dos participantes, segundo região de procedência e grupos estudados.

GRUPO

REGIÃO DE PROCEDÊNCIA (\%)

No/ SUJEITOS

SUDESTE OUTRAS REGIÕES

\begin{tabular}{lccc}
\hline G1 & 50 & 92,0 b B & 8,0 a $A$ \\
G2 & 50 & 60,0 a $A$ & $40,0 b \mathrm{~b}$ \\
G3 & 50 & 70,0 a B & $30,0 b \mathrm{~b}$ \\
TOTAL & 150 & 74,0 & 26,0 \\
$\begin{array}{l}\text { G: Grupo } \\
\text { No: Número } \\
\text { a: b: Análise intergrupos } \\
\text { A: B: Análise intragrupos }\end{array}$ & & &
\end{tabular}

A Tabela 4 que se refere ao estado civil dos pais entrevistados demonstra que existe, estatisticamente, uma condição de igualdade em todos os Grupos estudados, havendo uma predominância do estado civil casado sobre os outros estados civis, que incluem: solteiros, separados e viúvos. 
Tabela 4 - Distribuição percentual dos participantes, segundo estado civil e grupos estudados.

GRUPO _ ESTADO CIVIL (\%)

No/ SUJEITOS

\begin{tabular}{lccc} 
& & CASADO & OUTRO \\
\hline G1 & 50 & 74,0 a B & 26,0 a $A$ \\
G2 & 50 & 74,0 a B & 26,0 a $A$ \\
G3 & 50 & 82,0 a B & 18,0 a $A$ \\
TOTAL & 150 & 76,6 & 23,4 \\
$\begin{array}{l}\text { G: Grupo } \\
\text { No: Número } \\
\text { a, b: Análise intergrupos } \\
\text { A, B: Análise intragrupos }\end{array}$ & & &
\end{tabular}

A Tabela 5 demonstra que quanto à escolaridade dos pais participantes, foi estatisticamente comprovado, que os Grupos G1, G2 e G3 não diferem entre si para todos os níveis de escolaridade. O que deve ser ressaltado é que nos três Grupos o índice da condição de sem instrução é menor, estatisticamente significante, que os níveis de instrução de $1^{\circ} \mathrm{grau}$ e de $2^{\circ}$ e $3^{\circ}$ graus, sendo estes dois últimos, iguais entre si. 
Tabela 5 - Distribuição percentual dos participantes, segundo escolaridade e grupos estudados.

\begin{tabular}{|c|c|c|c|c|}
\hline \multirow{2}{*}{ GRUPO } & \multicolumn{4}{|c|}{ ESCOLARIDADE (\%) } \\
\hline & N\%/ SUJEITOS & $S / l$ & $1^{\circ} \mathrm{grau}$ & $2^{\circ}$ e $3^{\circ}$ graus \\
\hline G1 & 50 & 4,0 a $A$ & 52,0 a $B$ & 44,0 a $B$ \\
\hline G2 & 50 & 2,0 a $A$ & 52,0 a $B$ & 46,0 a $B$ \\
\hline G3 & 50 & 2,0 a $A$ & 62,0 a $B$ & 36,0 a $B$ \\
\hline TOTAL & 150 & 2,7 & 55,3 & 42,0 \\
\hline $\begin{array}{l}\text { S/l: Sem instruçã } \\
\text { G: Grupo }\end{array}$ & $\begin{array}{l}\text { a, b: Análise int } \\
\text { №: Número }\end{array}$ & & agrupos & \\
\hline
\end{tabular}

Considerando o nível socioeconômico dos pais participantes, observa-se na Tabela 6 que existe, estatisticamente, uma condição de igualdade em todos os Grupos estudados, havendo uma predominância do nível econômico baixo sobre o nível econômico médio.

Tabela 6 - Distribuição percentual dos participantes, segundo o nível socioeconômico e grupos estudados.

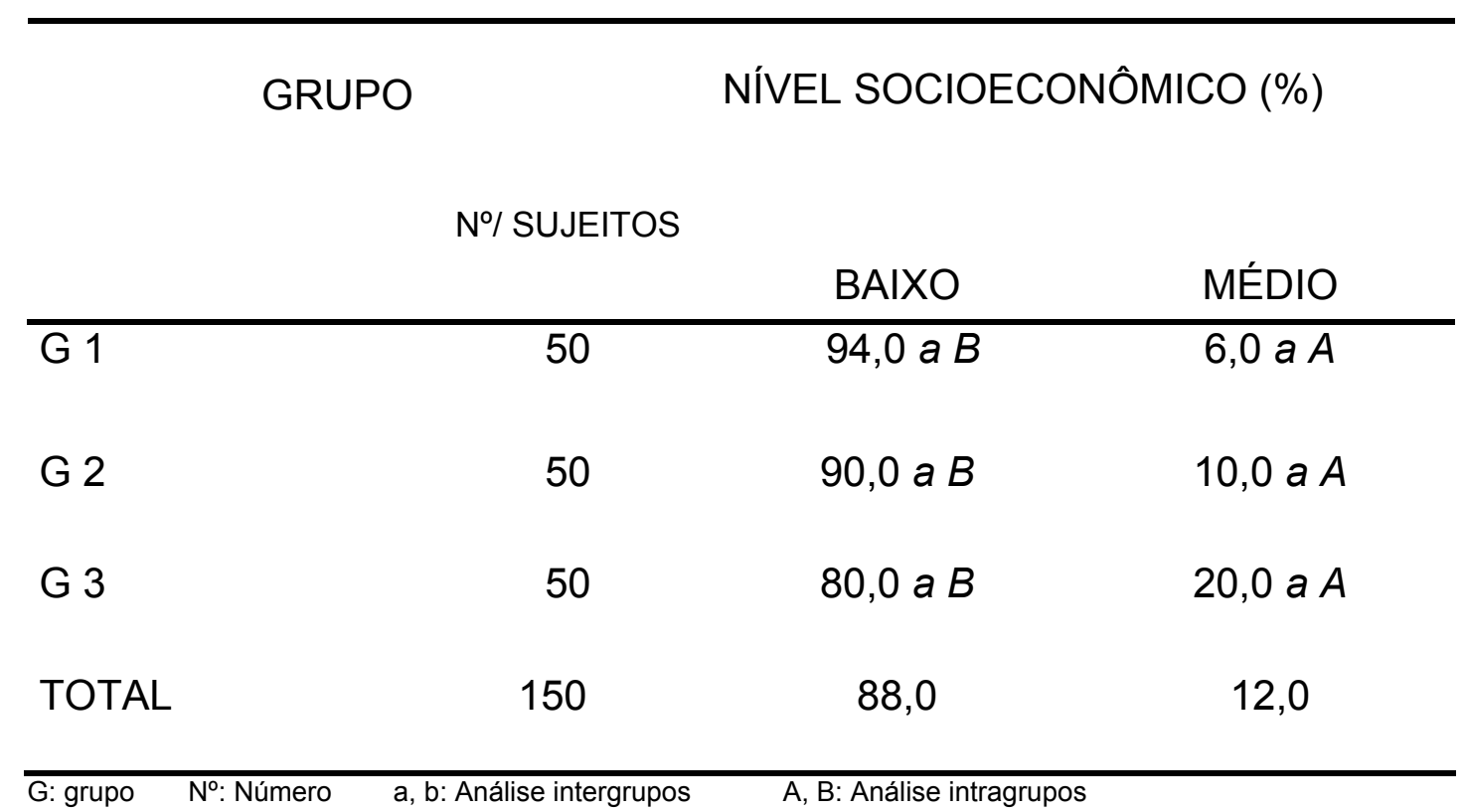




\subsection{A fissura labiopalatina e suas implicações.}

A segunda parte do instrumento utilizado para a coleta de dados teve a preocupação de enfocar informações pertinentes aos objetivos estabelecidos, buscando conhecer qual o significado e a influência da fissura labiopalatina nas vivências próprias do sujeito e de sua família, em cada faixa etária estipulada, os sentimentos experienciados pelos pais, a forma de lidarem com estes sentimentos, a rede de apoio buscada para a facilitação do enfrentamento e os fatores determinantes de suas atitudes de enfrentamento.

A participação da criança de zero a dois anos de idade na vida dos pais, freqüentando com eles a maioria dos lugares, pode ser considerada como uma atividade própria desta faixa etária, assim como a freqüência à escola para uma criança de seis a oito anos e o entrosamento e vivência com grupos de amigos para o período da adolescência. Assim sendo, o instrumento utilizado por este estudo buscou conhecer como estas atividades aconteciam na população estudada e se esta vivência, própria de cada faixa etária, teria sido dificultada pela existência da fissura labiopalatina. Os dados coletados sobre estas informações estão a seguir especificados nas Tabelas 7 e 8. 
A Tabela 7 revela que os pais participantes dos Grupos G1, G2 e G3, em sua grande maioria, expõem seus filhos às situações de participação em atividades que são pertinentes às suas respectivas faixas etárias.

A análise estatística mostrou que, em relação à questão que se refere à exposição do filho(a) em situações condizentes com as suas respectivas faixas etárias, as freqüências de respostas dos Grupos são predominantemente positivas. Destaca-se significativamente entre eles o Grupo G2, que apresentou maior nível de significância tanto na análise intergrupos, quanto na análise da característica avaliada (sim, para freqüência à escola).

Tabela 7 - Distribuição percentual dos participantes, segundo a questão da exposição de seus filhos em situações condizentes com suas respectivas faixas etárias.

\begin{tabular}{|c|c|c|c|c|c|c|c|}
\hline \multirow[t]{2}{*}{ GRUPO } & \multicolumn{3}{|c|}{$\begin{array}{c}\text { Saída/pais } \\
(\%)\end{array}$} & \multicolumn{2}{|c|}{$\begin{array}{l}\text { Freqüência/escola } \\
\qquad(\%)\end{array}$} & \multicolumn{2}{|c|}{$\begin{array}{c}\text { Grupo/amigos } \\
(\%)\end{array}$} \\
\hline & $\begin{array}{c}\text { No/ } \\
\text { SUJEITOS }\end{array}$ & SIM & NÃO & SIM & NÃO & SIM & NÃO \\
\hline G1 & 50 & $84,0 a B$ & $16,0 b A$ & & & & \\
\hline G2 & 50 & & & $98,0 b B$ & $2,0 a A$ & & \\
\hline G3 & 50 & & & & & $86,0 a B$ & $14,0 b A$ \\
\hline TOTAL & 150 & 28,0 & 5,4 & 32,7 & 0,6 & 28,7 & 4,6 \\
\hline
\end{tabular}

G: grupo

No: Número

a, b: Análise intergrupos

A, B: Análise intragrupos 
A Tabela 8 demonstra que os pais participantes pertencentes aos Grupos G1, G2 e G3 referem-se principalmente a não existência de dificuldades provocadas pela fissura labiopalatina nos dois primeiros anos de vida, quando ela ainda não foi operada, no período escolar e na adolescência. Assim, observa-se nesta tabela, que de modo estatisticamente significativo os pais negaram a existência da influência desta fissura nas experiências de saída com os pais, freqüência à escola e saída com amigos.

Tabela 8 - Distribuição percentual dos participantes, segundo o reconhecimento de influência da fissura labiopalatina para seus filhos nas situações condizentes com suas respectivas faixas etárias.

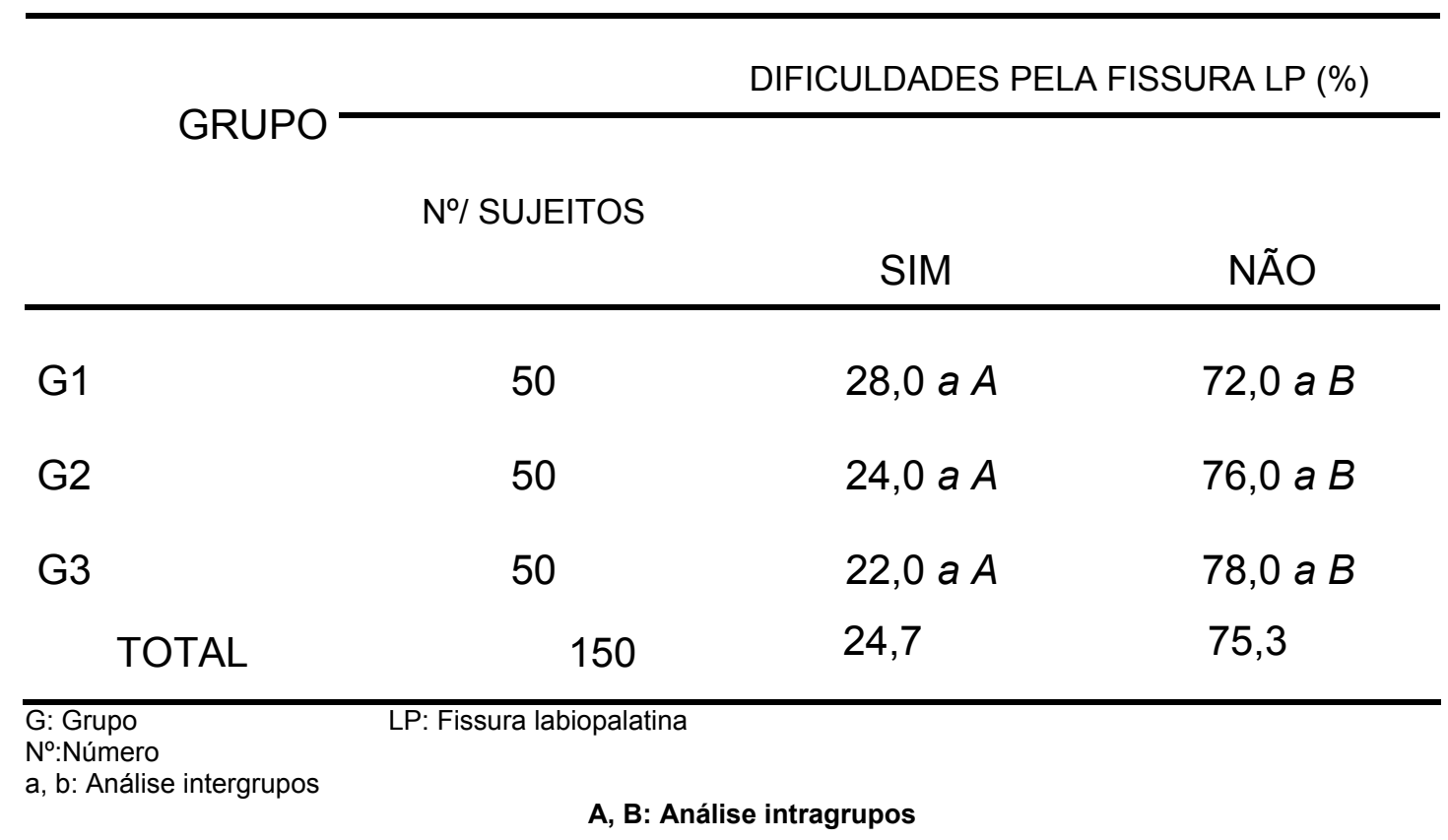

Com a possibilidade de múltipla escolha foi oferecido aos pais participantes um rol de 30 sentimentos, para que pudessem escolher aqueles com os quais se identificassem quando pensam na condição de seus filhos, sendo os dados categorizados em sentimentos negativos e positivos. Nas Tabelas 9 e 10, observa-se a análise estatística que compara a identificação 
dos três diferentes Grupos pelos respectivos sentimentos. Nas Figuras 1 e 2, podem ser observadas as escolhas feitas por cada Grupo, para cada sentimento, de forma específica.

A Tabela 9, demonstra que existe uma diferença significativa, entre o Grupo G1 com os Grupos G2 e G3, indicando que o Grupo G1 experiencia um total de sentimentos negativos, estatisticamente significante, superior aos outros dois Grupos.

Tabela 9 - Distribuição dos participantes, segundo medidas descritivas das freqüências de respostas sobre os sentimentos negativos.

\begin{tabular}{lccc}
\hline \multirow{2}{*}{$\begin{array}{c}\text { MEDIDA } \\
\text { DESCRITIVA }\end{array}$} & \multicolumn{3}{c}{ SENTIMENTOS NEGATIVOS } \\
\cline { 2 - 4 } & G1 & GRUPOS \\
\cline { 2 - 4 } & 0,0 & 0,0 & G3 \\
\hline Valor Mínimo & $3,0 b$ & 1,0 a & 0,0 \\
Mediana & 14,0 & 10,0 & $1,0 a$ \\
Valor Máximo & 4,1 & 2,2 & 10,0 \\
Média & 3,5 & 2,4 & 2,2 \\
$\begin{array}{l}\text { Desvio-padrão } \\
\text { p<0,01 }\end{array}$ & & & 2,7 \\
$\begin{array}{l}\text { G: grupo } \\
\text { a, b: Análise intergrupos }\end{array}$ & & &
\end{tabular}


$\mathrm{Na}$ Figura 1 observa-se que no rol dos sentimentos negativos que foram oferecidos com possibilidade de múltipla escolha aos participantes, tevese uma prevalência maior do Grupo G1 sobre os dois grupos, na maioria dos sentimentos especificados. Esta prevalência destaca-se principalmente nos sentimentos de desespero, medo, insegurança e carência.

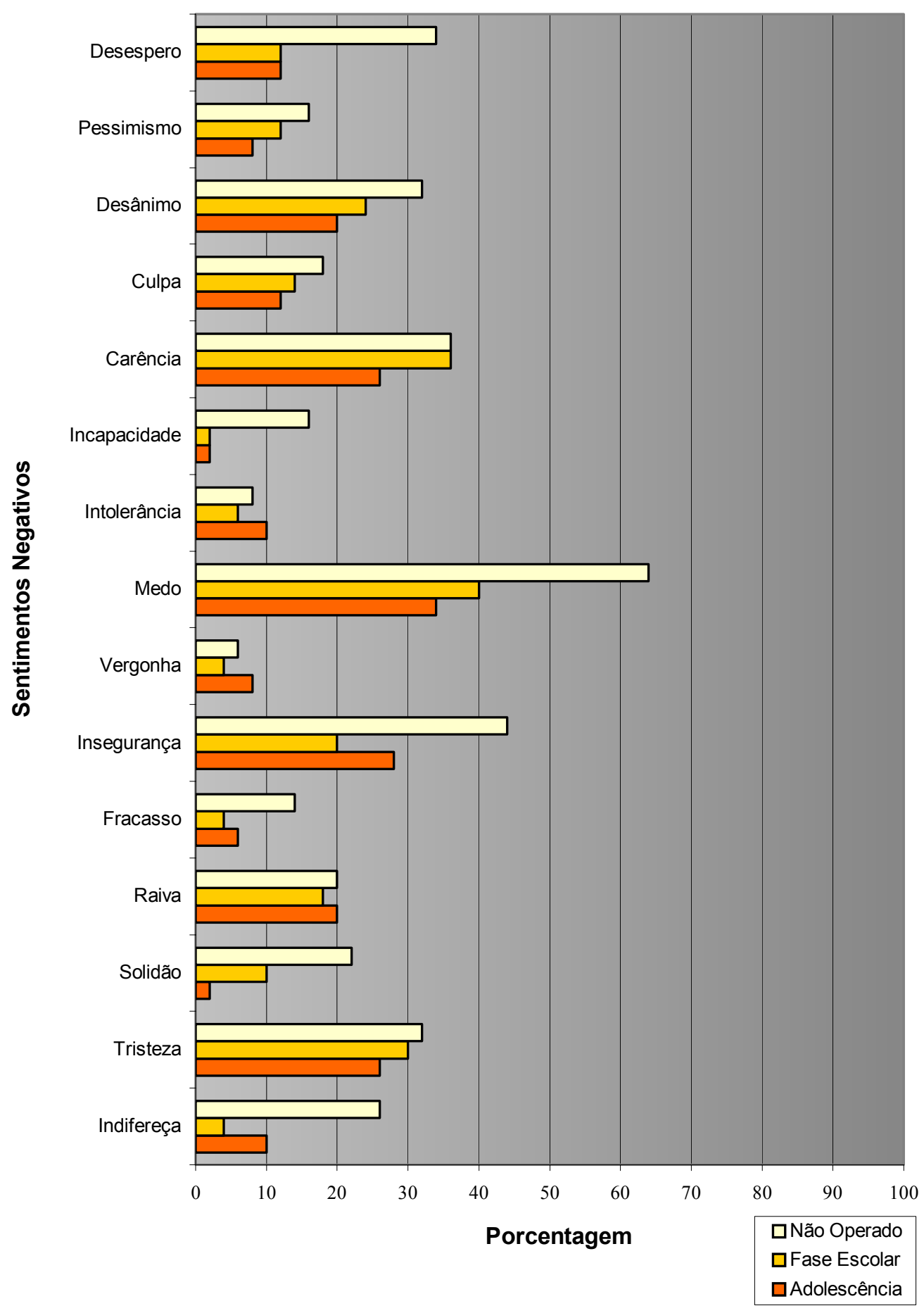


Figura 1- Distribuição percentual dos participantes, segundo os sentimentos negativos identificados nas situações condizentes com as respectivas faixas etárias de seus filhos. 
Na Tabela 10, observa-se que não existe diferenciação entre os Grupos G1, G2 e G3, indicando que todos os Grupos identificam um total de sentimentos positivos similares entre si.

Tabela 10 - Distribuição dos participantes, segundo medidas descritivas das freqüências de respostas sobre os sentimentos positivos.

\begin{tabular}{|c|c|c|c|}
\hline \multirow{3}{*}{ DESCRITIVA } & \multicolumn{3}{|c|}{ SENTIMENTOS POSITIVOS } \\
\hline & \multicolumn{3}{|c|}{ GRUPOS } \\
\hline & G1 & G2 & G3 \\
\hline Valor Mínimo & 6,0 & 6,0 & 4,0 \\
\hline Mediana & 13,5 & 14,0 & 14,0 \\
\hline Valor Máximo & 15,0 & 15,0 & 15,0 \\
\hline Média & 13,0 & 13,4 & 13,0 \\
\hline Desvio-padrão & 2,1 & 2,3 & 2,5 \\
\hline
\end{tabular}

Como é possível visualizar na Figura 2, os Grupos 1, 2 e 3 na identificação com sentimentos positivos, tiveram uma preferência similar, não havendo entre eles diferenças significativas. Porém, observa-se que para o Grupo G1 os sentimentos "calma" e "tranqüilidade" aparecem numa porcentagem menor do que para os outros Grupos. Pode-se destacar, também, que o Grupo G2 aparece em freqüências maiores, na maioria dos sentimentos identificados, quando comparado com os Grupos G1 e G3. 


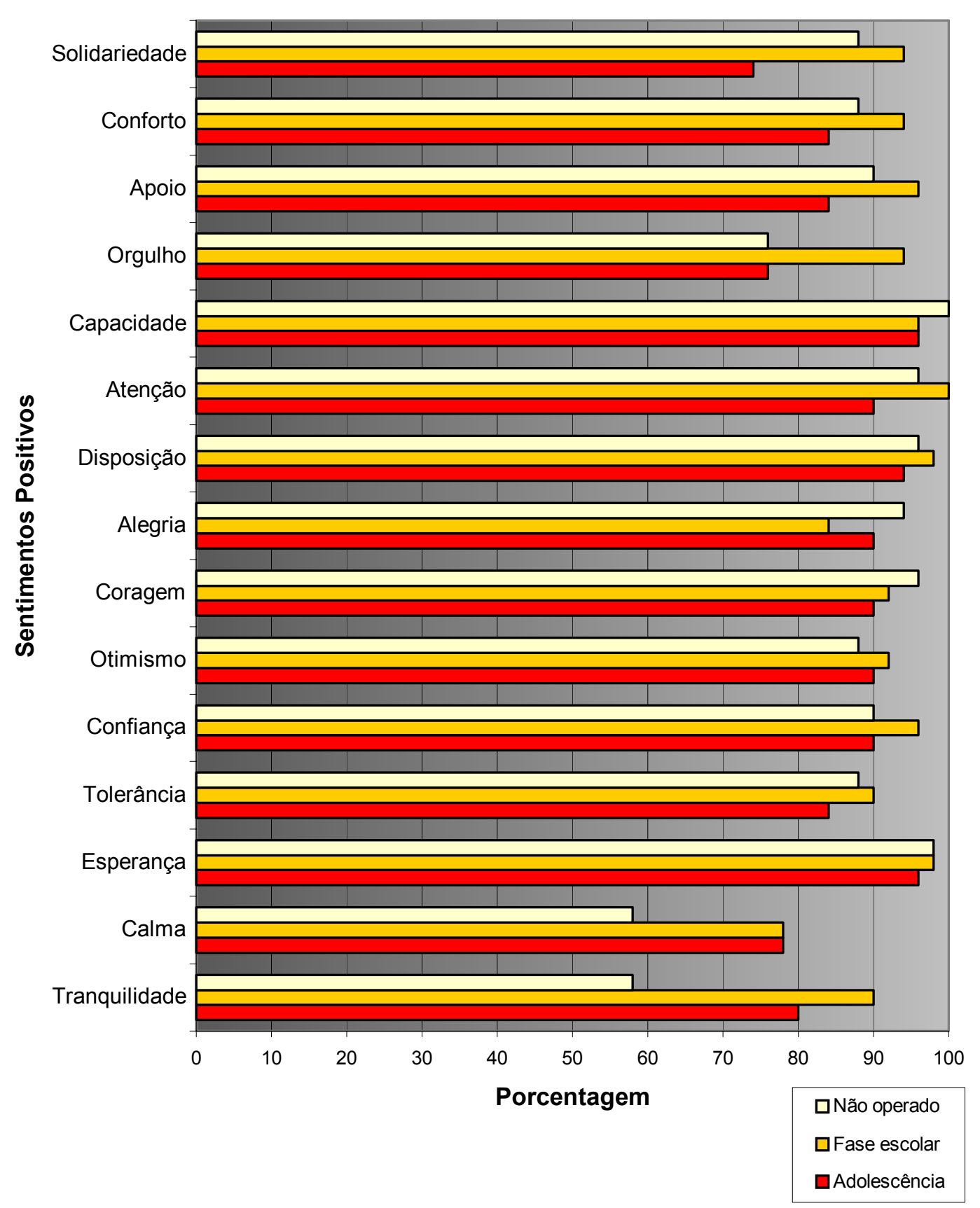

Figura - 2 Distribuição percentual dos participantes, segundo os sentimentos positivos identificados nas situações condizentes com as respectivas faixas etárias de seus filhos. 
Os pais participantes deste estudo foram também indagados sobre a forma de lidarem com os sentimentos experienciados. As opções por eles escolhidas foram agrupadas em duas categorias: A) forma positiva de se lidar com os sentimentos experienciados (não evitação de reuniões familiares e sociais, busca de familiares e amigos e continuidade do modo de vida sem mudanças ou alterações); B) forma negativa de se lidar com os sentimentos experienciados (isolamento de tudo e de todos, evitação de reuniões familiares e sociais, evitação de levar a criança em locais de pessoas estranhas). Tabelas 11 e 12 , respectivamente.

As Tabelas 11 e 12 mostram que os Grupos G1, G2 e G3 não apresentaram diferenciação estatisticamente significativa entre si, em relação ao modo de lidar, positivamente ou negativamente com os sentimentos experenciados.

Tabela 11 - Distribuição dos participantes, segundo medidas descritivas das freqüências de respostas sobre a forma positiva de lidar com os sentimentos experienciados.

\begin{tabular}{lccc}
\hline & \multicolumn{3}{c}{ TOTAL DE ATITUDES POSITIVAS } \\
\cline { 2 - 4 } $\begin{array}{c}\text { MEDIDA } \\
\text { DESCRITIVA }\end{array}$ & G1 & GRUPOS & G3 \\
\cline { 2 - 4 } & 0,0 & 2,0 & 3,0 \\
Valor Mínimo & 4,0 & 4,0 & 4,0 \\
Mediana & 4,0 & 4,0 & 4,0 \\
Valor Máximo & 3,5 & 3,7 & 3,8 \\
Média & 0,9 & 0,6 & 0,4 \\
Desvio-padrão & G: grupo & &
\end{tabular}


Tabela 12 - Distribuição dos participantes, segundo medidas descritivas das freqüências de respostas sobre a forma negativa de lidar com os sentimentos experienciados.

\begin{tabular}{lccc}
\hline & \multicolumn{2}{c}{ TOTAL DE ATITUDES NEGATIVAS } \\
\cline { 2 - 4 } MESIDA & \multicolumn{3}{c}{ GRUPOS } \\
\cline { 2 - 4 } & G1 & G2 \\
\hline Valor Mínimo & 0,0 & 0,0 & 0,0 \\
Mediana & 0,0 & 0,0 & 0,0 \\
Valor Máximo & 4,0 & 3,0 & 3,0 \\
Média & 0,6 & 0,3 & 0,3 \\
$\begin{array}{l}\text { Desvio-padrão } \\
\text { p }>0,05\end{array}$ & 1,2 & 0,7 & 0,7 \\
G: Grupo & & &
\end{tabular}

Na Figura 3, observa-se uma semelhança entre os Grupos G1, G2 e G3, na identificação com opções consideradas positivas sobre a forma de lidar com os sentimentos experienciados., evidencia-se que o Grupo G1 obteve valores menores que os outros dois Grupos para a maioria das formas que foram consideradas positivas. 
Legenda: 1- Não evitação de reuniões familiares

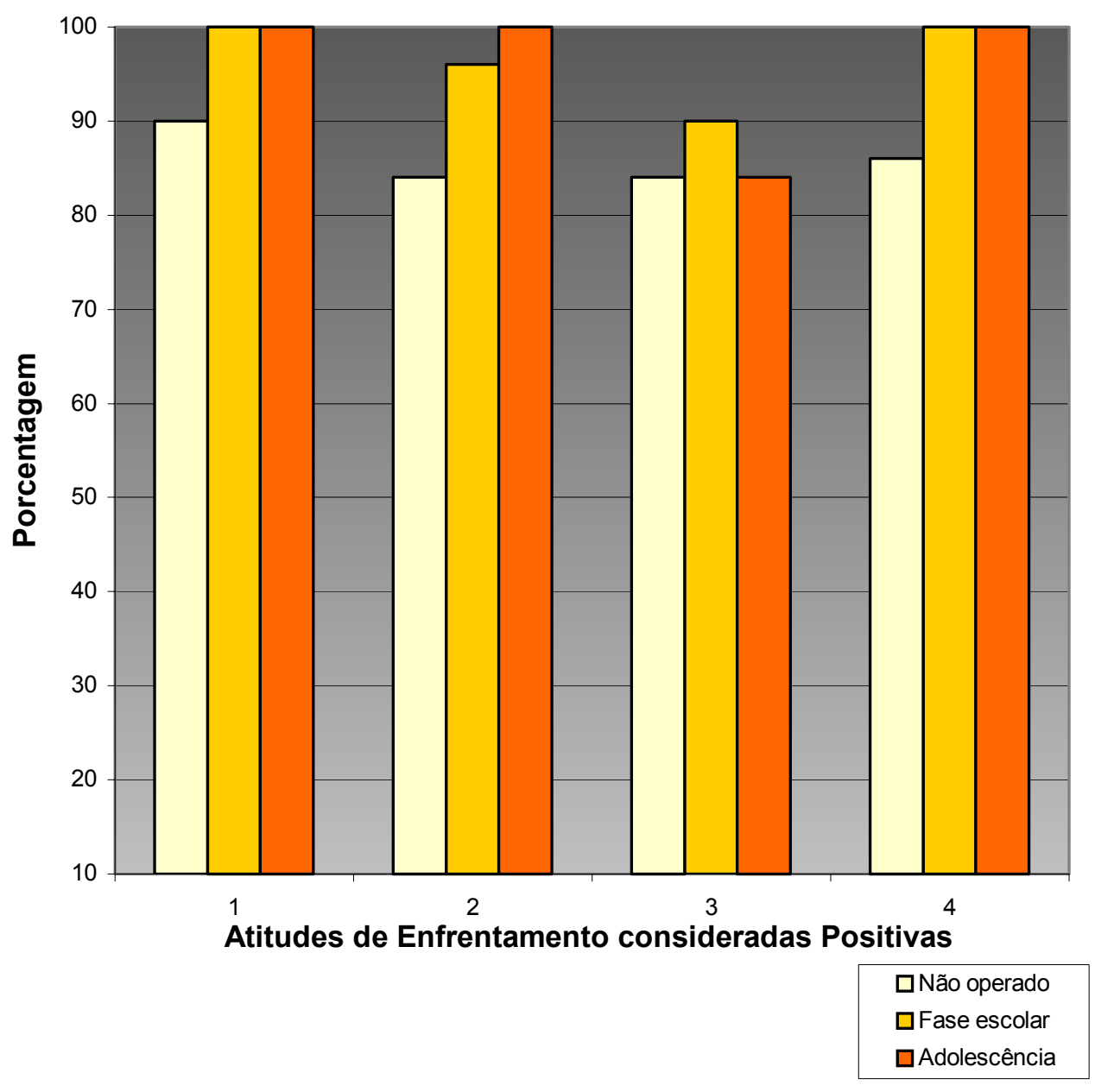

2- Não evitação de reuniões sociais

3- Busca de amigos e familiares

4-Continuidade à rotina de vida anterior.

Figura 3 - Distribuição percentual dos participantes, segundo a forma, considerada positiva, de lidar com os sentimentos experienciados.

$\mathrm{Na}$ Figura 4 pode-se observar que os Grupos G1, G2 e G3 se assemelham na identificação com opções consideradas negativas sobre a forma de lidar com os sentimentos experienciados. No entanto, observa-se, também, que o Grupo G1 tem valores maiores que os outros dois Grupos para 
todas as possibilidades que foram consideradas negativas. Ressalta-se que a maior porcentagem encontrada neste Grupo refere-se à opção de não freqüência com a criança de locais em que se encontram pessoas estranhas. $O$ Grupo G2 não apresentou nenhuma indicação na opção de evitar reuniões familiares.

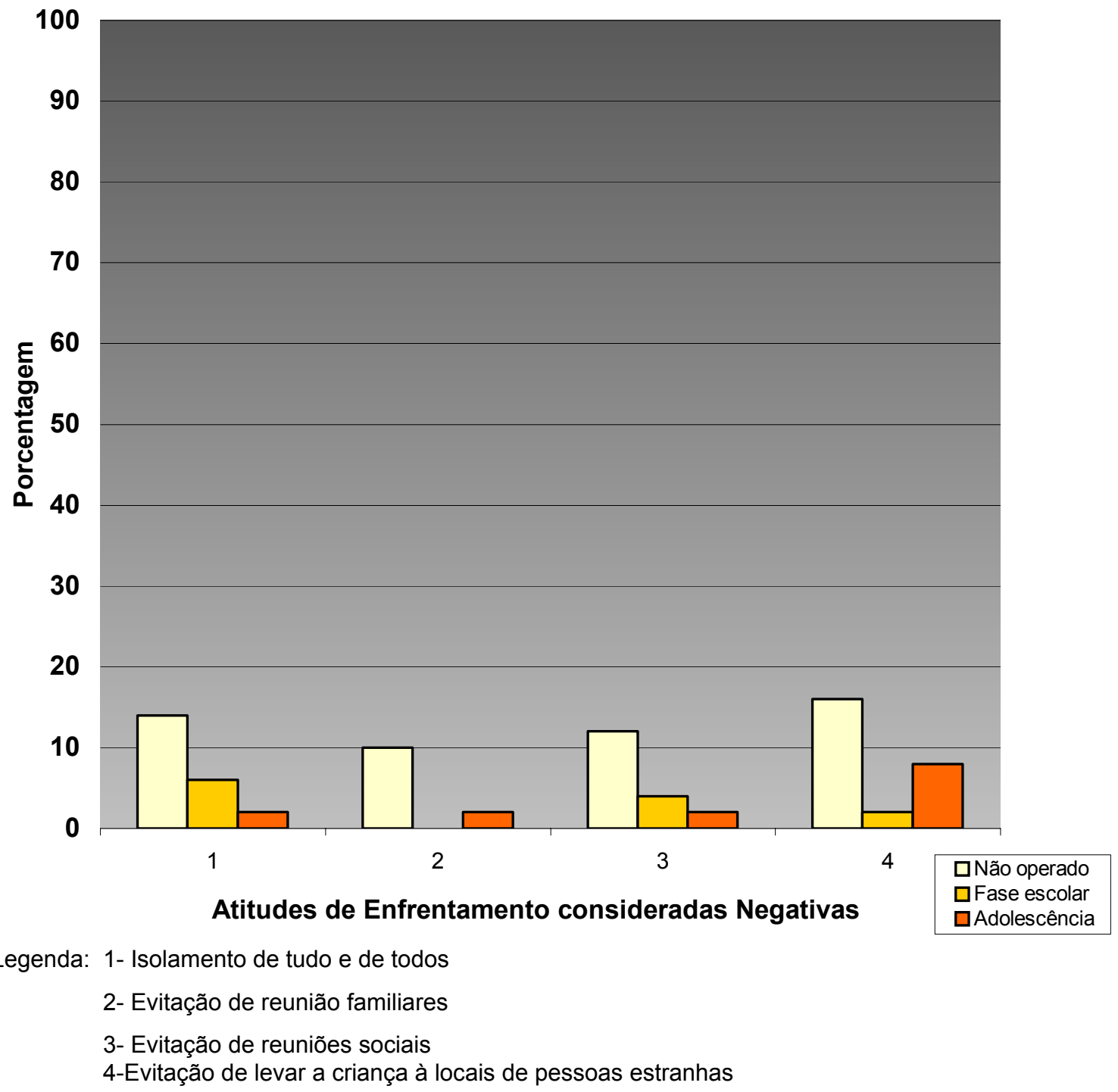

Figura 4 - Distribuição percentual dos participantes, segundo a forma, considerada negativa, de lidar com os sentimentos experienciados. 
Os pais participantes foram, também, questionados sobre a rede de apoio por eles utilizada para serem auxiliados nas situações de enfrentamento e nas vivências com seus filhos. As opções oferecidas foram, tabuladas e congregadas em duas categorias: A) busca de apoio individual (vivência religiosa, passeios, leituras, profissionais específicos), B) busca de apoio coletivo (todos os tipos de apoio, grupos, apoio familiar e social), conforme demonstram as Tabelas 13 e 14.

A análise quantitativa dos dados revelados nas Tabelas 13 e 14 revela que, os Grupos G1, G2 e G3 não apresentaram diferenciação estatisticamente significativa entre si, na busca de apoio considerado individual elou coletivo.

Tabela 13 - Distribuição dos participantes, segundo a busca de apoio considerado individual.

\begin{tabular}{lccc}
\hline & \multicolumn{3}{c}{$\begin{array}{c}\text { ATITUDES DE ENFRENTAMENTO } \\
\text { MESCA NO INDIVIDUAL }\end{array}$} \\
\cline { 2 - 4 } DESCRITIVA & G1 & GRUPOS & G3 \\
\cline { 2 - 4 } & 0,0 & 1,0 & 1,0 \\
Valor Mínimo & 3,0 & 3,0 & 3,0 \\
Mediana & 4,0 & 4,0 & 4,0 \\
Valor Máximo & 2,5 & 2,7 & 2,8 \\
Média & 1,2 & 1,0 & 1,0 \\
$\begin{array}{l}\text { Desvio-padrão } \\
\text { p }>0,05 \\
\text { G: grupo }\end{array}$ & & &
\end{tabular}


Tabela 14 - Distribuição dos participantes, segundo a busca de apoio, considerado coletivo.

\begin{tabular}{lccc}
\hline \multirow{2}{*}{$\begin{array}{l}\text { MEDIDA } \\
\text { DESCRITIVA }\end{array}$} & \multicolumn{3}{c}{$\begin{array}{c}\text { ATITUDES DE ENFRENTAMENTO } \\
\text { BUSCA NO COLETIVO }\end{array}$} \\
\cline { 2 - 4 } & G1 & G2 & G3 \\
\hline Valor Mínimo & 1,0 & 0,0 & 0,0 \\
Mediana & 2,0 & 2,0 & 2,0 \\
Valor Máximo & 3,0 & 3,0 & 3,0 \\
Média & 1,9 & 1,8 & 1,9 \\
$\begin{array}{l}\text { Desvio-padrão } \\
\text { p }>0,05 \\
\text { G: grupo }\end{array}$ & 0,5 & 0,6 & 0,7 \\
\hline
\end{tabular}

A Figura 5 revela as escolhas feitas pelos pais participantes, em relação ao apoio individual, para melhor enfrentamento das situações consideradas difíceis e delicadas. Nesta Figura pode-se observar que as opções "vivência religiosa, procura de todo o tipo de apoio e a busca de informações com profissionais e leituras específicas" tiveram porcentagens superiores à opção "sair para passear". Ressalta-se que a busca de entretenimento foi a opção de menor porcentagem para os pais entrevistados. 


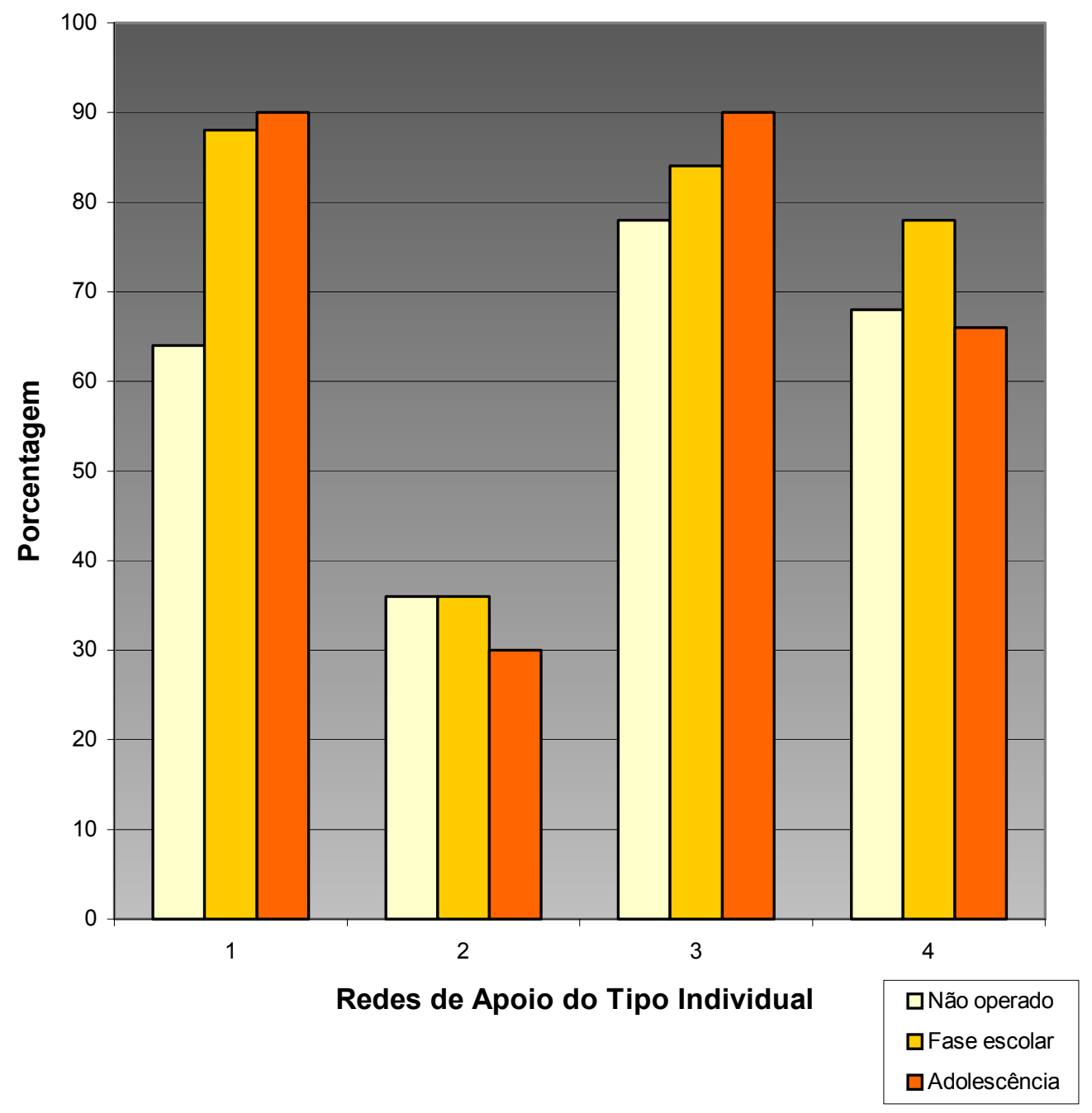

Legenda: 1- Vivência religiosa

2- Sair para passear

3- Buscar informações com profissionais e leituras específicas

4- Procurar todo o tipo de apoio

Figura 5 - Distribuição percentual dos participantes, segundo a busca de rede de apoio individual. 
A Figura 6 refere-se às opções de apoio coletivo, para ajudarem os pais participantes deste estudo no enfrentamento de situações experienciadas pelos mesmos, nas respectivas faixas etárias consideradas neste estudo.

A visualização desta Figura permite observar que a opção que se refere à condição de "não fazer nada de especial" foi uma escolha indicada apenas pelos participantes do Grupo G1. Este mesmo grupo apresentou porcentagens inferiores aos Grupos G2 e G3 nas opções "fazer parte de grupos de apoio e contar com o apoio do cônjuge e dos filhos". No entanto, no que se refere à opção de "busca de apoio com familiares em geral" o G1 foi o grupo que indicou maior preferência para este tipo de suporte. 


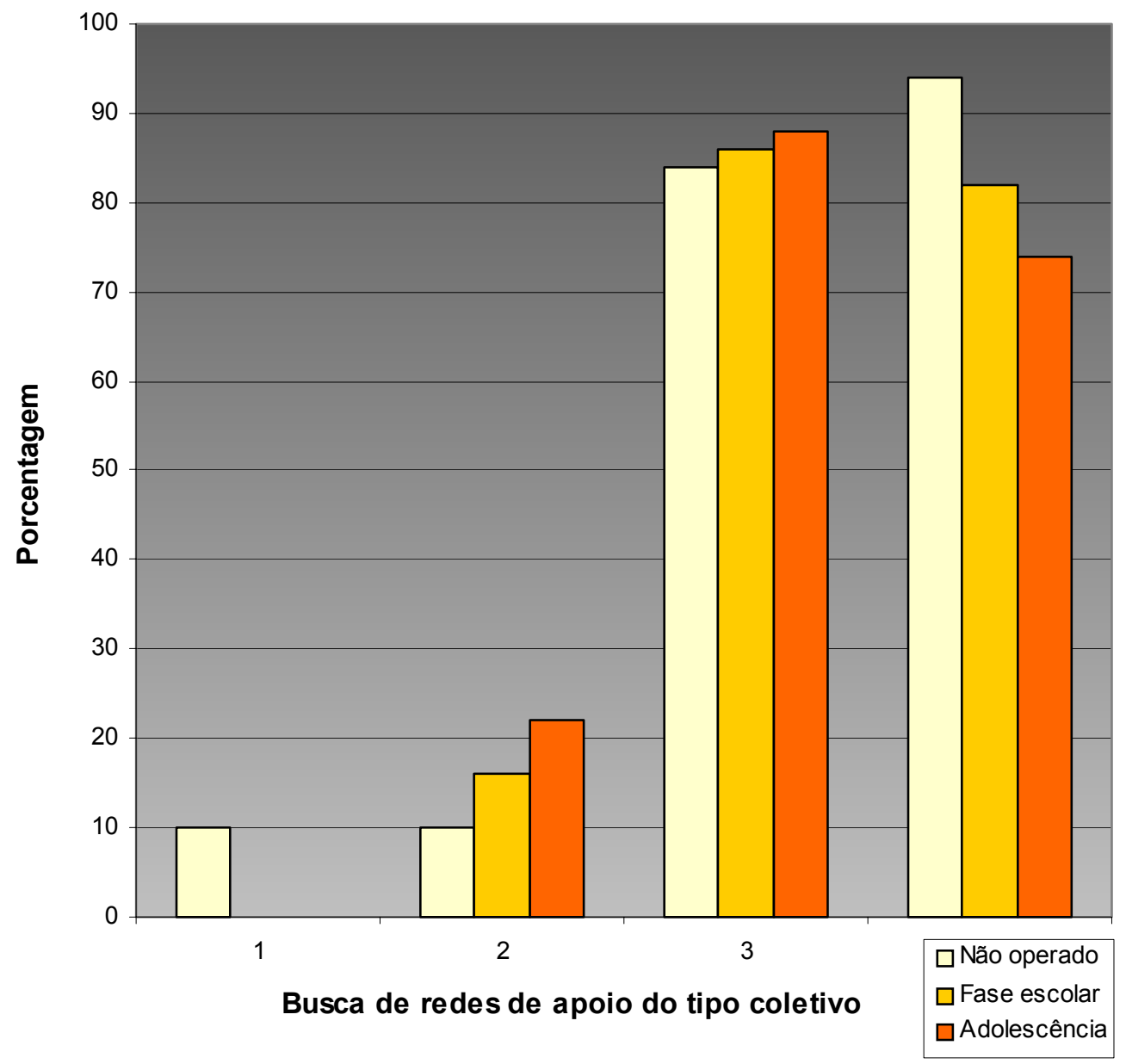

Legenda: 1- Não fazer nada de especial

2- Fazer parte de grupos de apoio

3- Contar com o apoio do marido e filhos

4- Contar com o apoio de familiares em geral

Figura 6 - Distribuição percentual dos participantes, segundo a busca de rede de apoio coletivo.

Este estudo também buscou identificar os fatores que determinaram as atitudes de enfrentamento utilizadas pelos pais nas situações pertinentes às faixas etárias previamente estabelecidas. As opções oferecidas que se referiam à maturidade, religiosidade e comodismo foram consideradas como determinantes internos, enquanto as opções que se referiam a incentivos, 
valores familiares e atendimentos realizados no HRAC foram incluídas como sendo determinantes externos.

As Tabelas 15 e 16 demonstram o resultado da análise estatística realizada com os dados obtidos sobre este enfoque, indicando que não houve diferença nas respostas entre os grupos.

Tabela 15 - Distribuição dos participantes, segundo o total de respostas relativas aos fatores internos que determinaram as atitudes de enfrentamento.

\begin{tabular}{lccc}
\hline \multirow{2}{*}{$\begin{array}{c}\text { MEDIDA } \\
\text { DESCRITIVA }\end{array}$} & \multicolumn{3}{c}{$\begin{array}{c}\text { DETERMINANTES DE ENFRENTAMENTO } \\
\text { FATORES INTERNOS }\end{array}$} \\
\cline { 2 - 4 } & G1 & G2 & G3UPOS \\
\hline & 1,0 & 1,0 & 1,0 \\
Valor Mínimo & 2,0 & 2,0 & 2,0 \\
Mediana & 3,0 & 3,0 & 3,0 \\
Valor Máximo & 1,9 & 1,9 & 1,9 \\
Média & 0,6 & 0,4 & 0,5 \\
Desvio-padrão & & & \\
\hline $\begin{array}{l}\text { p }>0,05 \\
\text { G: grupo }\end{array}$ & & &
\end{tabular}

Tabela 16 - Distribuição dos participantes, segundo o total de respostas relativas aos fatores externos que determinaram as atitudes de enfrentamento. 


\begin{tabular}{lccc}
\hline \multirow{2}{*}{$\begin{array}{c}\text { MEDIDA } \\
\text { DESCRITIVA }\end{array}$} & $\begin{array}{c}\text { DETERMINANTES DE ENFRENTAMENTO } \\
\text { FATORES EXTERNOS }\end{array}$ \\
\cline { 2 - 4 } & G1 & GRUPOS \\
\cline { 2 - 4 } & 1,0 & G2 & G3 \\
\hline Valor Mínimo & 3,0 & 0,0 & 0,0 \\
Mediana & 3,0 & 3,0 & 3,0 \\
Valor Máximo & 2,8 & 3,0 & 3,0 \\
Média & 0,5 & 2,5 & 2,6 \\
Desvio-padrão & & 0,8 & 0,8 \\
\hline p $>0,05$ & & &
\end{tabular}

Para melhor visualização das escolhas realizadas pelos participantes deste estudo, em relação aos fatores que determinaram as atitudes de enfrentamento, apresenta-se as Figuras 7 e 8.

A Figura 7 permite a visualização dos fatores internos que foram considerados determinantes para sustentar as atitudes de enfrentamento dos pais; destaca-se a identificação maior dos pais pertencentes aos Grupos G1, G2 e G3 para as opções que se referem à condição de maturidade e à vivência religiosa. Pode-se notar, também, que o Grupo G1 se atribuiu maior identificação com os fatores "imaturidade" e "comodismo". 


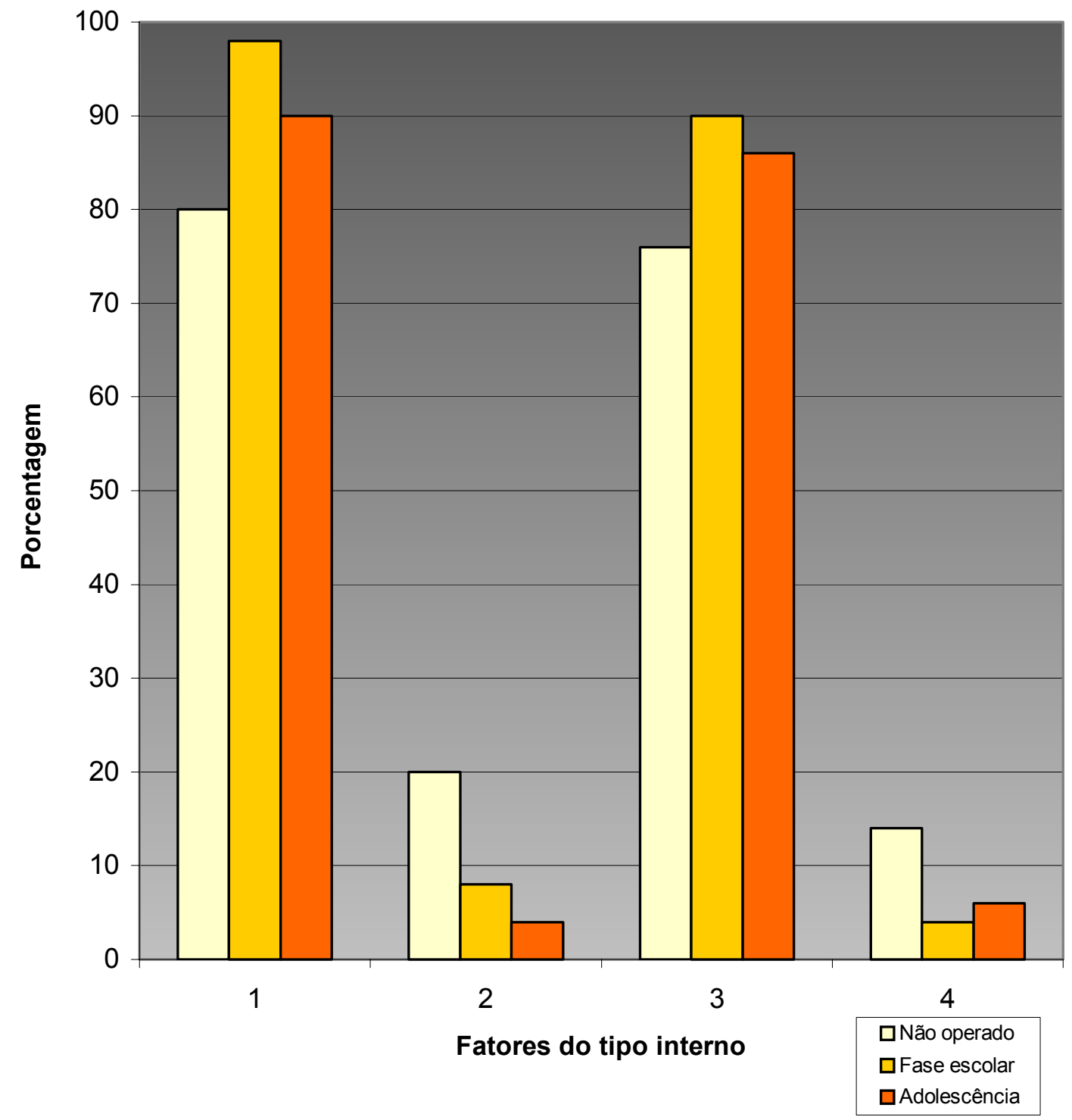

Legenda: 1-Maturidade
2- Imaturidade
3- Religiosidade
4- Comodismo

Figura 7- Distribuição percentual dos participantes, segundo as respostas relativas aos fatores, considerados do tipo interno, que determinaram as atitudes de enfrentamento. 
A Figura 8 demonstra os fatores externos que foram considerados pelos pais participantes deste estudo como responsáveis na sustentação de suas atitudes de enfrentamento. Nota-se a identificação maior dos pais pertencentes aos três grupos estudados pelos atendimentos prestados pelo HRAC, reconhecido por eles como sendo o facilitador do processo de enfrentamento. Ressalta-se que o grupo G1, apresenta maior porcentagem na opção que se refere ao recebimento de incentivos da família e/ou dos amigos.

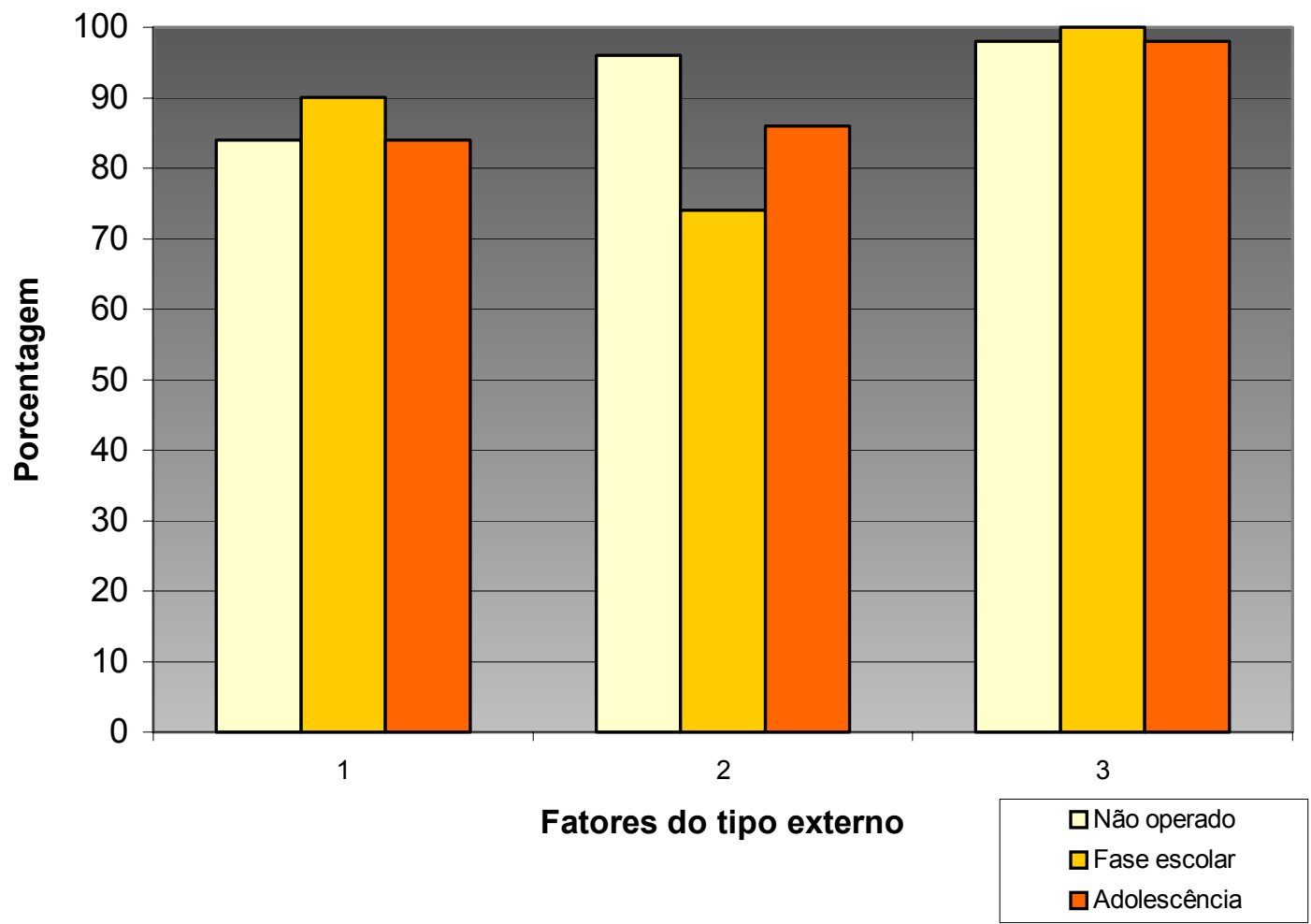

Legenda: 1- Valores familiares

2- Incentivo da família e ou amigos

3- Atendimento dos profissionais do Centrinho

Figura 8 - Distribuição percentual dos participantes, segundo as respostas relativas aos fatores considerados do tipo externo, que determinaram as atitudes de enfrentamento. 


\subsection{A influência da fissura labiopalatina na relação familiar.}

$\mathrm{Na}$ terceira parte do instrumento o enfoque foi direcionado para o conhecimento da influência da fissura labiopalatina na dinâmica familiar,

Considerando a família como um sistema onde todos os seus componentes são interdependentes e onde cada membro da família afeta outro membro, este estudo buscou identificar a possível influência da fissura labiopalatina no relacionamento familiar, conjugal e na relação de convivência com os irmãos sem fissura labiopalatina. Desta forma, as Tabelas seguintes referem-se a estes dados que foram também analisados estatisticamente.

A Tabela 17 revela que, não existiu diferença significativa entre aqueles participantes que reconheceram a existência da influência da fissura labiopalatina na família e aqueles que não identificaram a existência desta influência, em todos os grupos estudados.

Tabela 17- Distribuição percentual dos participantes, segundo a percepção destes, sobre a influência da fissura labiopalatina no relacionamento familiar.

\begin{tabular}{|c|c|c|c|}
\hline \multirow[t]{2}{*}{ GRUPO } & \multicolumn{3}{|c|}{ INFLUÊNCIA DA FISSURA LP NA FAMÍLIA } \\
\hline & N\%/ SUJEITOS & $\mathrm{NÃO}(\%)$ & $\operatorname{SIM}(\%)$ \\
\hline \multicolumn{4}{|l|}{ G1 } \\
\hline & 50 & 42,0 a $A$ & 58,0 a $A$ \\
\hline \multicolumn{4}{|l|}{ G2 } \\
\hline \multirow{2}{*}{ G3 } & 50 & 48,0 a $A$ & 52,0 a $A$ \\
\hline & 50 & 40,0 a $A$ & 60,0 a $A$ \\
\hline TOTAL & 150 & 43,0 & 57,0 \\
\hline $\begin{array}{l}\text { G: Grupo } \\
\text { No: Número } \\
\text { a: Análise intergrupos }\end{array}$ & LP: Lábiopal & & \\
\hline
\end{tabular}


Do total de cada Grupo que respondeu ter tido a existência da fissura labiopalatina uma influência no relacionamento familiar, buscou-se identificar se esta influência se caracterizava como uma condição de favorecimento ou de prejuízo na dinâmica familiar (Tabela 18). Notou-se que, apesar de todos os grupos identificarem a condição da influência da fissura labiopalatina no relacionamento familiar como desfavorável, somente para o G1 que esta identificação foi estatisticamente significante.

Tabela 18 - Distribuição percentual dos participantes, segundo a percepção destes, sobre a condição da influência da fissura labiopalatina no relacionamento familiar.

\begin{tabular}{|c|c|c|c|}
\hline \multirow[t]{2}{*}{ GRUPO } & \multicolumn{3}{|c|}{ INFLUÊNCIA DA FISSURA LP NA FAMÍLIA } \\
\hline & No/ SUJEITOS & PARA MELHOR (\%) & PARA PIOR (\%) \\
\hline G1 & 29 & 24,0 a $A$ & 76,0 a $B$ \\
\hline G2 & 26 & 46,0 a $A$ & 54,0 a $A$ \\
\hline G3 & 30 & 40,0 a $A$ & 60,0 a $A$ \\
\hline TOTAL & 85 & 36,5 & 63,5 \\
\hline
\end{tabular}

Do total dos pais participantes dos Grupos, que no momento da coleta de dados encontravam-se na condição civil de casado, este estudo indagou, para os mesmos sobre a influência da fissura labiopalatina de seus filhos no relacionamento conjugal (Tabela 19).

A análise estatística dos dados descritos nesta tabela revela que não existe diferença significativa entre os grupos. 
Tabela 19 - Distribuição percentual dos participantes, segundo a percepção destes, sobre a influência da fissura labiopalatina no relacionamento conjugal.

\begin{tabular}{|c|c|c|c|}
\hline \multirow[t]{2}{*}{ GRUPO } & & \multicolumn{2}{|c|}{$\begin{array}{c}\text { INFLUÊNCIA NO RELACIONAMENTO } \\
\text { CONJUGAL }\end{array}$} \\
\hline & N\%/ SUJEITOS & NÃO (\%) & $\operatorname{SIM}(\%)$ \\
\hline G1 & 40 & 52,5 a $A$ & 47,5 a $A$ \\
\hline G2 & 40 & 40,0 a $A$ & 60,0 a $A$ \\
\hline G3 & 43 & 46,5 a $A$ & 53,5 a $A$ \\
\hline TOTAL & 123 & 46,4 & 53,6 \\
\hline
\end{tabular}

Dos pais participantes, que reconheceram a influência da fissura labiopalatina de seus filhos no relacionamento conjugal, buscou-se conhecer se esta influência foi positiva ou negativa. As respostas obtidas estão descritas na Tabela 20, sendo observado que os três Grupos participantes apresentaram uma diferença significativa no reconhecimento de ter sido ser a influência da fissura labiopalatina de seus filhos favorável ao relacionamento conjugal. 
Tabela 20 - Distribuição percentual dos participantes, segundo a percepção destes, sobre a condição da influência da fissura labiopalatina no relacionamento conjugal.

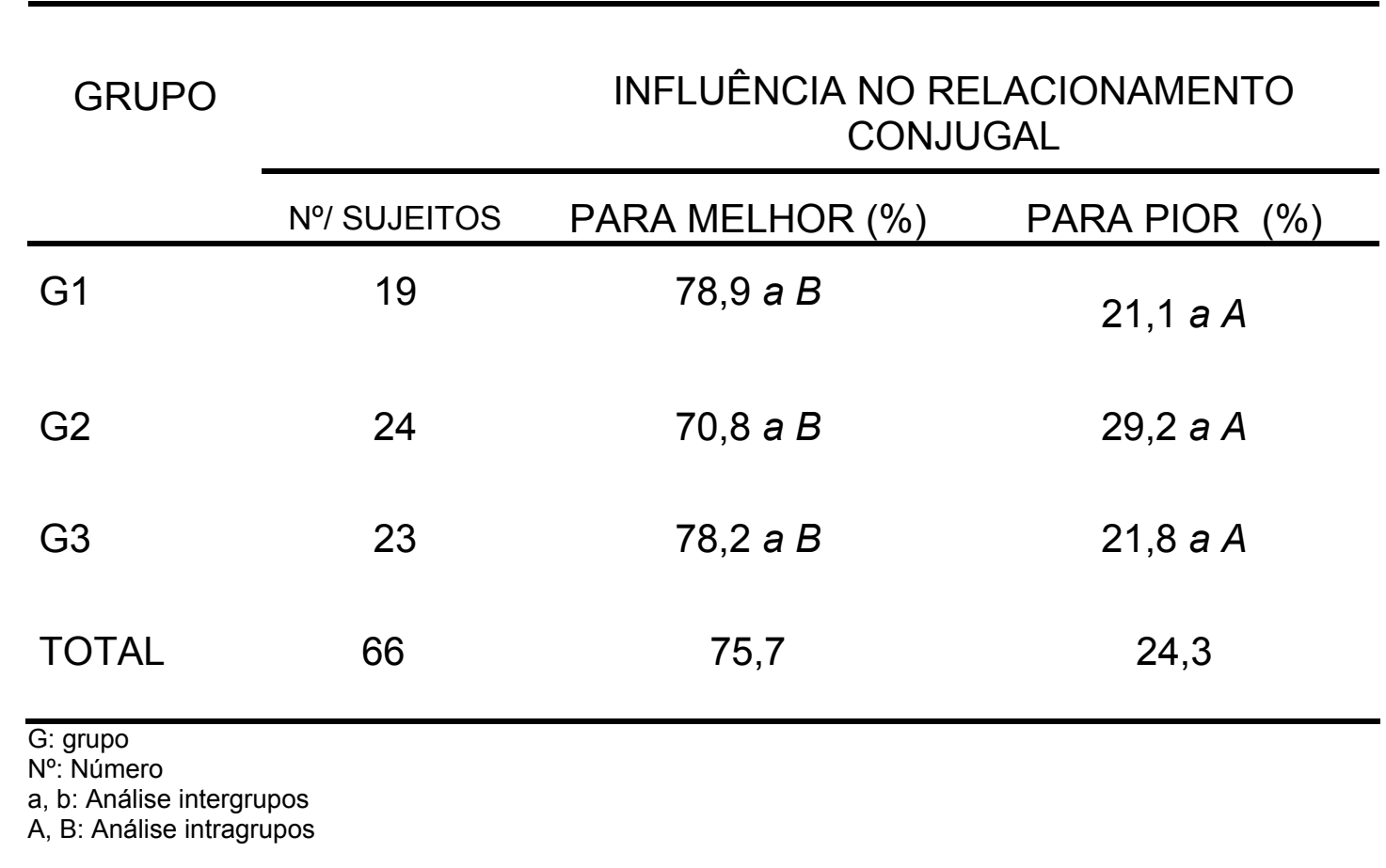

Dos 150 pais participantes, 49 tinham, no momento da coleta de dados, a criança com fissura labiopalatina como filho(a) único(a). Portanto, 101 pais participantes responderam sobre a influência desta fissura no relacionamento entre a criança em questão e os irmãos. Os dados que informam sobre esta influência estão descritos na Tabela 21 e indicam estatisticamente, que na análise intergrupos, os Grupos G2 e G3, quando comparados com o Grupo G1, apresentam uma diferença significativa sobre o não reconhecimento da influência da fissura labiopalatina nos outros filhos. Ressalta-se que na comparação intragrupos, a análise estatística identificou ter o Grupo G1 um reconhecimento significativo, desta influência sobre os outros filhos.

Tabela 21 - Distribuição percentual dos participantes, segundo a percepção destes, sobre a influência da fissura labiopalatina nos outros filhos. 


\begin{tabular}{|c|c|c|c|}
\hline \multirow[t]{2}{*}{ GRUPO } & \multicolumn{3}{|c|}{ INFLUÊNCIA NOS OUTROS FILHOS(\%) } \\
\hline & No/ SUJEITOS & NÃO & SIM \\
\hline \multirow[t]{2}{*}{ G1 } & 25 & & $48,0 b A$ \\
\hline & & 52,0 a $A$ & \\
\hline \multirow[t]{2}{*}{$\mathrm{G} 2$} & 31 & & 19,4 a $A$ \\
\hline & & $80,6 b B$ & \\
\hline \multirow[t]{2}{*}{ G3 } & 45 & & 13,3 a $A$ \\
\hline & & $86,7 b B$ & \\
\hline TOTAL & 101 & 76,3 & 23,7 \\
\hline
\end{tabular}




\section{DISCUSSÃO.}

Quando se fala em fissura labiopalatina, torna-se essencial aprofundarse no sujeito que a experiencia, conhecendo a estreita relação entre a influência da mesma e a sua constituição pessoal, assim como estudar as implicações da mesma para a família e como esse fato pode influenciar as relações estabelecidas dentro desse contexto. O presente trabalho pretendeu descrever e analisar o processo de enfrentamento vivido por pais de crianças com fissura transforame incisivo.

A proposição deste estudo de enfocar os pais dos pacientes com fissura labiopalatina adveio do reconhecimento de ser a família a base vital da constituição de uma pessoa e um eixo significativo no processo de saúde e desenvolvimento físico e mental da criança (Soifer 1982, Minuchin e Fishman 1990, Patterson 1995, Turner et al. 1998, Brito e Dessen 1999). Sendo este, o primeiro grupo social a que pertence o indivíduo, o mesmo the proporciona oportunidades de relacionar-se afetivamente, de aprender e treinar-se em diferentes funções e papéis sociais (Assumpção 1991).

Toda esta forte influência exercida pela família no processo de desenvolvimento de uma criança pode ser compreendida dentro de uma abordagem sistêmica que define este grupo como um sistema, onde todos os seus componentes são interdependentes, onde cada membro da família afeta outro membro e a mudança em um membro causa mudança em todos os outros membros (Minuchin e Fishman 1990, Pinho e Kantorsi 2004). 
Considerando todas estas condições, que naturalmente ficam outorgadas à família, torna-se fundamental um cuidado e uma atenção especial às mesmas, para que se tornem eficientes na influência que exercem sobre suas crianças.

Este estudo entrevistou pais e mães de 150 crianças com fissura transforame incisivo. Os pais participantes foram divididos em três grupos, constituídos pela faixa etária de seus filhos: G1-: 50 pais de pacientes com fissura transforame incisivo não operada, com menos de dois anos de idade; G2-: 50 pais de pacientes com fissura transforame incisivo operada, na faixa etária de seis a oito anos de idade; G3-: 50 pais de pacientes com fissura transforame incisivo operada, na faixa etária de 12 a 15 anos de idade.

A escolha destas faixas etárias se deu, por corresponderem estas, aos períodos mais significativos do desenvolvimento humano: ocasião do nascimento, início da educação formal e adolescência, sugerindo, conseqüentemente, uma reflexão sobre as condições específicas de cada fase.

Autores como Mussem (1974), Bee $(1986,1997)$, Papalia (1981), Aberastury e Knobel (1981), Piletti (1985), Lewis (1993) e Graña (1993), discorrem sobre o tema com admirável pertinência. Para eles, todo o processo de desenvolvimento humano, que acontece de forma gradual e contínua, está diretamente relacionado à constituição de cada família. Este processo se dá em estágios que exprimem novas adaptações. Na faixa etária do zero aos dois anos de idade, toda atividade intelectual é sensorial e motora, ocorrendo sobre o processo de desenvolvimento desta fase, total influência da dinâmica familiar 
e das relações afetivas estabelecidas com os que fazem parte do ambiente da criança.

$\mathrm{Na}$ faixa etária dos seis aos oito anos de idade, os pais continuam a ser fundamentais no processo de desenvolvimento infantil. Concomitantemente, a escola torna-se o foco da vida da criança, ampliando para ela, as vivências afetivo-sociais. Neste período, ela vive a primeira separação da família e, conseqüentemente, a necessidade de ajustamento as regras sociais.

A adolescência refere-se ao período de maiores transformações, tanto no plano físico como no plano psíquico. A família perde parte de seu poder, pois, o grupo de amigos ganha espaço na vida do jovem. $O$ despertar do próprio "eu" e o fortalecimento da identidade possibilitam uma maior independência e autonomia.

Cabe ressaltar que todo e qualquer comprometimento, pode alterar o processo de desenvolvimento. Da mesma forma que, os comprometimentos podem alterar as relações afetivas-sociais, estabelecidas entre pais e filhos, as relações estabelecidas entre esta díade parental, podem influenciar os processos relacionais futuros e mais amplos.

Este comprometimento, que advém de uma malformação congênita, originária no período da oitava semana, refere-se à ausência de fechamento do lábio, do palato e/ou ambos, podendo ser unilateral ou bilateral (Spina et al. 1972, Abyholm 1978, Capelozza e Silva 1992; Silva Filho 1992, Modolin e Cerqueira 1997, Garcia 1997, entre outros).

As fissuras labiopalatais provocam em seu portador graves problemas funcionais, estéticos e psíquicos, acarretando prejuízos de ordem funcional. 
Como também, implicações na família, principalmente nos pais, causadas pelo nascimento de uma criança com fissura labiopalatina, reforçando desta maneira a importância de se realizar estudos que se refiram às relações pais/crianças comprometidas (Souza-Freitas 1974, Minervino-Pereira 2000, entre tantos).

Os dados que identificaram os participantes deste estudo revelaram que as mães predominaram enquanto acompanhantes de seus filhos na situação de tratamento no HRAC, condição esta também observada em outras pesquisas em situações de cuidados com a saúde (Emmel e Matsukura 1989; Davis et al 1998; Pain 1999; Gray 2003; Uzark e Jones 2003; Faver 2005, entre outros). O trabalho de Lam e Mackenzie (2002), revelou um resultado onde a maioria das mães relatou que seus cônjuges mostraram indiferença à criança e não compartilharam as responsabilidades de cuidado. Todavia, cabe ressaltar que não temos dados que indiquem se a ausência dos pais observada, no estudo aqui descrito, se deve aos mesmos motivos.

O estudo de Baumann e Braddick (1999), que trabalhando com pais de crianças com comprometimentos diversos, mostram a importância da paternidade ativa que pode proporcionar melhores qualidades à criança, como segurança, harmonia e amor, facilitando o seu desenvolvimento.

Ressalta-se que em relação ao gênero, o estudo de Gray realizado em 2003, revela que as mulheres são mais vulneráveis do que os homens em situações estressantes e que usam estratégias diferentes das utilizadas pelo gênero masculino no enfrentamento de situações difíceis. O estudo deste autor revelou que, mães têm experimentado graus tão intensos de estresse a ponto 
de desenvolverem doenças físicas, necessitando de medicamentos e de psicoterapia.

Têm-se, também, os trabalhos de Davis et al. (1998) e de Fávero (2005), que investigam a sobrecarga emocional em mães de crianças comprometidas. Os resultados destas pesquisas indicam que a maioria das mães entrevistadas apresentou estresse, depressão e técnicas paliativas de enfrentamento que dificultavam o ajustamento com seus filhos.

Estes dados levam a supostas conclusões sobre uma sobrecarga, que usualmente fica depositada na figura materna no que se refere aos cuidados com filhos comprometidos. Tal condição fica comprovada pela superioridade da presença das mães nos centros reabilitadores, constatada não somente por este estudo, como nas citações literárias referidas.

Os entrevistados eram provenientes, na sua maioria, da região sudeste, provavelmente, devido à maior proximidade com o HRAC e até mesmo pelo fato desse atendimento ter sido descentralizado, acontecendo, atualmente, em outros estados, sob supervisão desse Hospital.

Predominou entre os pais participantes, os casados, pertencentes aos extratos socioeconômicos baixos, com $1^{\circ}$ grau e $2^{\circ}$ grau completos. As condições que identificam os participantes deste estudo refletem o universo desta Instituição, bem como, da realidade brasileira (Graciano et al., 1999),

Em relação á condição socioeconômica, encontrou-se apenas um estudo que fizesse relação entre esta e as condições interacionais de pais com crianças comprometidas. Tal relação foi apresentada no estudo de Holmbeck et al. (2002), que conclui que as famílias, participantes de sua pesquisa, com 
baixo status socioeconômico, demonstraram níveis mais altos de conflito entre a mãe e a criança e menor coesão familiar nos eventos da vida.

Com o propósito de responder aos objetivos específicos deste estudo, serão discutidos os principais resultados as questões colocadas.

Este estudo teve como preocupação inicial investigar, com os pais participantes, a exposição social de seus filhos e a possível existência de dificuldades causadas pela fissura labiopalatina, na vivência de tais situações. Assim considerou-se próprio para faixa etária de zero a dois anos de idade a participação da criança em atividades sociais dos pais. Para a faixa etária de seis a oito anos de idade considerou-se próprio, a freqüência à escola, enquanto que para os que estavam nas idades de 12 a 15 anos considerou-se apropriado uma maior interação e participação em grupos de amigos (Papalia 1981, Aberastury e Knobel 1981, Bee 1986, 1997, Lewis 1993, Graña 1993).

A grande maioria dos pais participantes afirmou não ter problema com relação a esta exposição social. No entanto, observa-se, em relação a esta questão, uma freqüência maior, de modo estatisticamente significante, para o grupo de pais com filhos na idade escolar. Pode-se atribuir, supostamente, este fato, à condição de obrigatoriedade que a sociedade impõe, com relação à participação da criança nesse ambiente. Nos demais casos (enquanto bebê ou na adolescência), há liberdade de escolha, dos pais ou do adolescente, em experienciar ou não, as situações próprias de cada faixa etária previstas por este estudo. O relato destes pais de afirmarem a freqüência de seus filhos nestas situações sociais, é condizente com as respostas dos mesmos, no que se refere a não identificação da influência da fissura labiopalatina no processo 
de interações sociais, respondida, predominantemente pelos participantes. $O$ resultado da pesquisa realizada por Lam e Mackenzie (2002), contraria os achados deste presente estudo, pois, as mães entrevistadas por estes autores, revelaram evitar o contato social.

A condição de facilidade para lidar com a fissura labiopalatina de seus filhos, reconhecida pela maioria dos participantes deste estudo, está também presente no trabalho de Silva e et al. (1999), que encontrou, em pais de crianças com deficiência auditiva, bom desempenho por parte dos mesmos e condições satisfatórias para lidar com situações de estresse. Resultados similares são encontrados também no estudo de Brader (2001), realizado com famílias de indivíduos com anomalias craniofaciais que demonstraram efetivos padrões de adaptação e de estratégias de enfrentamento.

Alguns estudos como os de Souza Freitas (1974), Cariola e Ferreira de Sá (1991), Lazarus e Folkman (1984), Petean e Pina Neto (1998), Maronês (2003) e Rodrigues et al. (2003), consideraram que o nascimento de uma criança com fissura labiopalatina provoca em seus pais conseqüências psicológicas ou mesmo, um choque emocional. Da mesma forma que implicações psicológicas, oriundas das condições de nascimento ou convivência, com uma criança, acompanhada de malformação, desencadeiam nos pais, uma diversidade de sentimentos (Bee 1977, Emmel e Matsukura 1989, Petean e Pina Neto 1998). Estas afirmações justificam e sustentam a investigação deste estudo sobre os sentimentos experienciados pelos pais, nas diferentes fases do desenvolvimento de seus filhos. 
Analisando os relatos que se referem aos sentimentos experienciados pelos participantes de cada grupo, observou-se uma prevalência de identificação com sentimentos positivos sobre os negativos.

Os sentimentos positivos, identificados pelos participantes, que tiveram as maiores freqüências de escolha foram: esperança, atenção, disposição e capacidade.

No entanto, quando se observa especificamente o rol dos sentimentos negativos, o Grupo 1 destaca-se quando comparado com os demais (G2 e G3) na identificação dos mesmos. Os sentimentos negativos mais citados pelos participantes deste grupo foram: medo, insegurança, carência, desespero, desânimo e tristeza.

Apesar da literatura pesquisada demonstrar a condição comum da existência desses sentimentos para a maioria dos pais de crianças com deficiência, podemos inferir que, para os pais de crianças mais novas, se deve a recenticidade do fato. Estes pais podem, ainda, estar sob o impacto causado pelo nascimento de seu filho com fissura labiopalatina. Este ainda não foi operado e, portanto, sua condição pode ser o fator responsável pelos sentimentos negativos relatados. Provavelmente é a primeira vez que estão no hospital e ainda não possuem informações suficientes para amenizar suas emoções. Conseqüentemente, também os pais do Grupo 1, foram os que na identificação dos sentimentos positivos, tiveram uma menor porcentagem de escolha, em relação aos sentimentos de "calma" e "tranqüilidade". Novamente retomamos a inferência de que tal fato pode estar relacionado à faixa etária 
mais nova a que pertencem estes pais e, conseqüentemente, uma maior imaturidade e falta de experiência pessoal.

É interessante notar, que os participantes do Grupo 2, cujos filhos estão na faixa etária que corresponde ao período escolar, foram os que mais se destacaram na identificação com sentimentos positivos, quando comparados com os participantes dos grupos G1 e G3. No entanto, pode-se supor que a superioridade do G2, quando comparado com o G3, seja pelo fato de que os pais dos jovens estejam vivenciando dificuldades próprias do período da adolescência, que não apenas referem-se à existência da fissura labiopalatina ou dos desdobramentos desta. Uma outra inferência que pode ser considerada também em relação a superioridade do G2, deva-se ao momento específico de escolarização de seus filhos. Nesta fase estas crianças têm a oportunidade de se revelarem em muitas habilidades que surpreendem aqueles que só a reconheciam como portadora de um comprometimento.

A literatura considerada neste estudo esclarece que os sentimentos mobilizados nos familiares de crianças com fissuras labiopalatinas não estão descontextualizados, pois numa retrospectiva histórica pôde-se constatar que, desde os primórdios da civilização, a deficiência desorganiza, mobiliza e provoca a condição de estranheza em pessoas não comprometidas (Amiralian 1986).

A vivência de sentimentos negativos provoca, indubitavelmente, uma condição de desconforto a todo ser humano. Da mesma forma que o lidar com o sofrimento e com situações que ultrapassam nossas possibilidades, leva à condição de desequilibro intrapsíquico. Assim a tendência natural do homem é 
buscar formas variadas para lidar com os sentimentos experienciados, formas estas, que se denominam de atitudes de enfrentamento.

Enfrentamento ou coping é um termo usado para descrever qualquer tipo de ação ou comportamento apresentado por uma pessoa, para lidar com um perigo ou inimigo em situações consideradas ameaçadoras, problemáticas ou limitadoras. São estratégias utilizadas para se lidar com situações que signifiquem mudanças, doenças, problemas, dificuldades, estados afetivos desconfortáveis, estresse, entre outros, com a finalidade de eliminá-las, favorecendo, desta forma, a adaptação do ser humano e a superação de suas dificuldades (Lazarus 1966, 1984, Lipowski 1970, White 1974, Mechanic 1976, Schooler 1978, Gimenes 1997, Broder (2001), Pedrolo 2002).

Tais definições propõem que, apenas ações não automáticas e não utilizadas rotineiramente sejam mencionadas sob o termo enfrentamento Portanto, fica claro que o enfrentamento ocorre apenas quando a pessoa não pode se comportar diante das exigências da sua vida da mesma forma como vinha fazendo anteriormente, precisando apresentar novos comportamentos que representam estratégias de enfrentamento.

Podemos considerar que existem atitudes de enfrentamento para lidar com os sentimentos experenciados, que podem ser consideradas como negativas, por não colaborarem com a resolução dos mesmos e por levar a pessoa que os vivencia, à uma maior condição de isolamento, provocada por comportamentos de esquiva ou de fuga. Contrariamente, existem atitudes de enfretamento para lidar com os sentimentos experenciados, que podem ser 
consideradas positivas, por facilitarem a solução e o bem estar de quem os experiencia.

Considerando-se as afirmações acima mencionadas, os participantes deste estudo tiveram a possibilidade, por meio de múltiplas escolhas, de optarem por comportamentos que refletiam às atitudes de enfrentamento utilizadas, para lidar com os sentimentos experienciados, com os quais se identificavam em termos de exposição do filho e na busca de auxilio, nas possíveis redes de apoio, para resolver o problema.

Os dados obtidos possibilitaram a observação que, para os três grupos estudados houve uma identificação, predominantemente maior, das atitudes consideradas positivas sobre as negativas, em todas as fases do desenvolvimento. Analisando as respostas dos participantes que se referem às atitudes de enfretamento consideradas positivas, os Grupos 2 e 3 apresentaram uma identificação maior que o Grupo 1 em relação a estas.

No estudo realizado por Broder (2001), também existiu a conclusão que, tanto as pessoas com anomalias craniofaciais como suas famílias, apresentavam efetivos padrões adaptativos e estratégias enfrentamento que facilitavam melhorar a qualidade de vida.

Um olhar mais específico para os resultados que se referem às atitudes de enfrentamento, pode revelar que o grupo de pais de crianças com fissura transforame ainda não operada (Grupo 1), teve uma maior identificação que os outros dois grupos estudados, nas atitudes consideradas negativas. Tal fato sugere que, o medo do julgamento externo, a existência do estigma e a dificuldade ainda intensa, de lidar com esta situação, fizeram com que esses 
pais tivessem atitudes de enfrentamento de maior evitação social, condição esta também muito comum, em alguns estudos citados neste trabalho, como o de Lam e Mackenzie (2002), que se referiram ao preconceito existente na sociedade chinesa, em aceitar pessoas com comprometimentos.

Vale mencionar que nos estudos realizados por Taanila et al. (2002), as atitudes de enfretamento denominadas por esta pesquisa de positivas e/ou negativas, foram denominadas de atitudes de elevado enfrentamento e de baixo enfrentamento, respectivamente. Estes autores concluíram que as famílias que utilizavam atitudes de elevado enfrentamento eram melhores sucedidas do que as outras, no processo de resolução de problemas.

Para o enfrentamento de vivências consideradas difíceis, delicadas e estressantes, usualmente o ser humano, na condição de ser social, procura auxílio em fontes diversas. Assim, este estudo possibilitou aos participantes indicações múltiplas de ajuda, que foram denominadas de redes de apoio.

Para a análise da possível rede de apoio utilizada por estes pais, as opções foram incluídas dentro das categorias: busca de apoio do tipo individual e busca de apoio do tipo coletivo. A categoria individual refere-se a comportamentos que envolvam a iniciativa individual e a autonomia pessoal de resolução do proposto. A categoria coletiva envolve, além da tomada de decisão, a disponibilidade de terceiros e/ou a existência de recursos externos.

Considerando-se as redes de apoio do tipo individual, pode-se observar que as opções "vivência religiosa, a busca de informações com profissionais, leituras específicas e procura de todo o tipo de apoio" tiveram porcentagens superiores à opção "sair para passear", para todos os grupos 
estudados. Ressalta-se que esta última foi a opção de menor porcentagem para os pais entrevistados.

A realização de uma análise comparativa entre os dados obtidos referentes às atitudes de enfrentamento e as possíveis redes de apoio utilizadas principalmente pelos participantes do G1, demonstra uma coerência interna dos mesmos. Pois, na condição deste grupo utilizar atitudes de enfrentamento negativas, que se referem primordialmente a comportamentos de evitação de situações sociais, em maior freqüência que os Grupos 2 e 3, faz conseqüentemente, que se dirijam a redes de apoio que se caracterizem por uma iniciativa individual e isolada (religiosidade, busca de informações com profissionais e leituras específicas).

Coincidentemente, o estudo realizado por Shaver (1993) afirmou que, freqüentemente, pais se sentem e são isolados de amigos e parentes.

Quanto à rede de apoio considerada do tipo coletivo, os resultados indicaram que os Grupos 2 e 3 se identificaram em maior freqüência com as opções "contar com o apoio do cônjuge e dos filhos" e "contar com o apoio de familiares em geral". A opção que se refere à condição de "não fazer nada de especial" foi uma escolha indicada apenas pelos participantes do Grupo 1. Este mesmo grupo apresentou porcentagens inferiores aos outros dois grupos na maioria das opções oferecidas. No entanto, no que se refere à opção de "busca de apoio com familiares em geral" o G1 foi o grupo que indicou maior preferência para este tipo de suporte.

Torna-se necessário tecer-se algumas reflexões sobre os dados referidos no parágrafo acima. Como foi dito anteriormente, o nascimento de 
uma criança com comprometimentos, pode provocar em seus pais um choque emocional que leva à experienciação de reações diversificadas que transitam entre sentimentos de culpa, vergonha, rejeição, tristeza, entre tantos. O impacto do nascimento também provoca nestes pais, vivências que se caracterizam por fases denominadas de: negação, luto, negociação, para se chegar e a aceitação. Todas estas são reações à dor, portanto inevitáveis (Emmel e Matsukura 1989, Cariola e Ferreira e Sá 1991, Shaver 1993, Cavalcante 2001, entre outros). O Grupo 1, pais de crianças na faixa etária de zero a dois anos de idade, com fissura transforame ainda não operada foi o único grupo, dos três grupos estudados, que se identificou com a condição de não fazer nada especial diante da fissura labiopalatina. De acordo com estes autores, podemos inferir que estes pais, pela situação inicial de contato com a fissura labiopalatina, podem estar vivendo neste momento um estado de choque, que Ihes coloca numa situação de letargia, imobilizados que estão, pela dor experienciada. Carvalho e Tavano (2000), realizaram um estudo com pais de crianças que iniciavam o processo de reabilitação no HRAC e obtiveram os dados que também se reportavam a uma condição de passividade vivida por eles. Lam e Mackenzie (2002) afirmaram que mães com filhos na faixa etária de zero a seis meses utilizam estratégias de enfrentamento focalizadas na emoção e na negação.

O fato dos participantes deste estudo terem se identificado com o apoio do tipo coletivo, que se refere que se refere a "contar com a ajuda de familiares", coincide com os estudos realizados por Bradbury e Hewison (1964), Cavalcante (2001) e por Salles (2002) que consideraram o suporte da 
família como uma variável significativa que facilitava o processo de ajustamento total ao nascimento de uma criança com fissura labiopalatina congênita de palato, anomalias craniofaciais e deficiência auditiva. Este mesmo dado também sugere a inferência de que, a maior identificação do G1 por este tipo de apoio, pode estar relacionado com faixa etária dos pais deste grupo $(<20 / 29)$, que sugere uma maior imaturidade e falta de experiência, levando-os a uma maior busca de apoio com seus progenitores.

Faz-se importante também, considerações à respeito do significado e da importância do apoio, para pais de crianças que apresentam dificuldades e/ou comprometimentos. Especificamente, todo tipo de apoio, seja ele individual ou coletivo, pode ser um "pára-choque" efetivo contra a tensão e isolamento enfrentado por esta população. Apoio social é um construto que se refere à contribuição do ambiente social para o bem-estar. Mães com níveis de apoio sociais fortes têm possibilidades de usar uma gama mais extensa de estratégias que as mães com mais baixos níveis de apoio social, conforme reconheceu também, o estudo realizado por Sank et al. (2003).

De forma similar, as relações entre os membros familiares, a coesão da família e os sentimentos de união e cooperação com o cônjuge e os outros filhos foram reconhecidos como muito importantes no processo de enfrentamento, como afirmam Taanila et al. (2202), quando reconhecem estarem todos os membros familiares afetados pelo nascimento de uma criança com invalidez.

O apoio informal dos amigos e parentes, também pode ser considerado extremamente válido para se administrar a vida cotidiana. 
A vivência religiosa, citada pelos participantes deste estudo como uma significativa rede de apoio, pode ser definida como afiliação organizacional ou freqüência de igreja, assim como: fator de convicção pessoal, fé, esperança. A religião não só oferece um sistema de enfrentamento, apoio social e valores pessoais, mas também, uma fundação de convicção pessoal e familiar que afeta aspectos da vida diária. O sistema das práticas religiosas específicas e 0 apoio social da comunidade da igreja oferecem um recurso de enfrentamento para a vida diária. Os resultados deste estudo validam o poder da religião e o significado espiritual para lidar com o desafio potencial de criar uma criança com inaptidões. Entre estas famílias, o apoio positivo da religião foi o que mais prevaleceu. Marshall et al (2003) realizaram um estudo para identificar a influência da religiosidade na adaptação e na convivência de familiares com uma criança com inaptidões. O estudo destes autores enfatizou a importância de tal prática, como sendo extremamente reconfortante.

Entre os achados do estudo de Rodrigues et al. (2003), também se encontrou a referência sobre a importância da ajuda divina no processo de enfrentamento vivido por pais na ocasião de diagnóstico da fissura labiopalatal de seus filhos.

Ficou evidenciado que o maior benefício, em termos de rede de apoio individual, para o enfrentamento de situações de se lidar com a criança com fissura transforame foi a busca de informações com profissionais e a existência de leituras específicas. Os pais consideraram ajuda e o apoio dos sistemas de serviços formais como muito importantes e, particularmente, encorajadores e úteis. Pode-se considerar que a informação adequada sobre o diagnóstico da 
criança e sobre o tratamento, facilitam o controle do estresse, pois, permitem uma perspectiva realística da inaptidão da criança promovendo uma maior aceitação da situação e uma atitude otimista para o futuro da criança.

As colocações feitas em relação à importância das informações profissionais são condizentes e validadas pelo estudo de Pain (1999), Lam e Mackenzie (2002), Taanila et al. (2002) e de Trulsson e Klingberg (2003), que concluíram sobre a utilidade das mesmas por facilitarem o processo de ajuste emocional dos pais de crianças comprometidas e aliviarem a condição de estresse causado nas famílias.

Estudos como o de Kerr et al. (2000) indicam a validade e a importância dos pais poderem compartilhar e comparar as suas experiências com as de outros pais que estão em uma situação semelhante. Para estes autores, segundo a pesquisa que realizaram, o contato entre pais de crianças comprometidas foi considerado como o tipo de ajuda e de apoio mais adequados. No entanto, esta vivência de universalidade parece não ter entre os participantes deste estudo um reconhecimento maior como uma rede de apoio que favoreça o processo de enfrentamento vivido por estes pais. Ainda na nossa realidade a participação em grupos de apoio não é considerada uma prática comum e de grande significado.

Este estudo considerou que as atitudes de enfrentamento pudessem ser determinadas por fatores que se denominavam como internos e/ou externos. Maturidade, religiosidade e comodismo foram considerados como determinantes internos; enquanto que, incentivos, valores familiares e 
atendimentos realizados no HRAC, foram incluídos como sendo determinantes externos.

Em relação às escolhas de identificação com os determinantes internos e/ou externos, estudados de acordo com a análise estatística, os três grupos não apresentaram diferenciação entre si no que se refere ao total nas duas categorias de respostas, sendo suas escolhas similares em todas as opções apresentadas. Contanto que, a maioria dos participantes dos três grupos estudados, na categoria de determinantes internos, elegeu a maturidade e a religiosidade como sendo responsáveis na sustentação de suas atitudes de enfrentamento. Fica também conclusivo e irrefutável para este estudo, a importância reconhecida ao atendimento prestado pelos profissionais do HRAC, bem como o incentivo da família e dos amigos (determinantes externos), como facilitadores do processo de enfrentamento.

A partir de uma abordagem sistêmica da família, este estudo teve a preocupação de identificar a influência da fissura labiopalatina na relação familiar. A maioria dos participantes reconheceu ter esta fissura influenciado o relacionamento familiar. As diferenças entre os grupos, ainda que pequenas, mostraram que o reconhecimento desta influencia foi maior para os Grupos 1 e 3. Entre aqueles que reconheceram esta influência, a identificação desta como para pior ao relacionamento familiar, superou o reconhecimento da influência da fissura labiopalatina como um elemento favorável. No entanto, somente para os participantes do Grupo 1 que este reconhecimento desfavorável aconteceu de forma estatisticamente significante. 
Considerando que a existência de um membro do sistema familiar com comprometimento, altera a homeostase da dinâmica do grupo, pelas demandas e implicações do mesmo, os dados que confirmam a influência da fissura como desfavorável ao relacionamento familiar podem indicar que o nível de estresse imposto a todos os membros deste sistema, seja um dos responsáveis por tal condição. Os estudos de Davis et al. (1998) e Uzark e Jones (2003), revelaram que o desajuste familiar, a angústia dos pais estão muito mais associados com os níveis de estresse do que com a severidade do comprometimento, da mesma maneira que o estudo de Trute e Hiebert -Murphy (2002) que, avaliando o impacto da presença de uma criança deficiente na família, previu um estresse futuro de longa duração.

Buscando identificar se houve ou não influência da fissura labiopalatina no relacionamento conjugal, os participantes dos três grupos estudados, que se encontravam na condição civil de casados no momento da entrevista, não se diferenciaram estatisticamente entre si em suas respostas. Entretanto, para os que reconheceram a existência desta influência, as respostas que indicaram uma condição de melhoria no relacionamento conjugal foram estatisticamente superiores daqueles que a identificaram como comprometedora da relação conjugal. O estudo realizado por Cariola e Ferreira de Sá (1991) coincide com o resultado desta presente pesquisa, pois, também ele identificou uma maior porcentagem no reconhecimento melhoria no relacionamento do casal após o nascimento do filho com fissura labiopalatina.

O trabalho de Lam e Mackenzie (2002), revelou um resultado que contraria os achados deste presente estudo. Em relação aos efeitos do 
comprometimento dos filhos, no relacionamento conjugal, a maioria das mães relatou que havia uma condição de piora deste relacionamento.

O subsistema filial também se mobiliza quando existem intercorrências no âmbito familiar. Assim sendo, filhos não fissurados podem sofrer a influência da fissura labiopalatina quando esta acontece em seus irmãos, por mobilizar cuidados e atenção especial por parte dos pais, resultando em alterações na dinâmica familiar. Considerando a possibilidade da influência da fissura labiopalatina nos filhos não comprometidos, os participantes dos Grupos 2 e 3, quando comparados com o Grupo 1, apresentaram uma diferença significativa, referente ao não reconhecimento desta influência, nos outros filhos. Ressalta-se que na comparação intragrupos, a análise estatística identificou ter o Grupo 1 um reconhecimento significativo, da influência da fissura labiopalatina sobre os outros filhos. Esta análise sugere, duas interpretações: em primeiro lugar, provavelmente, as crianças mais novas (Grupo 1) apresentam uma maior demanda de cuidados e intervenções, acabando por monopolizar uma dedicação e atenção por parte dos pais; em segundo lugar, existe uma grande probabilidade destes pais, por sua vez, estarem envolvidos com a fragilidade emocional própria desse momento e, conseqüentemente, com menor disponibilidade interna para atender aos outros filhos, ressentindo-os. As crianças mais velhas (G2 e G3) por estarem em fases mais adiantadas do processo de reabilitação e, também, por possuírem uma maior independência e autonomia, no que se refere a cuidados pessoais e vivências sociais, são menos exigentes de cuidado parental, resultando em menos dificuldades na convivência com seus irmãos não fissurados. 
Como afirmam Lam e Mackenzie (2002), os pais de crianças comprometidas, dedicam um tempo bem maior que o usual, no cuidado destas. A responsabilidade que lhes cabe em relação à sua saúde, incluindo principalmente, a freqüência em programas de reabilitação e as demandas próprias da rotina diária Ihes causam tensão e lhes exigem paciência, comprometendo-os em seus outros relacionamentos.

Como considerações finais, pode-se afirmar que os resultados obtidos nesse estudo demonstram diferenças nas formas de enfrentamento utilizadas por pais de crianças com fissuras transforame, nas diferentes idades. Todavia, observou-se que o Grupo 1 está mais suscetível ao momento que estão vivendo, uma vez que apresentam mais sentimentos negativos com relação à condição da sua criança, do que os participantes dos demais grupos.

Pelo fato de reconhecerem a importância dos serviços oferecidos à eles pelo HRAC, este pode ser enriquecido ainda mais, com o apoio psicológico oferecido sistematicamente, neste período. Ações bem sucedidas poderão resultar em famílias mais adaptadas nas fases seguintes, além de torná-las promotoras do desenvolvimento das crianças, de forma mais efetiva.

Também, deve ser tratada com muito cuidado, a questão das informações, nessa primeira fase do processo de reabilitação. O volume de informações, ainda que extremamente necessário, parece não garantir sua absorção por parte dos pais. Considerando-se que estão vivendo o momento inicial de contato com a fissura labiopalatina, supõe-se um maior envolvimento com uma diversidade de sentimentos, o que Ihes dificulta a apreensão das 
informações oferecidas. Isso sugere a necessidade de se viabilizar esta compreensão e a garantia de que os pais as retiveram.

Um dos pontos importantes, que este estudo pode oferecer como sugestão, é assegurar que os profissionais considerem os benefícios potenciais do apoio de pai-para-pai promovendo contatos entre eles, logo após o nascimento da criança comprometida e durante todo o período de reabilitação. Essa atitude pode resultar em encorajamento e desenvolvimento de atividades de apoio para famílias, facilitando o processo de reabilitação da criança com fissura lapiopalatina. 


\section{CONCLUSÕES.}

A análise dos resultados deste estudo permitiu concluir que:

Os pais participantes deste estudo favorecem a participação de seus filhos nas vivências consideradas próprias de suas faixas etárias, não identificando a fissura labiopalatina como uma condição de influência em tais situações.

Considerando o rol de sentimentos experenciados por estes pais, nas situações acima mencionadas, para a maioria dos três grupos estudados, verificou-se um predomínio de sentimentos positivos sobre os negativos. Ressaltando que, apesar desta predominância ter acontecido, o Grupo 1, foi o que, entre os grupos estudados, apresentou menor identificação com estes sentimentos.

Quanto às atitudes de enfrentamento, utilizadas pelos participantes, comprovou-se que os Grupos 1, 2 e 3 tiveram semelhança na identificação com as opções consideradas do tipo positivas e/ou negativas. Destaca-se que as atitudes de enfrentamento positivas prevaleceram para todos os grupos estudados. Evidencia-se que o Grupo 1 tem valores menores que os outros dois grupos para a maioria das opções que foram consideradas como positivas.

Em relação às redes de apoio elegidas por estes participantes, que facilitariam a vivência de enfrentamento das situações consideradas difíceis e delicadas, entre as denominadas do tipo individual, as mais relatadas foram vivência religiosa e busca de informações e, entre as redes de apoio consideradas coletivas observou-se a presença de apoio familiar, pelos participantes dos três grupos estudados. 
Na similaridade de respostas obtidas pelos participantes dos Grupos 1 , 2 e 3 quanto aos fatores que determinaram suas atitudes de enfrentamento, as consideradas do tipo externo, foram as que mais se destacaram para estes três grupos. Chama atenção a escolha "atendimento dos profissionais do Centrinho" pelo elevado índice de identificação pelos três grupos entrevistados.

Finalmente, em relação à influência da fissura labiopalatina na relação familiar como um todo, este estudo constatou ser a mesma existente, de modo desfavorável ao relacionamento, principalmente para os integrantes do Grupo 1. No entanto, ao que se refere à influência da fissura labiopalatina sobre o relacionamento conjugal, de forma estatisticamente significante, esta influência foi percebida, como para melhor para os três grupos. Apesar de os participantes dos Grupos 1, 2 e 3 não identificarem a influência da fissura labiopalatina na vida dos outros filhos não fissurados, esta negação, estatisticamente significativa, só aconteceu para os Grupos 2 e 3.

Os resultados obtidos nesse estudo mostram que há poucas diferenças nas formas de enfrentamento utilizadas por pais de crianças com fissuras transforame nas diferentes idades. Todavia, observou-se que o Grupo 1 está mais suscetível ao momento que estão vivendo, uma vez que apresentam mais sentimentos negativos com relação à condição da sua criança do que os participantes dos demais grupos. Como conseqüência, apresentam estratégias de enfrentamento do tipo negativo e individual, com desdobramentos nos efeitos sobre os outros filhos não fissurados.

Os dados obtidos sugerem o investimento de ações junto aos pais, no início da sua história com seu filho fissurado, de forma a possibilitar um 
relacionamento familiar sadio que favoreça o desenvolvimento bio-psico-social da criança com fissura labiopalatina. 


\section{Referências Bibliográficas.}

Aberastury A, Knobel M. Adolescência normal. Porto Alegre: Artes Médicas; 1981.

Åbyholm FE. Cleft lip and palate in norwegian population. II. A numerical study of 1555 CLP - patients admitted for surgical treatment. Scand J Plast Reconstr Surg 1978. 12:35-43.

Amiralian MLTM. Psicologia do excepcional. São Paulo:EPU,1986.

Amaral AS, Genaro KF. Análise da fala em indivíduos com fissura lábiopalatina operada. Pró-Fono 1996. 8:36-46.

Assumpção Júnior, FB. Sprovieri MH. Introdução ao estudo da deficiência mental. São Paulo: Memnon; 1991.

Baumann SL, Braddick M. Out of their element: fathers of children who are "not the same". J Pediatr Nurs 1999. 14:369-78.

Bee H. A criança em desenvolvimento. 3a. ed. São Paulo: Harbra; 1986.

Bee H. A Criança em desenvolvimento. São Paulo: Harper, Raw do Brasil; 1997.

Bertier CE, Machado Neto JS, Montagnolli LC. Tratamento cirúrgico da fissura labial unilateral. In: Carreirão S, Lessa S, Zanini SA. Tratamento das fissuras palatinas. 2a. ed. Rio de Janeiro: Revinter; 1996. p. 67-75.

Bradbury ET, Hewison J. Early parental adjustment to visible congenital disfigurement. Child Care, Health Dev 1994. 20:251-66. 
Bradley D. Congenital and acquired velopharyngeal inadequacy. In: Bzoch KR, editor. Communicative disorders related to cleft lip and palate. 4th. Ed. Texas: Pro-Ed; 1997. p. 223-43.

Brito AMW, Dessen MA. Crianças surdas e suas famílias: um panorama geral. Psicol Reflex Crit 1999. 12:1-13.

Broder HL. Using psychological assessment and therapeutic strategies to enhance well-being. Cleft Palate Cranifac J 2001. 38:248-254.

Capelozza Filho L, Silva Filho OG. Fissuras lábio-palatais. In: Petrelli E, coordenador Ortodontia para fonoaudiologia. Curitiba: Lovise; 1992. p. 196-39.

Cariola TC, Sá AEF. Atitudes e reações emocionais de pais com o nascimento de uma criança portadora de fissura labiopalatal. Pediatr Mod 1991. 46:489494.

Carreirão S, Silva MO. Conceitos atuais do tratamento cirúrgico da fissura palatina In: Carreirão S, Lessa S, Zanini, SA. Tratamento da fissuras palatina. 2a. ed. Rio de Janeiro: Revinter; 1996. p.173-79

Carvalho APB, Tavano LD. Avaliação dos pais diante do nascimento e tratamento dos filhos portadores de fissura labiopalatal, no Hospital de Reabilitação de Anomalias Craniofaciais da Universidade de São Paulo Bauru. Pediat Mod 2000. 36:842-47.

Cavalcante F. Family, subjectivity and language: the "abnormal" child grammar. Ciênc Saúde Coletiva 2001. 6:125-37.

Cerqueira ATAR. O conceito e metodologia de coping: existe consenso e necessidade? In Kerbauy RS, organizadora. Comportamento e cognição: 
conceitos, pesquisa e aplicação, a ênfase no ensinar, na emoção e no questionamento clínico. Santo André: SET; 2000. v.5 p.34:279-89.

Davis CC, Brown RT, Bakerman R, Campbell R. Psychological adaptation and adjustment of mothers of children with congenital heart disease: stress, coping, and family functioning. J Pediatr Psychol 1998. 23:219-28.

Emmel MLG, Matsukura TS. Grupo-suporte de mães de crianças em atendimento em terapia ocupacional. Psicol Teor e Pesqui 1989. 5:315-23.

Fávero MAB. Trajetória e sobrecarga emocional da família de crianças autistas: relatos maternos [dissertação]. Ribeirão Preto: Faculdade de Filosofia Ciências e Letras de Ribeirão Preto; 2005.

Folkman S, Lazarus RS. An analysis of coping in a middle-aged community sample. J Health Soc Behav 1980. 21:219-39.

Fraser FC. Some experimental and clinical studies on the causes of congenital clefts of the palate and the lip. Arch Pediatr 1960. 77:151-6.

Fraser FC. The genetics of cleft lip and palate. Am J Hum Genet 1970. 22:33652.

Garcia JRL. Auto-imagem em pacientes adultos com fissura lábio-palatal: uma análise através do desenho da figura humana [Monografia]. Bauru: Hospital de Pesquisa e Reabilitação de Lesões Lábio-Palatais, Universidade de São Paulo. 1997.

Gimenes MGG. A teoria do enfrentamento e suas implicações para sucessos e insucessos em psiconcologia. In: Gimenes MGG, Fávero MH, organizadores. A mulher e o câncer. Campinas: Psy, 1997. p. 111-47. 
Gimenes, MGG. A pesquisa do enfrentamento na prática psico-oncológica. In Carvalho MM,organizador. Introdução à psicooncologia. Campinas: Psy; 2000. p. 232-46.

Goodman LA. Simultaneous confidence intervals for contrasts among multinomial populations. Annals of Mathematical Statistics; 1964. 2:716-25.

Goodman LA. On simultaneous confidence intervals for multinomial proportions. Technometrics; 1965. 2:247-54.

Gomes PRM, Mélega JM. Tratamento cirúrgico. In: Altmann EBC, organizador. Fissuras labiopalatinas. 4a. ed. Carapicuiba: Pró-Fono; 1997. p. $61-72$.

Graña RB. Técnica psicoterápica na adolescência. Porto alegre: Artes Médicas; 1993.

Gray DE. Gender and coping: the parents of children whit high functioning autism. Soc Sci Med 2003. 56:631-642.

Greene JC. Epidemiologic study of cleft lip and cleft palate in four states. J Am Dent Assoc 1964. 68:387-04.

Greene JC. Epidemiologic research: 1964-1967. J Am Dent Assoc 1968. 76:1350-6.

Holmbeck GN, Coakley RM, Hommeyer JS, Shapera WE, Westhoven VC. Observed and perceived dyadic and systemic functioning in families of preadolescents whit spina bifida. J Pediatr Psychol 2002. 27:177-89. 
Iregbulem LM. The incidence of cleft lip and palate in Nigeria. Cleft Palate $J$ 1982. 9:201-5.

Janis IL, Mann L. Emergency decision making: a theoretical analysis of responses to disaster warnings. J Hum Stress 1977. 3:35-45.

Johnson PE. Surgical repair of cleft lip and palate. In: Pirruccelo FW, editor. Cleft lip and palate. Springfield: Charles C. Thomas;1987. p. 69-00.

Kerr SM \& Mclntosh JB. Coping when a child has a disability: exploring the impact of parent-to-parent support. Chil: Care Health Dev 2000. 26:309-22.

Lam L, Mackenzie, AE. Coping with a child with down syndrome: the experiences of mothers in Hong Kong. Qualif Health Res 2002. 12: 223-37.

Lazarus, RS. Psychological stressand the coping process. New York: McGrawHill; 1966.

Lazarus R, Folkman S. Estrés y procesos cognitivos. Barcelona: Martinez Roca; 1984.

Lewis M, Volkman F. Aspectos clinicos do desenvovimento na infância e na adolescência. Porto Alegre: Artes Médicas. 1993.

Lipowski ZJ. Physical illness, the individual and the coping processes. Psychiatry Med 1970. 1:91-102.

Maronês L, Corrês TC, Yamada MO. The impact and management of parents of patients with hearing impairment. Pediatr Mod 2003. 39:464-65. 
Marshall ES, Olsen SF, Mandleco BL, Dyches TT, Allred KW, Sansom N. This is a spiritual experience": perspectives of Latter-Day Saint families living whit a child whit disabilities. Qualit Health Res 2003. 13:57-76.

Mechanic D. Stress, illness and illness behavior. Human Stress 1976 2:2-6.

Minervino-Pereira ACM. Auto conceito e auto estima em indivíduos com fissura lábio-palatina: influência do tipo de fissura e do tempo de convivência com a mesma [dissertação]. Bauru: Hospital de Reabilitação de Anomalias Craniofaciais da Universidade de São Paulo; 2000.

Minuchin S, Fishman HC. Técnicas de terapia familiar. Porto Alegre: Artes Médicas. 1990.

Modolin MLA, Cerqueira EMM. Etiopatogenia. In: Altmann EBC, organizadora, Fissuras labiopalatinas. 4a. ed, Carapicuíba: Pró-Fono; 1997. p. 25-30.

Mussen $\mathrm{PH}$, Conger JJ, Kagan J. Desenvolvimento e personalidade da criança. 4a. ed. São Paulo: Harbra; 1974.

Nagem Filho H, Moraes N, Rocha RGF. Contribuição para o estudo da prevalência das más formações congênitas lábio-palatais na população escolar de Bauru. Rev Fac Odont São Paulo 1968. 6: 111-28.

Natsume N, Suzuki T, Aoki K, Makino S, Mizutani J, Kawai T. Epidemiologic studies on cleft lip and/or palate. I. The classification of cleft types in the general population. Aichi Gakuin Daigaku Shiga 1984. 22:455-60.

Neel JV. A study of major congenital defects in japanese infants. Am J Hum Genet 1958. 10: 398-45. 
Norman GR, Streiner,D.L. Bioestatísties - The bare essentials. Mosby Year Book 1994.

Pain $\mathrm{H}$. Coping with a child with disabilities from the parents' perspective: the function of information. Child: Care Health Development 1999. 25:299-12.

Papalia D, Olds SW. O mundo da criança: da infância à adolescência. São Paulo: McGraw-Hill do Brasil,1981.

Patterson JM. Promoting resilience in families experiencing stress. Pediatric Clinics of North America:;1995. 42 47-63.

Pedrolo FT. O enfrentamento dos familiares à imagem corporal alterada do laringectomizado. Revista Brasileira de Cancerologia. 2002. 48:49-56.

Pereira ACMM, Mota SAS. Análise da influência do estigma físico nas relações interpessoais em indivíduos com malformações craniofaciais: fissura lábiopalatina. Mimeses 1997. 18:143-54.

Petean EB, Pina Neto JM. Investigations in genetics counseling: the impact of first notification - parental reaction to a deficiency. Medicina, 1998. 31: 288-95.

Piletti N. Psicologia educacional. 2a. ed. São Paulo: Ática; 1985.

Pinho LB, Kantorski LP, Reflectioning about the families psychosocial contex of patients in the emergency. Cienc e Enferm 2004. 10:67-77.

Rodríguez OPMR, Lopes AA, Zuliane G, Marques LC, Combinato DS. Pais de bebês com anomalias craniofaciais: análise das reações após o nascimento e atualmente; In: Marquezine MC, Almeida MA, Omote S, Tanaka EDO, 
organizadores. O papel da família junto ao portador de necessidades especiais. Londrina: Eduel; 2003. p. 15-22.

Romero E. As dimensões da vida humana: existência e experiência. São José dos Campos: Novos Horizontes; 1998.

Salles RA, Faria MEB, Graciano MIG. Família: base para a (re) habilitação profissional do deficiente auditivo. Constr Serv Soc 2002. 10:139-57.

Sank JR, Berk NW, Cooper ME, Marazita ML. Perceveid social support of mothers of chidren whit clefts. Cleft Palate Craniofacl J 2003. 40:165-71.

Savoia MG. Escalas de eventos vitais e de estratégias de enfrentamento (coping). Rev Psiquiatr Clin 1999. 26:57-63.

Shaver T. Reações dos pais ao nascimento de uma criança com deficiência severa. Mensagem da APAE, 1993. p. 8-11.

Silva SC, Krom M, Bevilacqua MC, Yamada MO. Família da criança deficiente auditiva: características e recursos Pró-Fono 1999. 11:47-52.

Silva Filho OG, Ferrarini Junior FM, Rocha DL, Souza Freitas JA. Classificação das fissuras lábio-palatais: breve histórico, considerações clínicas e sugestão de modificação. Rev Bras Cirurg 1992. 82:59-65.

Soifer R. Psicodinamismo da família com crianças: terapia familiar com técnica de jogo. Petrópolis: Vozes, 1982.

Spina V, Psilakisn JM, Lapa FS, Ferreira MC. Classificação das fissuras lábio palatais: sugestões de modificação. Rev Hosp Clin Fac Med, São Paulo 1972. 27:5-6. 
Souza Freitas JA. Centro de Pesquisa e Reabilitação de Lesões LábioPalatais. Bauru: Centro de Pesquisa e Reabilitação de Lesões Lábio-Palatais da faculdade de Odontologia de Bauru da Universidade de São Paulo. 1974.

Strickland BR. Internal-external expectancies and health-related behaviors. $J$ Consult Clin Psychol 1978. 46:1192-211.

Taanila A, Syrjala L, Kokkonen J, Jarvelin MR. Coping of parents with phyically and /or intellectually disabled chidren. Child Care, Health Devt 2002. 28:73-86.

Trulsson U, Klingberg G. Living with a child with a severe orofacial handicap: experiences from the perspectives of parents. Eur J Oral Sci 2003. 111:19-25.

Trute B, Hiebert-Murphy D. Famifly adjustment to childhood developmental possibility: a measure of parent appraisal of family impacts. J Pediatr Psychol 2002. 27:271-280. Eur Ort Soc 1998; 20:407-15.

Turner SR, Rumsey N, Sandy JR. Psychological aspects of cleft lip and palate.

Uzark K, Jones K. Parenting stress and children with heart disease. J Pediatr Health Care 2003. 17:163-68.

White RW. Strategies of adaptation: an attenpt at systematic description. In: Hamburg GV, Adams JE, editores. Coping and adaptation. New York: Basic Books. 1974. 
Anexo 1- Protocolo de Entrevista

\section{UNIVERSIDADE SÃO PAULO \\ HOSPITAL DE REABILITAÇÃO DE ANOMALIAS CRANIOFACIAIS}

\section{O PROCESSO DE ENFRENTAMENTO VIVIDO POR PAIS DE INDIVÍDUOS COM FISSURA}

LÁBIOPALATINA, NAS DIFERENTES FASES DO DESENVOLVIMENTO

Grupo: 1- $\square$ não operado ( 0 a 2 anos)

2- $\square$ fase escolar ( 6 a 8 anos)

Ficha $n^{\circ}$

3- $\square$ adolescência (12 a 15 anos)

A) CARACTERIZAÇÃO DO SUJEITO:

1) Identificação do paciente

Nome: RG.

Sexo: 1-M 2-F

$\mathrm{DN}$ :

Idade: anos

Estado Civil: ........ 1-Solteiro 2-Casado

2) Identificação do entrevistado

Nome:

RG:

Sexo:

1-M 2-F

$\mathrm{DN}:$...../...../....

Idade: .anos

Estado Civil: . 1-Solteiro 2-Casado

3-Viúvo

4-Separado

3) Procedência: Cidade:

UF

4) Escolaridade: 1- Sem instruções

2- $1^{\circ}$ grau incompleto

3-1 $1^{\circ}$ grau completo

4- $2^{\circ}$ grau incompleto

5- $2^{\circ}$ grau completo

6-3grau incompleto

7- $3^{\circ}$ grau completo

5) Nivel sócio econômico:

( )N/C ( )F-BI ( )E-BS ( )D-MI ( )C-M ( )B-MS ( )A-AL

6) Na vivência da situação de: $\square$ nascimento de seu filho com fissura

$$
\begin{aligned}
& \square \text { ingresso regular na escola (alfabetização) } \\
& \square \text { início da adolescência } \\
& \square \text { inserção no mercado de trabalho e/ou faculdade }
\end{aligned}
$$

B) ENTREVISTA DE ENFRENTAMENTO:

1) 1.Seu filho sai com vocês para todos os lugares? $\square$ Sim $\square$ Não

2. Seu filho freqüenta a escola? $\square \operatorname{Sim} \square$ Não

(escola)

3. Seu filho já sai sozinho, com grupo de amigos? $\square$ Sim $\square$ Não $\quad$ (adolescência)

4. Seu filho trabalha? $\square \operatorname{Sim} \square$ Não $\quad$ (trabalho) 
2.O fato de ser fissurado dificultou esta experiência para ele? $\square \operatorname{Sim} \square$ Não

3. Quais os sentimentos que você experencia/experenciou nesta fase?

$\begin{array}{lll}\square \text { 1.indiferença } & \square \text { 11.tolerância } & \square \text { 21.pessimismo } \\ \square \text { 2.tranqüilidade } & \square \text { 12.medo } & \square \text { 22.alegria } \\ \square \text { 3.tristeza } & \square \text { 13.intolerância } & \square \text { 23.disposição } \\ \square \text { 4.solidão } & \square \text { 14.incapacidade } & \square \text { 24.atenção } \\ \square \text { 5.calma } & \square \text { 15.carência } & \square \text { 25.capacidade } \\ \square \text { 6.raiva } & \square \text { 16.culpa } & \square \text { 26.desespero } \\ \square \text { 7.fracasso } & \square \text { 17.confiança } & \square \text { 27.orgulho } \\ \square \text { 8.insegurança } & \square \text { 18.otimismo } & \square \text { 28.apoio } \\ \square \text { 9.vergonha } & \square \text { 19.coragem } & \square \text { 29.conforto } \\ \square \text { 10.esperança } & \square \text { 20.desânimo } & \square \text { 30.solidariedade }\end{array}$

4) Como você lida (ou lidou) com estes sentimentos?

$\square$ me isolando de tudo e de todos

$\square$ evitando reuniões familiares

$\square$ evitando reuniões sociais (igreja, festas, praças, shopping, etc)

$\square$ não evitando reuniões familiares

$\square$ não evitando reuniões sociais (igreja, festas, praças, shopping, etc)

$\square$ buscando familiares e amigos

$\square$ evitando levar a criança em locais de pessoais estranhas

$\square$ continuando a fazer tudo o que normalmente fazia

5) O que vocêfaz (ou fez) para enfrentar as suas dificuldades e sentimentos?

$\square$ vivência religiosa

$\square$ saio muito para passear

$\square$ busco informações com profissionais e leitura específicas

$\square$ procuro todo tipo de apoio

$\square$ nunca fiz nada de especial

$\square$ faço parte de grupos de apoio

$\square$ conto com o apoio da minha família (marido, outros filhos, etc)

$\square$ conto com o apoio da minha família (meus pais, irmãos, pais e irmãos do meu marido,etc)

6)A que você atribui esta sua forma de pensar ou de se comportar?

$\square$ maturidade

$\square$ imaturidade

$\square$ religiosidade

$\square$ comodismo

$\square$ valores familiares

$\square$ incentivo da família e ou amigos

$\square$ ao atendimento dos profissionais do Centrinho 
7) A presença desta deficiência (ou mal formação) de seu filho afeta (ou afetou) a sua familia?

Sim............ Não...

Como

8) Afetou o seu relacionamento conjugal?

Sim.

Não.

Como

9) Acha que afetou seus filhos?

Sim

Não.

Como 
Anexo 2- Aprovação pelo Comitê de Ética em Pesquisa em Seres Humanos do Projeto de Pesquisa denominado: "O processo de enfrentamento vivido por pais de indivíduos com fissura labiopalatina, nas diferentes fases do desenvolvimento". 
Anexo 3- Termo de consentimento livre e esclarecido

\section{"TERMO DE CONSENTIMENTO LIVRE E ESCLARECIDO"}

$\mathrm{Eu}$,

Portador de RG $\mathrm{n}^{\circ}$ residente à Rua (AV). $\mathrm{N}^{\mathrm{o}}$ na cidade de Estado

responsavel por matriculado no HRAC com o $\mathrm{N}^{\mathrm{o}}$ concordo em participar da pesquisa de Título: "O processo de enfrentamento vivido por pais de indivíduos portadores de fissura LABIOPALATINA, nas diferentes fases do desenvolvimento", realizada por: Ana Cristina Musa Minervino Pereira, $\mathrm{N}^{\circ}$ do Conselho sob a orientação do Dr. José Alberto de Souza Freitas, $N^{0}$ do Conselho

A referida pesquisa tem como objetivo conhecer, descrever e analisar o processo de enfrentamento de pais de pessoas portadoras de fissura lábiopalatina, em alguns períodos do desenvolvimento humano: por ocasião do nascimento, no inicio da educação formal e na adolescência.

Fui orientado que caberá a cada participante responder à uma entrevista semiestruturada, realizada individualmente em condições de privacidade Algumas das questões desta entrevista serão adaptadas para cada grupo considerando-se a faixa etária e o processo de desenvolvimento.

A referida pesquisa proporcionará à família do paciente acometido de fissura lábiopalatina, benefícios que poderão facilitar sua reabilitação emocional e sua integração familiar e social.

$\mathrm{Eu}$ entendo que qualquer informação obtida sobre mim será confidencial. Eu também entendo que meus registros de pesquisa estão disponíveis para revisão dos pesquisadores. Esclareceram-me que minha identidade não será revelada em nenhuma publicação desta pesquisa; por conseguinte, consinto na publicação para propósitos científicos.

Estou ciente também de que estou livre para recusar minha participação neste estudo ou para desistir a qualquer momento e que a minha decisão não afetará adversamente o tratamento de meu filho no HRAC ou causar perda de benefícios para os quais eu poderei ser indicado.

Eu certifico que li ou foi-me lido o texto de consentimento e entendi seu conteúdo. Minha assinatura demonstra que concordei livremente em participar deste estudo.

Assinatura do participante da pesquisa:

Data:

Pesquisador Responsável: Ana Cristina Musa Minervino Pereira

Endereço Institucional: R. Sílvio Marchione, 3-20 Bauru/SP cep. 17.043-900

Telefone: 32358000 - Ramal: 8232 
Anexo 4 - Ficha do Serviço Social. 